University of Louisville

ThinkIR: The University of Louisville's Institutional Repository

Electronic Theses and Dissertations

8-2014

\title{
The effectiveness of extended orientation first year seminars : a systematic review and meta-analysis.
}

Matthew S. Berry

University of Louisville

Follow this and additional works at: https://ir.library.louisville.edu/etd

Part of the Education Commons

\section{Recommended Citation}

Berry, Matthew S., "The effectiveness of extended orientation first year seminars : a systematic review and meta-analysis." (2014). Electronic Theses and Dissertations. Paper 105.

https://doi.org/10.18297/etd/105

This Doctoral Dissertation is brought to you for free and open access by ThinkIR: The University of Louisville's Institutional Repository. It has been accepted for inclusion in Electronic Theses and Dissertations by an authorized administrator of ThinkIR: The University of Louisville's Institutional Repository. This title appears here courtesy of the author, who has retained all other copyrights. For more information, please contact thinkir@louisville.edu. 
THE EFFECTIVENESS OF EXTENDED ORIENTATION FIRST YEAR SEMINARS: A SYSTEMATIC REVIEW AND META-ANALYSIS

\author{
By \\ Matthew S. Berry \\ B.A., Wittenberg University, 2006 \\ M.S., Benedictine University, 2011 \\ A Dissertation \\ Submitted to the Faculty of the \\ College of Education \& Human Development of the University of Louisville \\ in Partial Fulfillment of the Requirements \\ for the Degree of \\ Doctor of Philosophy \\ Department of Leadership, Foundations \& Human Resource Education \\ University of Louisville \\ Louisville, Kentucky
}

August, 2014 

THE EFFECTIVENESS OF EXTENDED ORIENTATION FIRST YEAR SEMINARS: A SYSTEMATIC REVIEW AND META-ANALYSIS

\author{
By \\ Matthew S. Berry \\ B.A., Wittenberg University, 2006 \\ M.S., Benedictine University, 2011 \\ A Dissertation Defense Approved on
}

July 2, 2014

by the following Dissertation Committee:

Jeffrey Valentine, Dissertation Director

Jacob Gross, Dissertation Co-Director

Beth Bukoski

Bridgette Pregliasco 


\section{DEDICATION}

This dissertation is dedicated to Leshy. 


\section{ACKNOWLEDGEMENTS}

I love teams. I always have. There is nothing better to me than working as hard as possible toward a common goal with a dedicated group of self-sacrificing people. Unfortunately, I have been told time and time again, writing a dissertation is a lonely process. For me, this was gladly not the case. This has been a team event and any success I have had in this endeavor has been due to the extraordinary talents and generosity of the people that surround me. While I have received support from countless friends and family during this process I would like to specifically acknowledge a few members of my team without whom this accomplishment would not have been possible.

First, I would like to thank the members of my committee for the support and challenges they provided me. It was an honor to perform a meta-analysis under the tutelage of Dr. Jeff Valentine and a pleasure to get to know him for the patient, goodhearted teacher that he is. I thank Dr. Jacob Gross for being with me every single step of the way these past three years and for teaching me what it means to be a mentor in every sense of the word. I am grateful to Dr. Bridgette Pregliasco for striking the perfect balance of challenge and support and for always reminding me of my audience. Thank you, Dr. Beth Bukoski for asking me to think of things in new ways by forcing me out of my quantitative comfort zone and for somehow always sensing when a word or two of simple comfort were needed. I am eternally grateful to these four people for investing the amount of time and energy into this project that they did. I promise to pay it forward. 
Finally, I would also like to thank by office buddy, Dr. Devon Twyford. It was a long journey and I'm glad we got to make it together.

I wish to express my thanks and love to my Mom, Dad, and big brother for a list of things too long to include here. All three of you were "non-traditional" college students and understanding the guts and grit it took each of you to get where you are made all the long days and late nights working on this project seem just a little easier. Like we do with everything else in our family you all made this goal seem important without letting me take myself too seriously. Thanks for all the love and laughs. Thanks to my in-laws as well for supporting me wholeheartedly and for never seeming to doubt that I really did have to miss out on family events because I was "working on my dissertation." Finally, thanks to my best friend and wife, Alecia for taking every single step of this journey with me. As with most of the best things in my life this couldn't and wouldn't have happened without you. There is no question in my mind that I didn't do this; we did this. 


\title{
ABSTRACT \\ THE EFFECTIVENESS OF EXTENDED ORIENTATION FIRST YEAR SEMINARS: A SYSTEMATIC REVIEW AND META-ANALYSIS
}

\author{
Matthew S Berry
}

July 2, 2014

Previous research has shown that while nearly $40 \%$ of all students who enter postsecondary institutions leave without ever obtaining a degree, nearly two-thirds of students who persist to their second year eventually obtain a degree. Given the impact of the first year, a multitude of initiatives designed to promote first-to-second year persistence developed. The most popular initiative has been the first year seminar and particularly the extended orientation model of first year seminar. Given its prominence in the undergraduate curriculum, a large body of research has developed in recent decades investigating the first year seminar. However, the predominance of this literature has been conducted as single institution studies thus limiting the generalizability of previous findings. Therefore, in this study I used a systematic review and meta-analysis to move beyond information provided by single institution studies and gain a broader understanding of the overall effectiveness of extended orientation first year seminars.

The results indicated that voluntary participation in an extended orientation first year seminar had a statistically significant, positive effect on first term GPA, first year GPA, and first-to-second year retention. For each of these three outcomes, a significant degree of heterogeneity was observed between study effect size estimates. Moderator 
tests did not identify patterns in this heterogeneity but did indicate that, for the first term GPA outcome, courses taught by faculty as opposed to teams of faculty and staff or staff alone were associated with larger effect sizes. Also, for the retention outcome, samples comprised of less than $75 \%$ White students yielded larger effects than did samples with greater than $75 \%$ white students. The implications of these findings for university administrators are also discussed along with suggestions for future research. 


\section{TABLE OF CONTENTS}

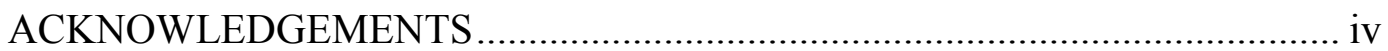

ABSTRACT ...................................................................................... vi

LIST OF TABLES .............................................................................

LIST OF FIGURES ......................................................................... xiii

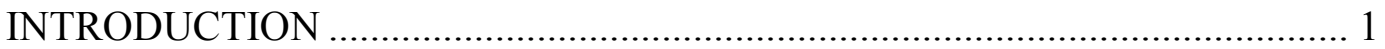

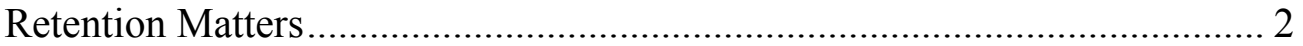

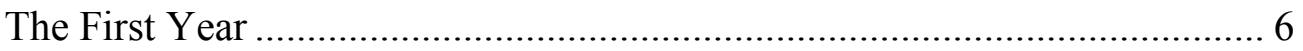

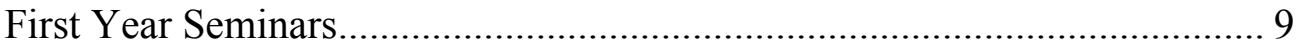

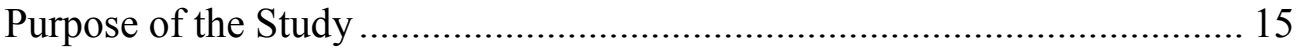

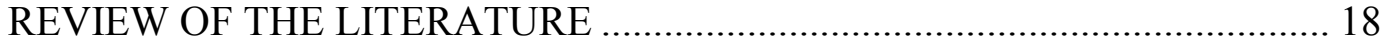

College Student Retention ........................................................................ 19

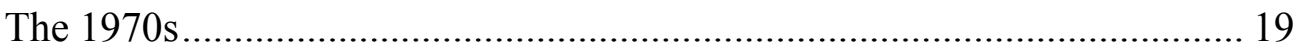

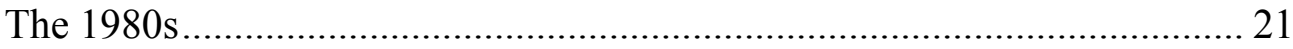

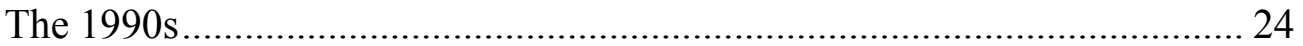

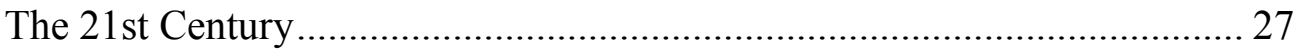

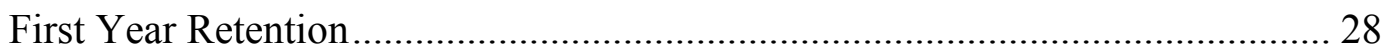


Changing Demographics

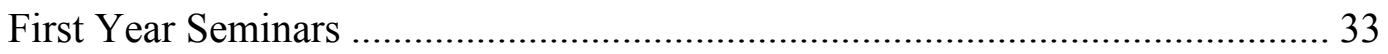

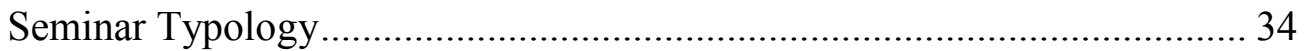

Extended Orientation Seminars ............................................................ 37

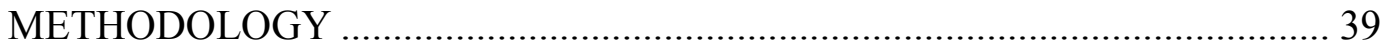

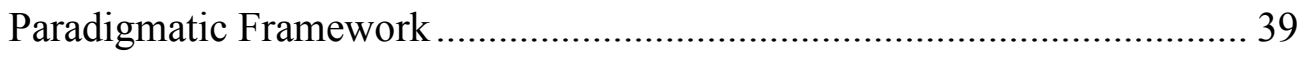

Study Inclusion Criteria ................................................................... 41

Literature Search Strategy ................................................................... 42

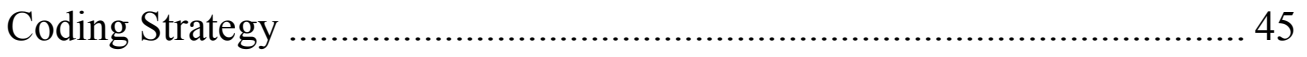

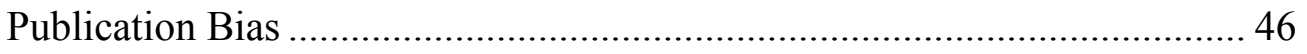

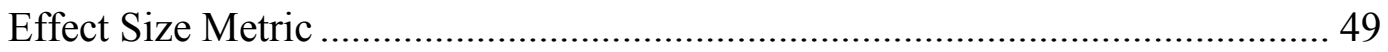

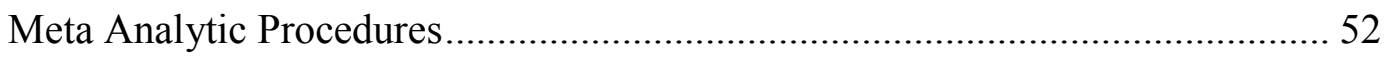

Weighted Effect Size ................................................................... 53

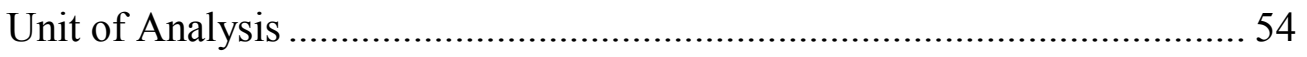

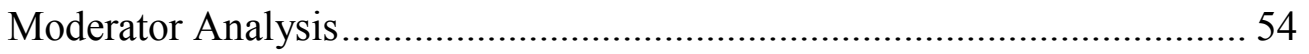

Fixed Vs. Random Effects ............................................................. 56

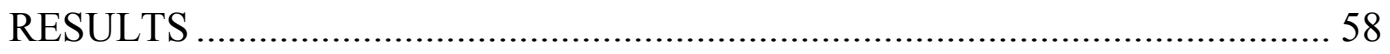

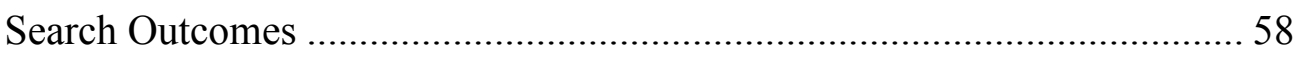

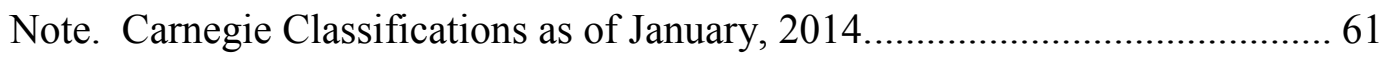

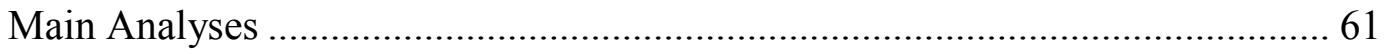


Meta-Analysis One: First Term GPA

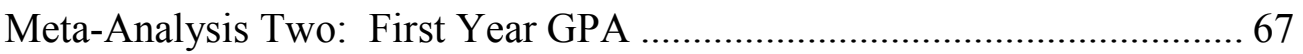

Meta-Analysis Three: First-to-Second Year Retention ........................... 73

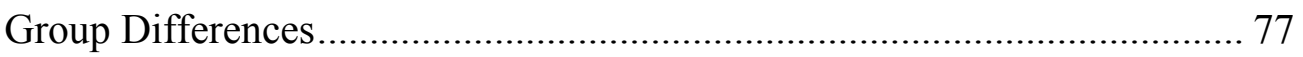

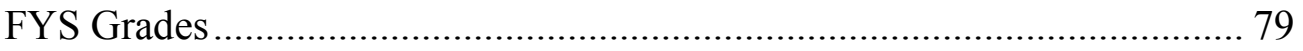

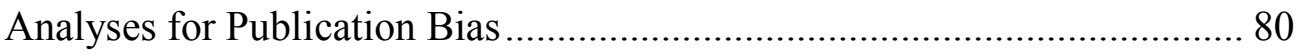

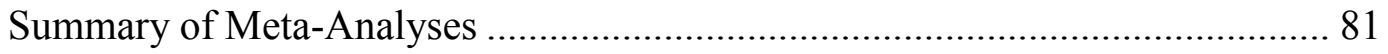

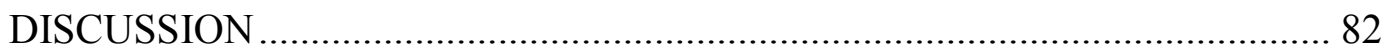

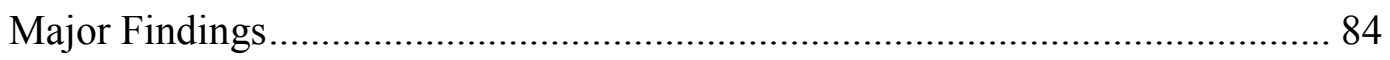

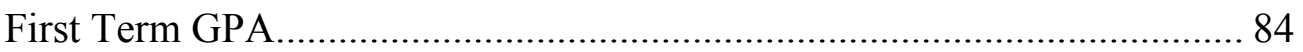

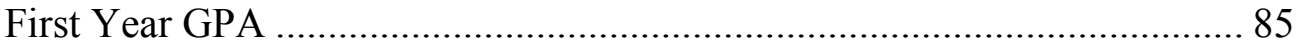

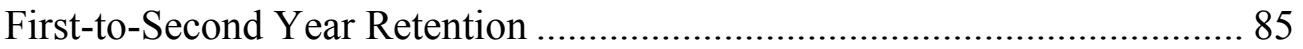

Moderators …................................................................................ 86

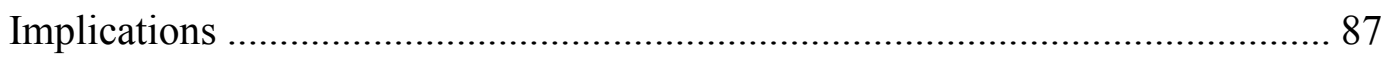

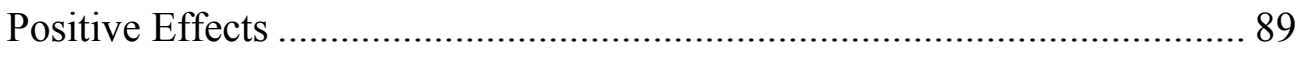

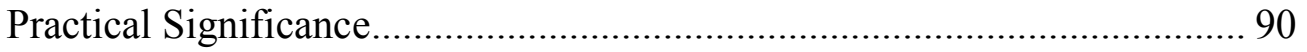

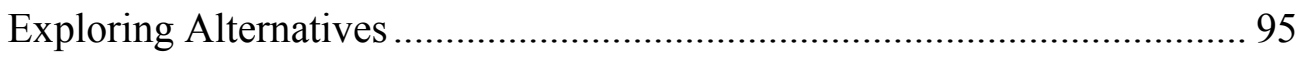

Limitations \& Directions for Future Research ............................................ 97

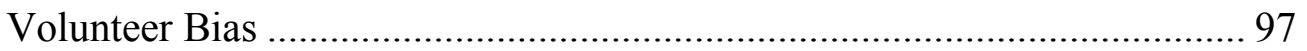

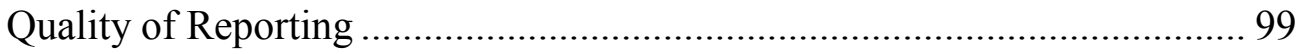


Scope and Scale 100

Study Design . 101

Mixed Methods 102

Conclusion 104

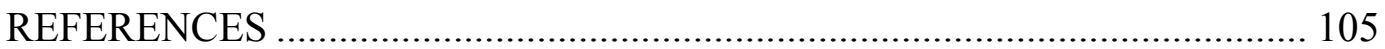

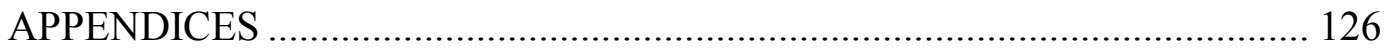

Appendix A - Screening Coding Guide …………....................................... 126

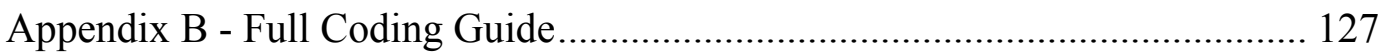

Appendix C - Study Request Protocol ............................................................... 137

Appendix D - Group Comparability …………………............................. 138

Appendix D - Moderator Table ...................................................................... 140

Appendix F - Studies Included in Meta-Analytic Samples ................................ 142

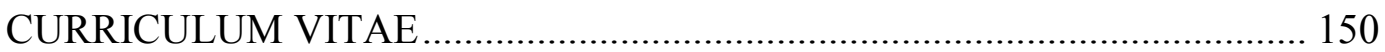




\section{LIST OF TABLES}

TABLE

PAGE

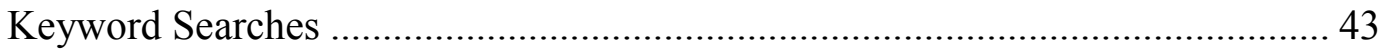

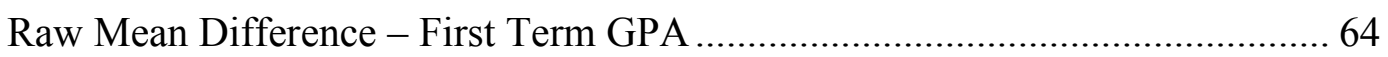

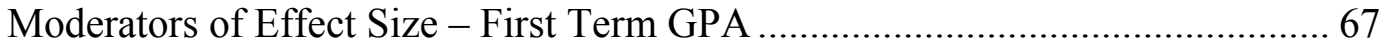

Raw Mean Difference - First Year GPA .................................................. 70

Moderators of Effect Size - First Year GPA ….............................................. 72

Log Odds Ratio - First -to-Second Year Retention ........................................ 75

Moderators of Effect Size - First-to-Second Year Retention ............................ 76

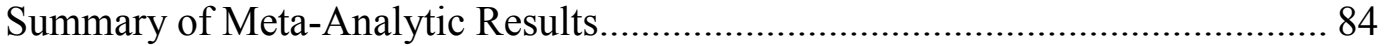

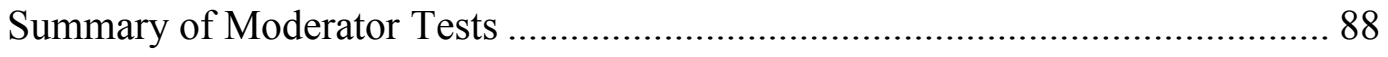




\section{LIST OF FIGURES}

FIGURE PAGE

Figure 1 Trim \& Fill - First Term GPA …..................................................... 123

Figure 2 Trim \& Fill - First Year GPA ..................................................... 124

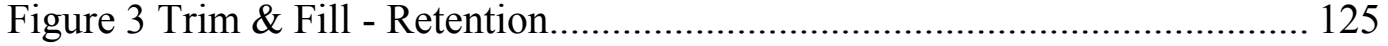




\section{CHAPTER I}

\section{INTRODUCTION}

Student retention has been recognized as American higher education's primary goal as well as its greatest challenge (Reason, 2009). The difficulty of retaining students has been highlighted by decades of troubling rates of retention and graduation. Since 1983 five-year graduation rates at four-year colleges and universities have ranged from a low of $50.9 \%$ in 2001 to a high of $55.1 \%$ in 1989 . In 2013 just below $53 \%$ of students at four-year institutions had graduated within five years. During the same thirty year period two-year colleges and universities showed similar sluggishness with 3-year attainment rates ranging from a low of $25.5 \%$ in 2012 to a high of $38.8 \%$ in 1989 (ACT, 2013). In total, approximately $40 \%$ of students at every level of higher education leave their college without obtaining a degree (Tinto, 1993).

Decades of research has investigated college student retention in an attempt to better understand student departure behavior (Braxton, 2000; Boden, 2012). Though no clear solutions have come to light through this work, perhaps the clearest theme to emerge is the significance of the first year of college. Since 1983 first-to-second-year retention rates for four-year colleges and universities have ranged from $72.3 \%$ in 2008 to $74.9 \%$ in 1991 and from $51.3 \%$ in 2004 to $55.7 \%$ in 2012 for two-year institutions (ACT, 2013). Tinto (1993) placed these numbers into context through the assertion that "the largest proportion of institutional leaving occurs in the first year and prior to the beginning of the second year," (p. 14). Terenzini (1987) helped to further underscore the 
relationship between the first year, retention, and graduation by stating that at least $50 \%$ of the overall dropout rate can be accounted for by freshman leaving at the end of the first year of study. It seems clear then that first-to-second year persistence has a direct impact on long-term persistence and the likelihood of eventual degree-attainment. While national five-year graduation rates have hovered near 50\% for decades, among students who do persist to their second year, about two-thirds complete a degree (Stratton, O’Toole, Wetzel, 2008). Given this impact, "the first year is of particular importance to the continued discourse on college student retention in American higher education," (Kuep, 2006, p. 62).

\section{Retention Matters}

The benefits of degree attainment have become nearly undeniable. A college degree has largely supplanted the high school diploma as the educational credential most needed for economic self-sufficiency and productive citizenship. Earning a bachelor's degree has been linked to cognitive, social and economic benefits (Kiser \& Price, 2008). These benefits are often passed to younger generations increasing opportunities for productive citizenship and by extension enhancing society at large (Kuh, Cruce, Shoup, Kinzie, Gonyea, 2008). It is these increased opportunities that are amongst the principal motivations for improving rates of retention and graduation (Delen, 2012). The Institute for Higher Education Policy (IHEP) categorized the benefits of postsecondary degree attainment into four groups. First, public economic benefits include increased tax revenues, worker productivity, a larger consumer base, and a decreased reliance on government financial support. Next, private economic benefits encompass higher salaries, lower unemployment, improved working conditions, and professional mobility. 
Public social benefits include reduction in crime, increased civic action, and a greater appreciation for diversity. Finally, private social benefits such as improved health, higher quality of life, and a longer life span have all been linked to postsecondary degree attainment (The Investment Payoff: A 50-State Analysis of the Public and Private Benefits of Higher Education, 2005).

Perhaps the clearest advantage of student persistence and degree attainment is seen in terms of individual economic prosperity. In 2011, for example, the median salary of bachelor's degree holders was $\$ 21,100$ higher than those who held no higher than a high school diploma. This income gap widens as individuals progress through their careers. Amongst full-time workers aged $25-29$, bachelor's degree holders earn 54\% more than high school graduates. For those between $45-49$ years of age, this disparity grows to 86\% (Education Pays: The benefits of higher education for individuals and society, 2013). Similarly, associate's degree holders earn an average median salary 31.2\% greater than do high school graduates (The Economic Benefits of Postsecondary Degrees, 2012). Those who attain a postsecondary degree not only earn more but also see lower levels of unemployment. In 2012, for example, the unemployment rate for four-year college graduates was $7.1 \%$ below that of high school graduates while associates degree-holders were 4.0 percentage points below high school graduates. Finally, during a 40-year working life, the median earnings of those with associate's degrees are $27 \%$ higher than those with a high school degree. Bachelor's degree holders will, on average, have $65 \%$ higher median earnings than high school graduates (Education Pays, 2013). Over the course of a career this means that, on average, associate's degree holders earn about $\$ 400,000$ more than high school graduates while 
those with a bachelor's degree can expect an average of $\$ 1$ million more in lifetime earnings than their counterparts who hold a high school degree (The College Payoff: Education, Occupations, Lifetime Earnings, 2009).

The impact of retention does not limit itself to the individual. Many, if not most, of the institutions losing students are heavily dependent upon tuition revenue. The loss of students equates to the loss of key revenue for colleges and universities. Not only are tuition dollars lost but other key sources of revenue such as room and board and other fees are also no longer collected. To combat these losses institutional resources are often rerouted from other priorities (Kiser \& Price, 2008). Recruitment, for example, is often used as a way of stemming the financial impact of student attrition. Strategies such as this, however, require significant institutional expenditures; often without a clear benefit. It can take 3-5 times more money to recruit a new student than it does to retain a current student (Cuseo, 2010). Further, according to Hossler and Bean (1990), a student who is retained at an institution for four years will generate the same revenue as will four new students who leave after one year. In addition to the immediate fiscal impact, losing current students also means losing a base of future potential income. Students who are not retained by an institution are less likely to become future financial donors (Jamelske, 2008) or to recommend the institution to future prospective students (Cuseo, 2010). Therefore, the issue of student retention is one of immediate and long-term financial concern for postsecondary institutions.

Aside from the financial impact that student departure can have, the reputation and perceived effectiveness of postsecondary institutions is at stake as well. Retention and graduation rates have long been used as a proxy for the successes and failures of 
educational efforts. Further, these measures are seen as a gauge of what future performance might look like (Copeland \& Levesque-Bristol, 2011). Key stakeholders view student outcomes as a measure of the quality of postsecondary education institutions. Public and political pressures for greater efficiency and effectiveness on the part of higher education have increased during the past decade and given rise to a new college completion agenda. This focus was intensified by the Obama administration's espousal of the 2020 goal to have the highest proportion of college graduates in the world (College Graduation: Behind the Numbers, 2010). Therefore, in the current landscape of American higher education, retaining and graduating students is perhaps as critical to the perceived success of institutions as it is to the individual.

Not just individuals and institutions but "all of society benefits when more people have college educations," (Cunningham, 2006, p. 1). Individuals with postsecondary degrees not only contribute more, on average, to the tax and consumer base but also tend to be healthier, rely less on government social programming, are less likely to be incarcerated in their lifetimes, and generally engage more frequently in pro-social civic behavior (Cunningham, 2006). Postsecondary education is also positively correlated with civic behaviors such as voting, attending public meetings, and running for public office (Malveaux, 2003). 42\% of adults with a four year degree report volunteering in some capacity as compared to $17 \%$ of those with a high school degree. Furthermore, in 2012, $12 \%$ of high school graduates 25 and older lived in households that were enrolled in the Supplemental Nutritional Assistance Program (SNAP) compared to just $2 \%$ of those with at least a bachelor's degree (Education Pays, 2013). Research has also shown that those who persist to degree attainment display more open and critical thinking patterns, higher 
levels of involvement in political and social activities, more willingness to participate in community service, and a greater openness to issues related to racial and cultural diversity. While postsecondary education cannot be credited as the sole reason for these behaviors it is clear that those who have the opportunity to attend and graduate from institutions of higher education have greater access to resources which assist them in developing into productive and engaged citizens (Cunningham, 2006).

Not only is the retention and graduation of students essential to the mission of higher education, then, but there are tangible advantages as well. Institutions and their students enjoy clear social and economic benefits from high rates of degree attainment. Subsequently, if retaining students to their second year vastly improves the chances of retention through to graduation (Stratton, et al., 2008) then the first-to-second year retention of undergraduate students is among the most important issues in American higher education. Given the impact of navigating the first year it is little wonder that, as Pascarella and Terenzini (2005) point out, "studies of first- to second- year persistence dominate this literature."

\section{The First Year}

The task of retaining students into their second year has proven difficult largely as a byproduct of the unique issues present in the first year of college. The first year is a time of transition marked by obstacles impeding social and academic integration into the college environment (Crissman, 2002). Students must deal with issues such as choosing a major, navigating a higher level curriculum, managing time effectively, and forming new relationships with faculty, staff and fellow students (Gardner, 2001). Traditionally aged first-year students may also face a substantial identity role shift from adolescence 
toward adulthood. Many freshmen are confronted with a new level of independence and face physical and psychological separation from family and past social and peer support groups. These realities can make the first year especially difficult for those who may also be faced with "significant stressors such as acculturation issues, financial strain, adjustment, and/or emotional problems," (Hanger, Goldenson, Weinberg, SchmitzSciborski, Monzon, 2012). These challenges, along with those which may be unique to the individual, are all confronted as a part of the ongoing decision-making process of whether to stay at an institution, to drop out, stop out, or to transfer (Andrade, 2008).

The challenges of the first year of college have translated into consistently high levels of student departure. In the ten year period between 1992 and 2002, for example, first-to-second year retention rates for all four-year institutions ranged from a high of $74.8 \%$ in 1992 to a low of $73.1 \%$ in 1996 (ACT, 2013). In 2004 this rate had fallen to $68.3 \%$ (ACT, 2005) and in 2013 just over 65\% of students returned to their original institution for their second year (ACT, 2013b). Overall, in the thirty year period between 1983 and 2013 the first-to-second year retention rate for all colleges and universities in the United States was $65.8 \%$ (ACT, 2013).

In response to empirical and theoretical findings highlighting the unique nature of the first year there has been wide recognition of the need for concentrated efforts to ease the transition from high school to college (Adrande, 2008; Soldner, Lee, Duby, 1999; Dill, Gilbert, Hill, Minchew, Sempier, 2011). Curricular and co-curricular interventions have taken many forms but have typically shared the common goals of promoting academic success, social integration, and ultimately retaining students. Other common objectives of first year interventions include increasing student-to-student interaction, 
faculty-to-student interaction outside of class, increasing student involvement and time on campus, linking the curriculum and co-curriculum, increasing academic expectations, promoting engagement, and assisting academically underprepared students in their transition (Barefoot, 2000). These efforts have been labeled with the moniker of First Year Experience (FYE) programs (Soldner, et al., 1999). FYE programs can include learning communities, orientation programs, student development interventions, course support initiatives and first-year seminars (Andrade, 2008). Others initiatives include peer advising and mentoring networks, campus-sponsored "Welcome" activities, workshops and tutorials, residence life programming, and a plethora of other interventions (Kuep, 2006).

There are three forms of first-year interventions which have taken prominence in the overall FYE movement. The first of these are service learning programs. These programs characterized by the inclusion of service activities that are tied to a classroom experience and used to promote campus and civic engagement amongst students (Kuep, 2006). Next are learning communities. While many definitions exist, the core of a learning community involves curricular structures that encourage broader understanding of material through the integration of similar themes across courses and within groups of students (Knight, 2003). Cross (1998) defined learning communities as "groups of people engaged in intellectual interaction for the purpose of learning," (p. 4). Finally, and given its prominence, perhaps most importantly, are first year seminars. First year seminars (FYS) are most often small, discussion based courses in which curricular and co-curricular exchanges between students and faculty are designed to assist in the academic and social integration into college life (Kuep, 2006). Among all first year 
interventions first year seminars stand alone in their pervasiveness as a tool designed to promote the first-to-second year retention of undergraduate students.

\section{First Year Seminars}

The pervasive nature of freshman seminars has roots dating back as far as the late $19^{\text {th }}$ century. Lee College in Kentucky is recognized as having offered the first freshman seminar in 1882 ("History of first university seminar", 2013). Boston University offered their own version in 1888 and Iowa State followed suit in 1900 (Schnell \& Doetkott, 2003). Taking the versions seen at these universities a step further, the first credit bearing FYS was implemented at Reed College in 1911 (Davis, 1992) and by the mid1920s there were as many as 100 freshman seminars across the nation (Schnell \& Doetkott, 2003). The freshman year seminar has not always existed in such a welcoming environment, however. Questions surrounding the academic rigor, curricular appropriateness, and overall necessity of such efforts began to circulate in the mid- $20^{\text {th }}$ century. By the 1960s there was a dramatic decline in the number of freshman seminars; to the point of near extinction. This trend did not last long, however, as the late 1970s brought the birth of the modern FYE movement (Hunter \& Murray, 2007).

The resurgence of the FYS was born from the confluence of several precipitating factors. The 1970s saw many changes in higher education. Demographic shifts brought increases in the nontraditional, first generation and minority student populations (Schnell \& Doetkott, 2003). Total undergraduate enrollment also grew at a rate of 42 percent throughout the decade bringing both more and more types of students to campus ("History of the first university program", 2013). These changes came as a surprise to 
many administrators given the decline in the college age population of the time (Dresch, 1983).

Along with these evolutions in national enrollment trends, an ideological shift occurred regarding popular views of students' development processes. Since the inception of the American model of higher education and through much of the 1960s in loco parentis had been the guiding student development model. Under this model university faculty and staff act literally in the place of parents and take the chief role in developing both the academic and moral development of students. Traditionally, colleges and universities were in control of everything in students' lives; both academic and personal. This changed in part due to the 1971 ratification of the $26^{\text {th }}$ amendment to the Constitution of the United States which changed the legal age of adulthood from 21 years to 18 years of age. In loco parentis was also largely abandoned because of changing views amongst faculty and administrators of their role in the development of students. Therefore in loco parentis was replaced during the 1970 s by an overriding belief that the lion's share of an institution's student development responsibilities began and ended at the classroom door (Bowden, 2007).

During this time unrest on campuses surrounding issues such as the civil rights movement and the Vietnam War also had an effect on the evolution of the first year seminar movement. Added layers of challenges for an increasingly diverse student body called into question institutions' role in development beyond the traditional academic sphere. One of the most galvanizing events in the resurgence of the first year seminar occurred within this context. In 1972 Thomas Jones', then president of the University of South Carolina, response to a campus riot reinvigorated the larger FYE movement. In 
addressing student concerns Jones implemented courses with specially trained instructors which were expressly designed to assist first year students. Throughout the 70s this course was continuously assessed and studied. The results showed significantly positive results on key student outcomes prompting many institutions to seek counsel from the University of South Carolina on how to find similar success in their curriculum (Hunter \& Murray, 2007).

The 1980s saw interest in first-year seminars continue to gain momentum. Dwyer (1989) identified increased numbers of students entering campus without adequate academic training, a changing curricular and regulatory environment, and a campus culture which had become less conducive to assisting first year students as major reasons for wide adoption of FYS programs. Accelerating the trend further was a 1984 report entitled Involvement in Learning: Realizing the Potential of American Higher Education released by a group from the National Institute of Education that expressly suggested college administrators reallocate institutional resources, including faculty, to increase service to first year students (Hunter, 2006). This upward trajectory of first year seminars on campuses across the nation prompted to University of South Carolina to establish the National Research Center for the Freshman-Year Experience (now named the National Resource Center for the First Year Experience and Students in Transtion) in 1986.

The 1990s continued the trend of the previous two decades and were marked by exponential growth in first year experience courses. By the middle of the 1990s the National Resource Center for the First Year and Students in Transition reported that, based upon a survey of more than 2,460 accredited colleges and universities, 71.8 percent of institutions offered a freshman seminar, with an additional 5.6 percent expressing the 
intention to add a course of this design to their curriculum at the outset of the following academic year (Schnell \& Doetkott, 2003). This trend has continued over subsequent decades and the freshman year seminar has now reached near ubiquity in American higher education. ("History of the first year seminar”, 2013).

As Barefoot (2000) describes, the two decades preceding the $21^{\text {st }}$ century saw "literally thousands of first-year programs...created with increased retention rates as the primary, if not the sole, desired outcome," (p. 14). According to the Policy Center on the First Year of College (2002), 94\% of accredited four-year colleges and universities offer a first-year seminar in which at least a portion of their students participated. Furthermore over $50 \%$ of institutions offer a first year seminar to $90 \%$ or more of their entering students (Porter \& Swing, 2006). More recently a survey conducted by the National Resource Center for the First-Year Experience \& Students in Transition (2009) reported that just over $87 \%$ of responding institutions of all types reported having a first-year seminar of some kind.

Judging by its proliferation there seems to be some level of consensus regarding the value of the first year seminar. These courses have been included in curricula since the late $19^{\text {th }}$ century and enjoy a prominent place in today's American higher education environment. Despite this level of continuity, however, there exists variability in the type of first year seminar colleges and universities offer. Though no standardized format exists, Barefoot (1992) provides a working definition:

"the freshman seminar is a course intended to enhance the academic and/or social integration of first-year students by introducing them (a) to a variety of specific topics, which vary by seminar type, (b) to 
essential skills for college success, and (c) to selected processes, the most common of which is the creation of a peer support group," (p. 49).

Padgett, Hunter and Kilgo (2011) identify some of the most common forms of freshman seminars. These include academic seminars with generally uniform content, academic seminars with various topics, professional or discipline-based seminars, basic study skills seminars, hybrid seminars and extended orientation seminars. Of these, by far the most popular is the extended orientation model of the first year seminar. The extended orientation seminar is a model in which the focus of the course is building skills necessary for the transition into the college environment. Students work on getting to know specific campuses, building social networks, and basic academic and study skills. Currently, the extended orientation model is offered at a rate of nearly $3: 1$ to the next highest model (Padgett, Hunter, Kilgo, 2011).

Extended orientation seminars are often referred to as freshman orientation courses, college survival, university 101, college transition, student success courses or a variety of other labels. These courses focus on acquainting first year students with important campus resources, developing time management skills, academic and career planning, learning strategies, and assisting common student development issues (Fidler, 1991). Over the past several decades, research on extended orientation courses for firstyear students has been ever-present in academic literature (Pascarella \& Terenzini, 1991). Students who take these courses have previously been shown to participate more often in campus activities and have higher instances of out of class faculty contact (Porter \& Swing, 2006). Research has also identified a link between course participation and higher levels of credit hour completion and academic performance and overall retention 
(Jamelske, 2008). Williford, Chapman, and Kahrig (2001) found that positive effects from taking these seminars extend all the way through to increased rates of graduation amongst course participants. Pascarella and Terenzini (2005) summarized the major research findings in this body of literature by stating that participation in these courses overwhelmingly produces "positive effects on a student's successful transition to college and the likelihood of persistence into the second year...and on a considerable array of other college experiences known to be related directly and indirectly to bachelor's degree completion," (p. 403).

Although these findings help to validate the extended orientation first year seminar's place as a crucial intervention, critiques of the manner in which these studies have been conducted have often been levied. Barefoot (2000), for example, argues that the scope of research on first-year seminars is limited and rarely extends beyond an analysis of retention rates. For example, few studies have investigated elements of these courses such as the impact of voluntary enrollment or credit bearing nature influence outcomes. Important social integration topics such as the incorporation of diversityrelated practices and curriculum have also been largely overlooked and generally the literature has explored only tangentially the relationship between first year seminars and student success outcomes (Engberg \& Mayhew, 2007). There has also been a lack of research connecting first year seminars to the intellectual development of first year students. And, perhaps most vexingly, has been the preponderance of single institution studies which lack the generalizability to provide broad answers as to the effectiveness of extended orientation first year seminars (Padgett, Keup, \& Pascarella, 2013). 


\section{Purpose of the Study}

It was in the context of the relationship between first year student success and degree attainment that I developed this study. While national graduation rates have remained stubbornly low for decades, previous work has shown that students who persist from their first to their second year of study have higher graduation rates than those who leave their institution at some point between their freshman and sophomore years. Recognizing the impact that first-to-second year retention can have on graduation rates, colleges and universities across the US have implemented a multitude of interventions aimed at first year student success. These interventions have taken many forms but the first year seminar has been the most popular model; particularly the extended orientation model of the first year seminar. As FYS's have continued to gain in popularity as a means of increasing first-to-second year retention, they have become among the most widely used and studied interventions in all of higher education. While research investigating FYS's has been prevalent, the generalizability of previous findings has been limited by the pervasiveness of single institution studies. This work has provided only limited insight as to the effectiveness of these key interventions across time and settings and has left a gap in the literature. Therefore, the purpose of this study was to generalize beyond previous findings from single institution studies and gain a broader understanding of the overall effectiveness of orientation-themed first year seminars.

To begin to address these issues, a systematic review and meta-analysis was performed. A systematic review may be defined as "an overview of primary studies which contains an explicit statement of objectives, materials, and methods and has been conducted according to explicit and reproducible methodology," (Greenhalgh, 1997, p. 
672). This type of literature review helps to limit bias and reduce the probability of chance effects which leads to more reliable results upon which to draw inferences (Higgins \& Green, 2006). The systematic review in this study was followed by metaanalysis; a form of research synthesis that uses quantitative techniques to accumulate and compare individual results of several research studies. Under this method it is studies and not individuals which act as subjects comprising the sample (Lipsey \& Wilson, 2001). As Glass, McGaw and Smith (1981) describe, "The essential character of meta-analysis is that it is the statistical analysis of the summary findings of many empirical studies," (p. 21).

A key component of the meta-analytic technique is its ability to produce a transparent, replicable summary of research findings. This is achieved in part through the systematic coding process. Systematic coding allows research synthesis, to codify individual study characteristics and, most critically, these studies' quantitative findings. Statistical adaptations are then used to identify and describe patterns within the sample's collective findings. This analysis provides information about the strength, direction, and relative importance of relationships between variables. Perhaps the greatest asset of meta-analysis lies in this ability to produce synthesized effect size estimates, combined across studies, which allow for higher powered estimates than can be provided by any single study alone (Lipsey \& Wilson, 2001). Given the context and purpose of this study, meta-analysis offers key analytic advantages via its ability to discover and describe patterns present in previous research studies.

The guiding purpose of this study was to use these techniques to synthesize previous research findings in order to gain a broader understanding of the effectiveness of 
extended orientation first year seminars. Effectiveness, however, is a broad term which can be measured in any number of ways. Therefore, for this study I measure effectiveness in terms of FYS's impact on two often measured constructs of student success: retention and grade point average (GPA). I chose to use first-to-second year retention not only because of its correlation to increased rates of graduation (ACT, 2013) but also because increased rates of student retention is the most commonly used measure of effectiveness for seminars (Barefoot, 2000). Although GPA is less directly tied to graduation than is first-to-second year retention, it has been shown to be positively correlated with retention and graduation. And although it is not a perfect measure of student success (Chartriand, 2012), I included GPA as a dependent variable in this study as it has been shown in many studies to make significant contributions to student persistence and to degree attainment (Pascarella \& Terenzini, 2005). Therefore, I used systematic review and meta-analysis in order to answer each of two guiding research questions:

Research Question 1: Does voluntary participation in an extended orientation first year seminar increase first time, full time undergraduate students' academic performance as measured by first semester or first year cumulative grade point average?

Research Question 2: Does voluntary participation in an extended orientation first year seminar increase the first-to-second year retention rates of first time, full time undergraduate students? 


\section{CHAPTER II}

\section{REVIEW OF THE LITERATURE}

Student retention is among the most studied topics in higher education (Tinto, 2007). Research concerning the departure of students from colleges and universities has been empirically investigated since the early $20^{\text {th }}$ century (Jones $\&$ Braxton, 2010). During the 1920s the earliest investigations into 'student mortality' were prompted by college registrar concerns over the failure of some students to graduate. The 1930 s saw attempts to quantify and explain attrition but until the 1950s the study of student retention progressed slowly (Boden, 2012). However, an enrollment boom and the diversification of the student body during the immediate post-World War II era changed the landscape of American postsecondary education (Thelin, 2011). This era was marked by demographic shifts, enrollment growth, and increased institutional diversity. These changes prompted a renewed interest in issues surrounding student retention and by the 1960 s influential works such as Gekoski and Schwartz’s (1961) “Student Mortality and Related Factors" Panos and Astin's (1968) “Attrition Among College Students,” and Feldman and Newcomb's (1969) The Impact of College on Students solidified the study of retention as critical to the field of higher education (Demetriou \& Schmitz-Sciborski, 2011). By the 1970s concern from administrators over student dropout (Delen, 2012) brought what Berger and Lyon (2005) dubbed the dawn of theory in the study of college student retention. 


\section{College Student Retention}

Before the study of retention began to take hold higher education during the 1960s and 1970s, student departure or attrition was viewed largely as a reflection of the individual. Those who chose not to remain were seen as less able or willing to integrate into the social and academic environment of college. In the 1970s, however, this view began to change and institutional and environmental factors were recognized as having a major role in students' decisions to stay or leave (Tinto, 2007).

\section{The 1970s}

Two formative theoretical models adapted from Durkheim's (1961) model of suicide were published during the 1970s. Spady's (1970) sociological model of student dropout in higher education became the first widely recognized model of its kind in the study of retention (Demetriou \& Schmitz-Sciborski, 2011). In this model the interaction between student characteristics and the campus environment is examined. Ultimately social integration into the campus community was thought to be the key to retaining students. The variables of academic potential, friendship support, grade performance, intellectual development, and normative congruence all contributed to social integration in the model and could be indirectly linked to student retention or attrition (Spady, 1970). In an empirical study completed one year later Spady (1971) found that, of these variables, academic performance had the strongest link to retention.

Also based on Durkeim's (1961) model, Tinto’s (1975) model of student integration draws upon the theory of suicide to "explain attrition primarily in terms of the student's failure to integrate into an institution's social and academic systems," (Wilcoxson, Cotter and Joy, 2011, p. 331). The tie from Durkheim's work on suicide is 
made via the construction of college as a "social system with its own value and social structure," (p.91 Tinto, 1975). The model assumes that the conditions which often promote suicide can also prompt dropout behavior. These conditions include insufficient interactions with others in the university community and a lack of congruency with the values and norms of the college. According to the model, the degree to which this social integration occurs plays a direct role in whether or not students remain in college. Tinto also accounts for integration into the academic systems of colleges and makes clear distinctions between "normative and structural integration in the academic domain of the college from that in the social domain of the college," (p. 92 Tinto, 1975). Based upon this understanding, Tinto's model portrays retention as a longitudinal process primarily influenced by the degree to which students fit into the structure, social and academic environment of the institution (DeWitz, Woolsey \& Walsh, 2009).

In the four decades since its publication Tinto's (1975) model has reached nearparadigmatic status in the field of retention research. This is made clear by the more than 400 citations and 170 dissertations to-date which pertain to this theory (Braxton, Milem, Sullivan, 2000; Braxton \& Hirschy, 2005; Coll \& Stewart, 2008). The model has gained immense popularity as a guiding framework for retention research and yet it has not been without its critics. Scholars have pointed to its failure to recognize the nuanced nature of drop-out behavior as the original model does not allow for the possibility of leaving as a positive action for some students. Others have criticized the limited attention that is given to integration into non-residential campuses. Further, the credence given to institutional factors that promote student withdraw has, in the eyes of some, overshadowed the impact that external factors might also contribute to dropout behavior. 
Even Tinto himself points to a lack of complexity and detail in his early work. Tinto (2007) decries the over reliance of this model and others of its time on quantitative data gathered from residential campuses with primarily majority student bodies. This, he states omitted "the experience of students in other types of institutions, two- and fouryear, and of students of different gender, race, ethnicity, income, and orientation," (Tinto, 2007, p. 3).

\section{The 1980s}

Lessons learned from these early seminal works brought about what the Study Group on the Conditions of Excellence in Higher Education (1984) called the "age of involvement." A wide range of research reinforced that student contact and involvement in the campus community work to reinforce positive student outcomes. Among the outcomes found to be related to involvement were increased rates of retention (Tinto, 2007). The most notable theories in this line of research were published by Bean (1980) and Astin (1984). Bean first produced the Model of Student Attrition in 1980 and then updated this work in 1985 while Astin's Involvement Theory followed in 1984.

Bean's (1980) Model of Student Attrition was largely based on a model of worker turnover developed by Price (1977). This was seen at the time as an alternative to traditional models of student attrition (Cabrera, Nora, \& Castenada., 1993). Bean's work contained four categories of variables thought to explain student dropout. In this causal model, Bean used dropout as the dependent variable and placed satisfaction and institutional commitment as intervening variables. The remaining categories are the organizational determinants and background variables (Bean, 1980). The Student Attrition Model posits that the intent to persist or drop out is affected by a linear process 
in which beliefs shape attitudes, and attitudes then influence behavioral intents. Bean's work supposes that beliefs may be affected by a student's experiences with organizational components of the institution itself and, in contrast to Tinto's Student Integration Model, recognizes that external factors can dramatically affect the attitudes and behaviors of college students. Bean has tested several variations on the Student Attrition Model and has largely found support for the effect that organizational, personal, and environmental variables have in shaping student attitudes and their intent to either persist or drop out (Cabrera et al., 1993). Later Bean's model was refined to include five groups of variables: background, organizational, intent to leave, environmental and outcome, and attitudinal variables (Bean, 1985).

Though gaps such as the limited the role given to environmental factors are present, Bean's Student Attrition Model has been overwhelmingly well received (Desjardins, Kim, Rzonca, 2003). Stratton, et al. (2004) describe Bean's work as a more comprehensive view of student drop-out behavior due to the explicit use of external factors in the model. Also, Bean's theory more fully incorporates the importance of behavioral intentions as predictors of persistence (Stratton, et al., 2004). In addition to this praise, Cabrera, Castaneda, Nora, and Hengstler (1992) found that, despite similarities between Tinto's Student Integration and the Student Attrition Model, the external factors highlighted in Bean's model were crucial in in explaining persistence.

Similarly, Astin's (1984) Involvement Theory stresses the role of student involvement as a means to persistence (Kiser \& Price, 2008). Astin (1984) defines involvement as "the amount of physical and psychological energy that the student devotes to the academic experience," (p. 518). In this model highly involved students are 
characterized as those who may spend a great deal of time studying, may remain on campus more often, will likely participate in organizations and interacts frequently with faculty members and other students (Astin, 1984). Astin's model of involvement mirrors Titno's (1975) concept of student integration in its assertion that the greater the student's involvement in college, the greater the amount of student learning and personal development (Astin, 1984, p. 529). Astin's theory has been the foundation for administrative practices as well as empirical studies and has been strongly supported by more recent research. For example, Crissman (2002) found that club and organization membership was positively correlated with retention while Holland, Stallings, and Braxton (2002) found that "social integration has a significant positive effect both on freshman re-enrollment intentions and institutional commitment," (p. 307).

Astin's work has helped to guide administrative practice as well as retention research through the theory that the opportunities students have to become more involved in activities on campus may determine student behaviors more so than institution type. Astin asserted that students should be afforded a great number of opportunities to interact with one another, as well as with faculty, so they might develop a stronger commitment to the institution. Statements such as this have prompted colleges and universities to craft and implement policies that increase student involvement in efforts to promote greater retention (Kiser \& Price, 2008).

In addition to theoretical work focused on student involvement the 1980s also saw the emergence of enrollment management. Hossler and Bean (1990) defined enrollment management as an "organizational concept and a set of systematic activities designed to enable educational institutions to exert more influence over their student enrollments," (p. 
5). Enrollment management is a system of marketing, recruitment, and retention whereby the whole institution is engaged in an organized effort to attract and retain students (Hossler, 1984). This approach is designed to enhance student satisfaction and subsequently to increase the number of students who remain enrolled until they graduate. The crux of this approach is that if programs and services offered by institutions are coordinated, interconnected, and intentional, then an institution can be more responsive to students' needs. Using this model, institutions address their needs for stable enrollment and tuition as well as students' needs for a quality education (Smith, 2000). The practice of enrollment management was originally developed as a reaction to declining enrollments of the late 1970s but due to its widespread adoption on campuses across the United States it is now considered the hallmark of retention work during the 1980s (Berger \& Lyon, 2005).

\section{The 1990s}

Retention research during the 1990s shifted from a focus on enrollment management and theories of involvement and began to focus on the retention of students from underrepresented populations and/or disadvantaged backgrounds (Demetriou \& Shcmitz-Sciborski, 2011). The 90s saw focus in scholarly literature on issues such as access, choice, affordability, and persistence of students from varied backgrounds.

Scholars began to position diversity and multiculturalism as tools which could be used to promote greater retention (Swail, 2004). Work by Tinto (1993) continued during this decade and highlighted groups such as African American students, those from lowincome backgrounds, adult students, and transfer students as bringing unique experiences and needs to campus. During the second half of the decade focus shifted toward student 
transitions and particularly toward first-year transitions (Demetriou \& Schmitz-Sciborski, 2011). For example, Swail's (1995) framework for retention highlights the need for coordination amongst academic and student services, while Wyckoff (1998) suggested that the interactions a student has with members of the campus community influence retention, and Anderson and McGuire (1997) highlighted academic advising services as an imperative tool to keeping larger proportions of students enrolled.

Much of the work studying retention during the 1990s was based on theoretical models by scholars such as Bean (1980), Pascarella (1980), and Tinto (1975). Much of the work from this period focused on the impact of variables such as academic performance, academically related experiences (including first year seminars), financial aid, student-faculty interaction, peer interactions, choice of major, and integration into the campus community (Pascarella \& Terenzini, 2005). Among the major findings related to these variables included Adelman's (1999) conclusion that first-year grades and subsequent trends in academic performance are strong positive predictors of graduation. Similarly Cabrera, Nora and Castenada (1993), among others, found that academic achievement in the first year of college is a particularly powerful predictor of future retention and degree attainment. In terms of the impact of financial aid on retention results are more mixed. Cuccaro-Alamin (1997), for example, found that students who did not receive aid graduated at about the same rate as those who did whereas St. John and Masten (1990) estimated that financial aid increased the odds of baccalaureate attainment by about 11 percent.

Research in the 1990s also saw a focus on the interaction of students with faculty and with other students. Decades of investigation has shown that contact with faculty 
outside of the classroom promote positive student outcomes including increased rates of persistence (Pascarella \& Terenzini, 2005). Astin (1993), for example, stated that, even while controlling for a multitude of variables, student-faculty interaction has significant positive correlations with every attainment outcome. Peer-to-peer interaction has been shown to have a similarly powerful impact on student persistence. Astin (1993) went so far as to describe a student's peer group as the most influential factor affecting a student's growth while in college. Other studies during the 1990s pointed to peer-to-peer interaction and support as positively impacting students' intent to persist (Eimers \& Pike, 1997) as well as actual persistence into the second year (Bank, Slavings, Biddle, 1990). Work by Chang (1999) found interactions with diverse groups of peers as having a positive impact on persistence and degree completion.

Finally, much work in the 90s focused on the impact of the choice of major and academic and social engagement on student retention. Many studies have found that, all else being equal, students majoring in science, engineering, mathematics, or business are more likely to persist and graduate than their peers in other majors (Adelman, 1998; DesJardins, Kim \& Rzonca, 2002). Others (Seymour \& Hewitt, 1997) pointed toward classroom climate and the culture of disciplines as factors that make the choice of major impactful in student retention. In addition to the impact of students' choice of major, integration into the college environment has been shown to influence retention behavior as well. Pascarella and Terenzini (2005) summarize research findings from the 1990s surrounding integration by stating that the level of student involvement and integration in any of the components of an institution's academic and social systems can be a critical factor in students' persistence decisions," (p. 426). 


\section{The 21st Century}

The wide lens used to view retention during the 1990s carried over into the early 2000s. From this perspective a multitude of individual, social, and organizational factors are thought to impact student retention and attrition (Demetriou \& Schmitz-Sciborski, 2011). Tinto (2007) depicts research during this area as bringing a broader understanding of the many factors that might influence student behavior. Retention research in the $21^{\text {st }}$ is marked by a deeper appreciation for the experiences of students of different backgrounds and for the impact of broader cultural, economic, and social forces. There is also greater attention paid to the importance of differences in institutional settings.

Finally, modern models of student retention move past the limits of early theories in their recognition of the complexities of student retention (Tinto, 2007). The overriding theme of this modern era of research is that a holistic approach must be taken to understanding student departure and promoting higher levels of retention. The interactions that students have all across campuses matter and in order to make those interactions beneficial institutions must offer accessible academic and social support services in order to assist the changing student body in persisting through to degree attainment (Tinto, 2007; Demetriou \& Schmitz-Sciborski, 2011).

Given the depth and breadth of retention research in postsecondary education it is nearly impossible to detail each variable which has been shown to impact retention. In nearly a half-century of literature variables such as academic preparation, academic engagement, social engagement, financial concerns, and demographic characteristics have all been shown to impact student retention (Demetriou \& Schmitz-Sciborski, 2011). In their review of retention research Peleltier, Laden, and Matranga (1999) focus on 
studies which have found student involvement, ethnicity, gender, age, residency status, and membership in campus organizations such as Greek life to be directly related to persistence. The variables only scratch the surface of what has been linked to retention. However, Swail (2004) states that the entire spectrum of retention research can categorized into cognitive, social, and institutional factors. Cognitive factors such as math, writing, and reading proficiency Swail states comprise a students' academic ability. Social factors include interaction with peers, personal attitudes and personal history. Finally, institutional factors include teaching ability, financial aid, academic and student support services, and curricular rigor. According to Swail (2004) the vast majority of factors which impact student persistence can be placed into one of these buckets. These broad categories help to organize the vast field of retention research but do they do little in answering what is most important in the fight to retain and graduate college students.

\section{First Year Retention}

If there is agreement amongst scholars surrounding the challenge of retention then there also exists a near consensus that the most important part of the journey toward retention and eventual degree attainment is the first year (Stratton, et al., 2008). Nationally in 1999 and 2000, 25.8\% of first year students did not return to their institution for their second year of study (ACT, 2001). Nearly a decade prior, Tinto (1993) found that $28 \%$ of students entering four year institutions left after their first year. Further, over a third of all 1992 high school graduates who earned a bachelor's degree by 2000 earned the degree at an institution other than that at which the student began his or her academic career (Herzog, 2005). Despite many best efforts retention rates amongst first-year students have stayed relatively consistent. Boden's (2012) longitudinal study of 
118 years of continuous registration records at one public university highlights this by showing almost no change in persistence from first to second year with rates as they consistently hovered between $60 \%$ and $70 \%$.

For first time college students, the first year is a unique and often difficult experience. This period in an individual's academic career is a time of transition and adjustment to the social and academic demands of college (Crissman, 2002). The firstyear transition has been found to be greatly influenced by factors that student bring to campus with them. Individual personality traits, academic self-concept and intrinsic motivation are all likely to affect a student's integration into the college environment (Andrade, 2008). However, it is often the academic experience of a student that most heavily influences the decision to persist. Many students enter postsecondary institutions lacking the necessary skills, experiences, and training to successfully integrate (Schrader $\&$ Brown, 2008). The disparity that often exists between the high school academic experience and college expectations often causes.

Those students who enter higher education with poor academic preparation and with poor prior performance may be more at risk for academic failure or early withdrawal from their original institution of attendance (Terrion \& Daoust, 2012). Individuals often find that their college courses and instructors are much different from what they experiences while in high school. The National Research Council (2002) cites college instructors' expectations that students be able to "draw inferences, interpret results, analyze conflicting source documents, support arguments with evidence, solve complex problems that have no obvious answer, draw conclusions, offer explanations, conduct research, and generally think deeply about what they are being taught." According the 
2006 National Survey of Student Engagement the majority of first year students are also asked to work on complex projects, with groups both in an out of the class, and to make presentations about what they have learned. Writing requirements are more detailed, longer, and more complicated as compared to high school and there is an expectation of independent learning and self-reliance. The collegiate academic atmosphere is contrasted with the traditional high school setting in which students are most often given prescribed tasks to complete, asking little of their cognitive reasoning ability. Students are also often socialized to look for the "right" explanation while in high school as opposed to analyzing texts and allowing for contextual caveats as they are often asked to do at the postsecondary level (Conley, 2007). Therefore, when confronted with an academic environment in which greater rigor is coupled with more ambiguity many new college students struggle to excel academically in their first year; a propellant of student departure behavior.

In addition to the social and academic integration issues that confront many first year students, organizational and cultural issues within the institution can also have a great effect on student persistence. Pascarella and Terenzini (2005) posit that students' experiences once they arrive on campus have a greater impact on persistence than background characteristics or personal commitment to graduation. Concerns over the quality and structure of undergraduate education have been raised loudly in recent decades. Critics decry the use of "large lecture classes, incoherent curriculum, inconsistent quality of advising, and instruction by graduate teaching assistants and part time instructors... as well as large, impersonal, bureaucratic, and fragmented," organizational structures (Talburt \& Boyles, 2005). These structures have made it more 
difficult for many traditional first year students to integrate into their new community. The traditional model of close and sustained contact with faculty that reinforced classroom learning is now absent from many campuses. Adapting and integrating into these large, bureaucratic organizations can be extraordinarily difficult; especially for students who do not hold a great deal of formal power or authority in the organization (Godwin \& Markhim, 1996).

Difficulties posed by institutions themselves can have dire consequences as the act of social integration into the campus, as identified by Tinto (1975), is often viewed as one of the most key ingredients in promoting student retention. Students' ability to acculturate to the nuances of new peer groups, new academic pressures and unique organizational characteristics have a great effect on the likelihood that they will remain enrolled in their college or university. When all forms of integration, especially academic and social integration, are occurring in conjunction with one another, the impact on college student retention is at its greatest (Terrion \& Daoust, 2012).

\section{Changing Demographics}

Confounding the difficulties traditionally faced by first year students has been a massive shift in the type of student that is entering the postsecondary system. Historically, higher education was comprised mostly of white, academically skilled, middle or upper-class students (Thelin, 2011). This population has evolved into a more complicated mix in terms of academic preparation, age, socioeconomic background and goals for enrolling in college (Gordon \& Grites, 1984). The academic, social, psychosocial and cultural concerns that plague the first year student (Pascarella \& Terenzini, 2005) are now being complicated further by the unique difficulties faced by 
the new college student body. The population of non-traditional and underrepresented students brings to campus a shift in demographics as well as a revised set of needs. Often these students do not possess accurate notions of what constitutes undergraduate education, where they wish this education to take them, and what will be expected of them by institutions. Greater difficulty in fully understanding and connecting to academic and social cultural norms might also exist in the diversifying student population (Colton, Connor, Shultz, Easter, 1999). While these struggles are not unique to nontraditional students the severity of their impact is.

Moldonado, Rhoads and Buenavista (2005) point out that, while non-white students are attending postsecondary education institutions at record levels, they also continue to persist at a lower rate than their white counterparts. Despite the increase of students from historically underrepresented populations, a large disparity in the already troubling overall graduation rates exists. Degree attainment ratios for minority students are between 1:2 and 1:3 compared with white and Asian students (Swail, Redd, \& Perna, 2003). There is undoubtedly no single answer to retention difficulties; particularly for largely at-risk populations such as minorities. There are, however, very clear gains to be made through increased retention of at-risk student populations. Improvements in persistence and graduation impact campus diversity and increase career future economic opportunity amongst traditionally marginalized populations (Heaney \& Fisher, 2011). The allure of this win-win proposition has spurred a steady tide of research and programmatic efforts to explore ways in which minority students can begin to persist at greater rates. 
The benefits to be gained from higher retention rates are not limited, however, to one student population. Issues concerning attrition rates and the changing face of the American university have prompted institutions and scholars to research student retention and departure extensively (Pascarella \& Terenzini, 2005). Studies investigating student sub-populations, academic careers paths, institutional settings, and a plethora of other variables thought to be related to student persistence and the first year continue to be conducted. This literature has bolstered previous work that points to first-to-second year retention as critical in working toward degree attainment. Regardless of student type or population the odds of degree attainment dramatically increase for those who traverse the first year (Wells, 2009; Crissman, 2002).

\section{First Year Seminars}

The most prevalent tool used in modern higher education to promote first-tosecond year retention has been the first year seminar (Padgett, Hunter, Kilgo, 2011). The two decades preceding the $21^{\text {st }}$ century saw "literally thousands of first-year programs...created with increased retention rates as the primary, if not the sole, desired outcome," (Barefoot, 2000, p. 14). During this time period the first year seminar has continued to be the most popular of these programs. In 2002 The National Policy Center on the First-Year of College reported that of all responding accredited colleges and universities $94 \%$ offered a first-year seminar to at least some students and more than $50 \%$ offer a seminar to $90 \%$ or more of their first year students (Policy Center on the FirstYear of College, 2002). More recently, the 2009 Survey of First Year Seminars (Tobolowsky \& Associates, 2008) shows that $87.3 \%$ of responding institutions offer a first year seminar of some kind. The near omnipresence of these seminars on today's 
college and university campuses has garnered a great deal of attention from audiences of all types. Topics surrounding first year seminars and their effect on myriad outcomes have become rampant in scholarly literature (Pascarella \& Terenzini, 1991; Barefoot, 2000). There has also been a recognition of the importance of first year issues via the development of various philanthropic efforts such as the Foundations of Excellence project, policy initiatives such as the creation of the Policy Center on the First Year of College, and research driven efforts such as Indiana University's National Survey of Student Engagement and the Your First College Year survey at UCLA's Higher Education Research Institute (Hunter \& Murray, 2007). Given its storied past and modern prevalence it is little wonder that the first-year seminar is amongst the most researched courses in the undergraduate curriculum and widely considered an invaluable instructional tool for achievement of institutional goals including student development, retention and graduation (Padgett, Keup \& Pascarella, 2013).

\section{Seminar Typology}

Based upon the prolific nature of the intervention there is some level of agreement regarding the value of the first year seminar. These courses have been included in curricula since the late $19^{\text {th }}$ century and enjoy a prominent, if not nearly ubiquitous, place in today's American higher educational environment. Despite this level of continuity, however, there is variability in seminar typology. Hunter and Linder (2005), for example, state that first year seminars "assist students in their academic and social development and in their transition to college," (p. ). A seminar, by definition, is a small discussionbased course in which students and their instructors exchange ideas and information. In most cases, there is a strong emphasis on creating community in the classroom," (pp. 
275-276). Barefoot (1992) offers greater specificity by describing the freshman seminar as "a course intended to enhance the academic and/or social integration of first-year students by introducing them (a) to a variety of specific topics, which vary by seminar type, (b) to essential skills for college success, and (c) to selected processes, the most common of which is the creation of a peer support group," (p. 49). Barefoot (2004) also posits a general definition that can be used across campuses by allowing for the reality that the particulars of each seminar will vary but that the "common goal is to increase both social and academic integration of first-year students and thereby improve rates of student retention," (p. 14). Though the definitions provided by these scholars vary, they provide some degree of uniformity to the construct of the first year seminar. What is clear from these definitions is that first year seminars, regardless of what differences may exist between individual courses or campuses, are designed to promote academic and social integration of first year students into the campus in order to meet the institutional goal of increased retention rates.

There does exist within higher education a certain degree of uniformity in the goals of first year seminars. The delivery models, curricular designs, and structures of these seminars, however, can vary greatly across institutions. Seminars may vary in several meaningful ways particularly with regard to content and course structure. Examples of seminar designs include courses with only academic content, those with a focus on student life and success strategies, or a blend of academic content and student success topics. The degree to which interdepartmental collaboration for delivery of the courses exists between academic and student life units varies greatly as well. Finally, the 
topics and activities and the degree to which, if at all, freshman seminar curriculum is paired with other courses can differ between institutions (Hendel, 2007).

Padgett, Hunter and Kilgo (2011) identify some of the most common forms of freshman seminars. These include academic seminars with generally uniform content, academic seminars with various topics, professional or discipline-based seminars, basic study skills seminars, hybrid seminars and extended orientation seminars. Though varying in curricular structure, Murphy (1989) posits that there exits four common assumptions across seminar types:

“1) students need to identify with both the college and a peer group; 2) the seminar creates bonding; 3) there are certain skills and knowledge associated with success in college that can be identified and taught; and 4) faculty training is necessary for those involved with the course," (p. 379).

Despite the variability between course designs and implementation methods, first year seminars are overwhelmingly consistent in their purpose of assisting students' transition into the university environment while subsequently raising retention rates for the institution. There also exists at least some degree of regularity in the delivery model of freshman seminars across institution types. The extended orientation model is by far the most popular iteration of these courses. In this version of the FYS the students foci are often building skills necessary for the transition into the college environment, getting to know campus, building social networks, and basic academic and study skills building. Currently, the extended orientation model FYS is offered at a rate of nearly $3: 1$ to the next highest model (Padgett, Hunter, Kilgo, 2013). 


\section{Extended Orientation Seminars}

Extended orientation seminars tend to be courses that focus on student transition and success. These seminars are often referred to as freshman orientation courses, college survival courses, university 101, college transition, student success courses or a variety of other labels. The goal and content, however, remain largely the same. These seminars most often focus on acquainting first year students with important campus resources, developing skills such as time management, planning for academics and the career, learning strategies, and assisting in the understanding and navigation of common student development issues (“History of First Year Seminars”, 2013). Courses of this design are implemented as a part of institutional efforts to ease first year transitions in hopes that this will increase first to second year retention rates and subsequently persistence to graduation. Given the larger national emphasis on retention goals and the prevalence of first year seminars, particularly the transition-themed model of first year seminar, it is little wonder that the past several decades have seen a large and diverse body of research develop surrounding the effectiveness of one of postsecondary education's most often employed interventions: the extended orientation first year seminar (Williford, Chapman, Kahrig, 2001).

Over the past several decades, research on extended orientation courses for firstyear students has been ever-present in academic literature. While the majority of this research has focused on investigating the impact these courses have on retention and academic performance measures (Padgett, Keup \& Pascarella, 2013), many other variables thought to be associated with integration and student success have also been explored in relation to participation in an extended orientation first year seminar (Hendel, 
2007). Williford et al. (2001) found that positive effects from taking these seminars extend all the way through to increased rates of graduation amongst course participants. Seminars may also impact key constructs outside of measures such as retention and graduation rates. Participants have previously been shown to participate more often in campus activities and have higher instances of out of class faculty contact (Porter \& Swing, 2006). Still other studies have found that seminar participation is tied to increases in overall satisfaction with the first year experience and engagement with the campus community (Hendel, 2007). The overwhelming trend of this research shows positive results from course participation; particularly in regards to measures of retention and academic achievement (Padgett, Keup, Pascarella, 2013). 


\section{CHAPTER III \\ METHODOLOGY}

The current study was designed to fill a gap in the literature investigating the effectiveness of extended orientation first year seminars (FYS). Specifically, metaanalytic procedures were employed in order to quantitatively synthesize existing research examining the effectiveness of these courses in promoting academic achievement and progress toward degree attainment as measured by freshman year grade point average (GPA) and first-to-second year retention rates respectively.

\section{Paradigmatic Framework}

I approached this study from a utilitarian perspective wishing to measure the overall effectiveness of extended orientation first year seminars on key student success outcomes and did so using post-positivist assumptions. As opposed to positivism wherein absolute truth is sought, this framework assumes that research is imperfect and absolute truth cannot be found. From a postpositivist perspective, there cannot be certainty about the cause and effect relationship between variables and human behavior. However, postpositivism assumes that numeric measures of these relationships can be used to determine the most likely causes of certain effects or behaviors (Creswell, 2009). Therefore, this study does not seek to answer the question of whether participation in first year seminars causes first year student success. Instead, through a postpositivist lens, I attempted to assess whether FYS participation is related to specific measures of first year student success such as GPA and retention. 
This paradigmatic stance also informed the choice of dependent variables in this study. In posing higher cumulative GPAs and first-to-second year retention rates as desirable outcomes for all students, I am in danger of posing the alternatives as wholly negative. This positionality ignores the nuances of the student experience; particularly with regard to the retention outcome. When measured as a binary variable, retention almost inherently positions the retention of students as a desirable outcome and the alternative, student departure, as negative. This view tends to characterize those students who do not return for their second year as dropouts or departures but fails to account for modes of student mobility which may be beneficial to the individual. Students may engage in upward transfer, for example, wherein he or she leaves for a more desirable institution or they may transfer laterally to a similar school that they feel is more appropriate. They may also "stop-out" with an intention and plan to return to their home institution or they may engage in a reverse transfer wherein they move to a lower division, usually 2-year, institution (Adelman, 2006). In each of these scenarios, and in the plethora of other ways that students move into and out of institutions, students may be acting in a manner that is beneficial to his or her academic future. Yet, when measuring the success of first year students by the rate of return to the second year, much of this is missed. I acknowledge this limitation to the use of first-to-second year retention rates as a proxy for the effectiveness of first year seminars. However, in approaching this study from a utilitarian, post-positivist perspective I have used this dependent variable in a manner similar to the manner in which college and university administrators might. It is through this lens that I will interpret the results of this study and eventually address the 
guiding question of whether participation in an extended orientation first year seminar is effective in promoting key student success outcomes.

\section{Study Inclusion Criteria}

Studies were required to meet several criteria to be included in the meta-analysis. First, studies must have examined a first year seminar with an extended orientation/transition themed curriculum. That is, seminars must have been designed with curricular features such as academic writing exercises, public speaking requirements, group work assignments, and other tools used to assist in the transition from high school to college level coursework and expectations. Co-curricular components such as involvement by student affairs professionals, service learning activities, or librarian-guided research practice may also have been present, but were not required. Second, studies must have compared students who were enrolled in an extended orientation FYS to students who did not receive this experience. Third, the research design must have been quantitative in nature. Fourth, studies must have measured students' cumulative freshman year GPA and/or first-to-second year retention rates. Fifth, studies must have taken place at a 4-year college or university in the United States. Finally, student enrollment in the seminars must have been voluntary.

I chose to include only voluntary enrollment seminars because these courses are open to the entire first year population and are not specifically designed for a specific subset of students. First year seminars which are mandatory for academically at-risk students or for students who are in certain majors, for example were not included in this sample. By focusing on seminars with voluntary enrollment open to the entire first year population, I allowed for the possibility of students of all types to be included in this 
study. Had I included only studies which examined courses designed for at-risk students, for example, then the generalizability of the results of this meta-analysis would be limited only to that sub-population of first year students. As the purpose of this study was to gain a broader understanding of the effectiveness of first year seminars in general, the voluntary enrollment criterion was needed in order to synthesize studies which included a variety of first year students. Finally, I did not include studies in which enrollment in seminars was mandatory for all students in an institution as the lack of an internal (or "local") comparison group would not have allowed for the calculation of a raw mean difference effect size or odds ratio. Therefore, while the nature of voluntary student enrollment can be a complicating factor, only those studies which examined voluntary enrollment first year seminars were included in the sample.

\section{Literature Search Strategy}

Several strategies were employed to obtain studies that met the inclusion criteria. First, electronic reference databases were searched in order to find as much pertinent literature as possible. The databases used were: EBSCO Academic Search Premier, Education Full Text H.W. Wilson, Educational Resources Information Clearinghouse (ERIC) EBSCO version, ProQuest Research Library, PsycINFO, Dissertation Abstracts International, Social Sciences Abstracts, and Web of Knowledge/Web of Science. These eight databases were searched using four categories of keywords (shown in Table 1). 


\begin{tabular}{llll}
\hline $\begin{array}{l}\text { Table 1 } \\
\text { Keyword Searches }\end{array}$ & & & \\
\hline First year seminar & $\begin{array}{l}\text { Academic } \\
\text { Performance }\end{array}$ & Retention & $\begin{array}{l}\text { Study } \\
\text { design }\end{array}$ \\
\hline First year experience & GPA & Persist & Empirical \\
First year seminar & Academic & First-to-second & Effect \\
Freshman seminar & Achiev* & Freshman-to-sophomore & Study \\
First year & Academic achiev* & Retention & Control \\
University seminar & Grades & Retain* & Compar* \\
University 101 & Perform* & Transfer & Findings \\
Orientation seminar & & dropout & \\
Transition-themed & & & \\
seminar & & & \\
\hline
\end{tabular}

Note. All terms are connected by OR within columns, and AND across columns.

Note. Terms with * attached were truncated so all forms of term were searched for.

Keywords were developed based on the pre-determined inclusion criteria detailed above. Keywords in the first category, "First Year Seminar", were intended to gather studies which investigated FYS programs. The "Study Design" category included terms used to obtain studies which reported quantitative results. Finally, the categories of "Academic Performance" and "Retention" used keywords intended to locate studies that measured students' GPA and/or persistence from term-to-term or year-to-year. Keywords were entered into search fields surrounded by quotations and in each database the most inclusive limiter was used to allow for the greatest possible number of pertinent studies to be returned. 
Beyond the electronic databases search, the primary avenue through which studies were searched for was The National Resource Center for the First Year Experience and Students in Transition (NRC) at the University of South Carolina. The NRC offers resources for investigation of issues surrounding students' transition into college and university life including published research and conference presentations. The NRC was contacted directly with a request for any research pertinent to this study which may not have been available on their website or in publication or previous conference proceedings. The NRC also hosts an online list serve: the Freshman Year Experience (FYE) listserv. An announcement was made on this forum detailing the work of this study and requesting any unpublished or ongoing work known to the scholars and practitioners who are members of the listserv. The protocol used to request studies is included in Appendix C.

Finally, a hand search was conducted in selected journals and conference proceedings. The Journal of Higher Education, Journal of Student Affairs, Journal of College Student Retention, and the Journal of the First Year Experience and Students in Transition were individually searched for applicable studies published in the past ten years. Conference proceedings from American Educational Researchers Association (AERA), Association for the Study of Higher Education (ASHE), and the National Conference on Students in Transition were also screened for pertinent research conducted in the last ten years.

After completing the electronic database search and the subsequent searches for 'grey literature', all gathered studies were uploaded into citation management software. 
Using this software a search for duplicate studies was performed and studies obtained more than once were removed from the initial sample.

\section{Coding Strategy}

Following the execution of the literature search strategy, the initial pool of gathered studies was coded in two phases. In the first phase, titles and abstracts of studies were coded using the screening coding guide in Appendix A. This initial screening was used to determine whether or not studies were likely to meet the established inclusion criteria. Studies which were coded with a 'Yes' or 'Can't tell' for all items on the screening coding guide were obtained for further investigation. The full text of these articles was then coded using the screening guide in Appendix A. Studies which were coded with a 'Yes' for each of the six items were included in the metaanalytic sample. For items coded with 'Can't tell' an attempt was made to contact the study's author for clarification. If, at any point, a study was coded with a 'no' for any of the six items on the screening coding guide it was eliminated from the sample.

In the second phase, the full coding guide (available in Appendix B) was used to identify and organize study details. When available, information was coded regarding settings, study contexts, authors, publication information, research methods, intervention and sample characteristics, outcomes measured, findings, and other substantive details. Study characteristics which required relatively high degrees of inference relied upon preestablished definitions. Included studies were also coded by a second doctoral candidate. This second coder was trained in quantitative research methods and is familiar with the postsecondary context in which these studies occur. Further, the second coder was trained in systematic review methods for this study. Regular meetings were held between 
coders to discuss difficult coding decisions. These meetings were also used to develop a normative understanding of the coding protocol and to address discrepancies in coding decisions (Wilson, 2009). To assess reliability each code was compared for agreement between me and the second coder. Disagreements were discussed thoroughly and in cases in which an agreement could not be reached I made the final coding decision.

Coding for these pertinent details was of great importance in this study for two primary reasons. First, the volunteer nature of FYS participants introduced the potential for volunteer bias to threaten both the external and internal validity of results. Because participants in these studies were not randomly assigned to either the condition (FYS) or control groups (non-FYS) groups it was critical to measure the baseline comparability of groups in order to assess whether pre-existing differences between non-FYS and FYS students could have affected results. Therefore, coding for details such as High School GPA and ACT scores would allow for a greater understanding of differences between groups prior to the intervention. Secondly, because studies included for meta-analysis were of varying quality, it was critical to code for methodological details. Coding for details such as sample size and the use of matching or statistical control allowed me to test for the impact that these important differences in study might have had on outcomes. In coding for these methodological and FYS or student-related study details I attempted to allow for tests which would account for both baseline group differences due to volunteerism as well as varying degrees of quality in primary studies.

\section{Publication Bias}

In part because published studies are easier to find, the preponderance of studies obtained for a meta-analysis will likely be found in academic journals (Borenstein, 
Hedges, Higgins, \& Rothstein, 2009). However, studies published in academic literature are often not fully representative of the findings of all studies investigating a particular topic. Studies with statistically significant results are more likely to be published than those with non-significant results (Sutton, 2009). Dickersin \& Min (1992), for example, found that studies with non-statistically significant results are $60-80 \%$ less likely to be published. This can have an impact on the results of a meta-analysis due largely to the relationship between effect size and statistical significance. As the effect size increases, regardless of sample size, the likelihood of a statistically significant result increases as well. Therefore, in a population of studies which examine the magnitude of a particular relationship, the studies with larger effects are more likely to be statistically significant and therefore to be published (Borenstein, et al., 2009). This means that limiting the sample for a meta-analysis to only published results is likely to lead to an overestimate of effects. This is known as publication bias and can be a threat to the validity of metaanalyses. This threat was addressed in this study primarily through systematic review techniques designed to obtain unpublished or 'grey' literature. In addition to these techniques, however, both trim and fill and funnel plot analyses were used to test for the possible influence of publication bias.

First, a funnel plot was used to determine whether there was any evidence of bias in the sample of obtained studies. A funnel plot analysis acts as a visual representation of the relationship between study size and effect size. Studies are plotted with effect sizes on the $\mathrm{X}$ axis and their standard errors on the $\mathrm{Y}$ axis. Standard error values run from the smallest on the top of the $\mathrm{Y}$ axis to the largest on the bottom. As such, smaller studies appear at the bottom of the graph. These will tend to exhibit greater sampling error 
variation due to their lower level of precision. If there is no bias present the studies should be scattered symmetrically about the mean effect size, suggesting that the individual study effects vary due only to random sampling error. If bias is present the larger studies at the top of the funnel should remain distributed symmetrically around the mean while smaller studies will be asymmetrically scattered toward the bottom (Borenstein, et al., 2009). The symmetry of the plot in Figure 1 was used to indicate whether there was a possible presence of bias.

Duval and Tweedie's (2000) trim and fill analysis is a formalization of the qualitative approach used in the funnel plot. Trim and fill is an iterative process employed when the possible presence of publication bias is detected. If asymmetry is detected in the funnel plot the trim and fill technique is used to estimate the number of studies which lie in the asymmetric portion and then to trim off this outlying part of the plot (Duval \& Twedie, 2000). This procedure begins by 'trimming' the most extreme small study from the positive side of the funnel plot. Once this study is removed a new mean effect size is computed and the funnel plot is analyzed for symmetry using this new metric. This process is repeated until the plot shows no asymmetry. This trimming technique produces an adjusted effect size but it also reduces the variance of effects and produces too narrow a confidence interval. To adjust for this reduction in variance the original 'trimmed' studies are added back into the plot along with a mirror image for each and this new data set is used to calculate the variance of the pooled estimate (Borenstein, et al., 2009; Sutton, 2009). This trim and fill technique provides an estimate of the unbiased effect size. 


\section{Effect Size Metric}

Once relevant studies were gathered and coded for inclusion and pertinent details, a choice was made regarding which effect size metric would be used in the meta-analysis. The choice of metric depends largely upon "the nature of the research findings, the statistical forms in which they are reported, and the hypotheses being tested by the metaanalysis," (Lipsey \& Wilson, 2001, p. 34). For this study these considerations led to the choice of different effect size metrics for each of the two dependent variables of interest. For the variable of GPA the unstandardized mean difference effect size (raw mean difference) was calculated and for measures of retention the logged odds ratio was used.

The raw mean difference effect size was selected for GPA as grade point average is a widely interpretable scale and all studies in the sample that measured academic achievement used GPA to do so. When the same measurement and scale are used across studies the effect size metric can be constructed simply from the difference between group means (Lipsey \& Wilson, 2001). The raw mean difference, $D$, for independent groups was calculated simply by differencing the two group means on GPA as detailed in Formula 3.1:

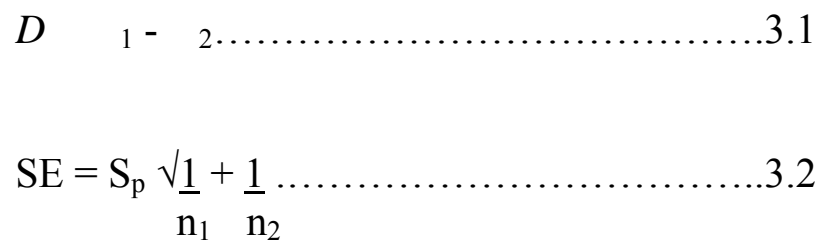

where ${ }_{1}$ is the mean for Group 1, ${ }_{2}$ is the mean for Group 2, $\mathrm{n}_{1}$ is the number of subjects in Group 1, $\mathrm{n}_{2}$ is the number of subjects in Group 2, and $\mathrm{S}_{\mathrm{p}}$ is the pooled standard deviation. The Standard Error (SE) is calculated for use in weighting effect sizes (see "Meta Analytic Procedures", below). When assuming equal population 
standard deviations between groups, as is the norm in most parametric data analysis (Borenstein, et al., 2009), the pooled standard deviation is calculated as shown in formula 3.3 .

$$
\mathrm{S}_{\mathrm{p}}=\frac{\sqrt{\left(\mathrm{n}_{1}-1\right) \mathrm{S}_{1}^{2}}}{\left(\mathrm{n}_{1}-1\right)+\left(\mathrm{n}_{2}-1\right) \mathrm{S}^{2}}{ }_{1} \ldots \ldots \ldots \ldots \ldots \ldots .3
$$

where $\mathrm{S}_{1}$ is the standard deviation for Group 1 and $\mathrm{S}_{2}$ is the standard deviation for Group 2.

For studies in the sample that reported retention as a dependent variable the odds ratio was used as the effect size statistic. The odds ratio is an effect size statistic that compares two groups in terms of the relative odds of an event. In this case groups were compared in terms of the relative odds of members being retained versus not retained at their current university. Frequencies or proportions of selected outcomes can be used to calculate odds ratios (Lipsey \& Wilson, 2001). Therefore studies in this sample that reported either the number of FYS students retained versus non-FYS students retained or the proportion of students retained in the FYS versus non-FYS categories can be used to calculate this effect size. The odds ratio for frequencies is calculated as shown in formula 3.4 .

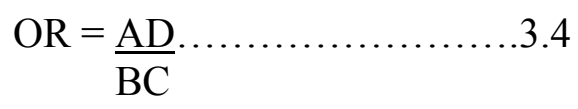

where A is FYS members who were retained, D is Non-FYS members who were not retained, B is FYS members who were not retained, and C is Non-FYS members who were retained.

The odds ratio for proportions is calculated as shown in formula 3.5.

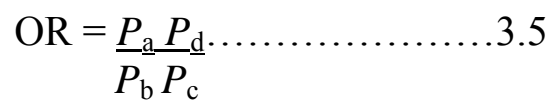


where the $P_{\mathrm{a}}$ is the proportion of FYS members who were retained, $P_{\mathrm{d}}$ is the proportion of Non-FYS members who were not retained, $P_{\mathrm{b}}$ is the proportion of FYS members who were not retained, and $P_{\mathrm{c}}$ is Non-FYS members who were retained.

The odds-ratio has the "inconvenient form of being centered around one rather than zero," (Lipsey \& Wilson, 2001, p. 53). When left in their original form, odds ratio values between 0 and 1 indicate a negative relationship, values between 1 and infinity a positive relationship, and an odds-ratio of 1 indicates no relationship. This is not a symmetric number scale. For example, an odds ratio of 0.5 indicates the same strength of relationship, but in the opposite direction, as an odds-ratio of 2. Assuming equal weights, these odds ratios should average to no effect (i.e., 1.0) but instead average to an odds ratio of 1.25 . In order to add symmetry to this scale a conversion to the natural log of the odds-ratio is performed (Fleis \& Berlin, 2009; Borenstein, et al., 2009; Lipsey \& Wilson, 2001). The logged-odds ratio has a mean of 0 , a standard deviation of 1.83 and is approximately normal in its distributional form. Therefore, negative values indicate negative relationships, positive values reflect positive relationships, and a logged oddsratio of 0 indicates no relationship (Lipsey \& Wilson, 2001). Using the earlier example, the $\log$ of an odds ratio of 0.5 would be -0.69 while the $\log$ of an odds ratio of 2 would be +0.69 . The average of these two effects is equal to 0 which correctly implies no mean intervention effect (Deeks, Higgins, \& Altman, 2008). In addition to maintaining symmetry in the analysis, converting the odds ratio to its logged odds version makes the standard error easier to calculate (Lipsey \& Wilson, 2001). 
The log odds transformation is detailed in formula 3.6 and the standard error of the log odds ratio in formula 3.7.

$$
\begin{aligned}
& \log _{\mathrm{OR}} \ln (\mathrm{OR}) \ldots \ldots \ldots \ldots \ldots \ldots . . . . . . .6 \\
& \mathrm{~S}_{\mathrm{LogOR}}^{2}=\frac{1}{\mathrm{~A}}+\frac{1}{\mathrm{~B}}+\frac{1}{\mathrm{C}}+\frac{1}{\mathrm{D}} \\
& \mathrm{SE}_{\mathrm{LogOR}}=\sqrt{ } \mathrm{S}_{\text {LogOR }}^{2} \ldots \ldots \ldots \ldots \ldots . . .7
\end{aligned}
$$

\section{Meta Analytic Procedures}

Individual study effect sizes calculated in this sample were weighted to account for differences in precision based upon study-to-study sample size variance. Effect sizes from studies with larger samples provide more precise estimates of the population value than effect sizes produced by studies with smaller samples (Lipsey \& Wilson, 2001). If a meta-analysis were to simply average study effect sizes together, metrics produced by small studies would contribute as much to the mean as would those produced by larger, more precise studies. To correct for this imbalance, each study's effect size was weighted using the inverse of the squared standard error (i.e., the effect size variance; Lipsey \& Wilson, 2001). The variance is used because larger variances correspond to less precise effect size estimates (i.e. smaller studies), and the weight is commonly known as the inverse variance weight. Calculation of the inverse variance weight for the raw mean difference effect size is shown in formula 3.8 and for the log odds ratio in formula 3.9:

$$
\begin{aligned}
& W_{D}=\frac{1}{\mathrm{~S}^{2}}=\quad \frac{\mathrm{n}_{1}}{\frac{1}{2}} \frac{\left(\mathrm{n}_{2}\right) \ldots \ldots \ldots \ldots \ldots . .3 .8}{\left(\mathrm{n}_{1}+\mathrm{n}_{2}\right)} \\
& W_{\mathrm{LogOR}}=\underline{1}=\underline{\operatorname{abcd}} \ldots \ldots \ldots \ldots . .3 .9 \\
& \mathrm{~S}^{2}{ }_{\text {LogOR }} \quad \mathrm{ab}(\mathrm{c}+\mathrm{d})+\mathrm{cd}(\mathrm{a}+\mathrm{b})
\end{aligned}
$$




\section{Weighted Effect Size}

The practice of weighting effect sizes is important to obtaining a better estimate of the population effect size. It is generally accepted practice that individual effects should be weighted based upon the number of participants in the study prior to averaging the sample's effects (Lipsey \& Wilson, 2001). Once studies were weighted, the overall weighted average effect size, was computed using formula 3.10:

$$
\left.\mathrm{ES}=\frac{\sum\left(w_{i}\right.}{\sum w_{i}} \underline{\mathrm{ES}}_{i}\right) \ldots \ldots \ldots \ldots \ldots \ldots .10
$$

where $\sum\left(w_{i} \mathrm{ES}_{\mathrm{i}}\right)$ is the sum for all studies of the product of each studies' weight by its effect size, and $\sum w_{i}$ is the sum of all studies' weights.

Finally, a 95\% confidence interval was computed for each of the weighted average effect sizes produced (i.e. for GPA and for retention). The confidence interval for the mean effect size indicates the range within which the population mean is likely to fall. $95 \%$ confidence intervals were computed using formulas 3.11 for the standard error mean effect size and 3.12 for the $95 \%$ confidence interval:

$$
\begin{aligned}
& \mathrm{SE}_{\mathrm{ES}} \quad \frac{\sqrt{ } 1}{\sum w_{i}} \ldots \ldots \ldots \ldots \ldots \ldots . . .11 \\
& 95 \% \mathrm{CI}=1.96\left(\mathrm{SE}_{\mathrm{ES}}\right) \ldots \ldots \ldots \ldots .12
\end{aligned}
$$

where $\sum w_{i}$ is the sum of all studies' weights.

The value obtained through formula 3.11 is then added to and subtracted from the weighted mean effect size to produce the $95 \%$ confidence interval. The confidence interval is helpful in indicating the precision of the estimated mean effect size. If the confidence interval does not include zero, then the hypothesis that the association 
between variables in the population was zero should be rejected (Cohen, 2007). A direct z-test, shown in formula 3.13, can also be used to test the null hypothesis.

\section{Unit of Analysis}

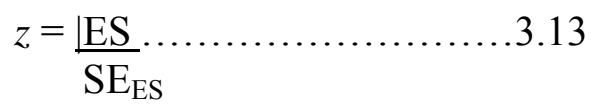

For this analysis, the independent sample was the unit of analysis. For most studies effect size information was reported for the overall sample. In these cases, each study contributed one independent sample to the analysis. Samples are considered independent if subjects do not overlap. If studies only reported findings for two or more non-overlapping sub-groups (such as commuter students vs. residents) it contributed more than one independent sample to the meta-analysis.

The shifting unit of analysis method (Cooper, 2010) was employed to identify what was an independent estimate of effect. For example, a study could examine the effect of extended orientation first year seminars on the first year GPA of academically prepared versus academically underprepared students. This study would contribute only one effect size to the meta-analysis as the effects for prepared and underprepared students would be averaged. When testing for the possible moderating effect of academic preparation, however, that study would contribute two effect sizes; one to each level (prepared vs. unprepared) of that moderating variable.

\section{Moderator Analysis}

A common criticism of meta-analysis is its inclusion of studies of varying degrees of quality (Lipsey \& Wilson, 2001). There are several ways to address this issue. Many quality measurement scales have been developed and are often used. However, there have been several well-founded criticisms of these tools (Conn \& Rantz, 2003). For 
example, Valentine and Cooper (2008) state that these "tools tend to (a) be insufficiently operational, (b) rely on arbitrary post-hoc decision rules, and (c) result in a single number to represent a multidimensional construct," (p. 130). Similarly, it is often the case that even a priori definitions of quality based upon study or design characteristics do not offer objective or consistent assessments of the quality of studies (Conn \& Rantz, 2003). A more objective strategy is to include studies of differing quality and address resultant issues through moderator analysis (Cooper, 1998).

Homogeneity analysis was used in this quality assessment to judge whether or not sampling error alone accounts for variance between effect size estimates or whether factors inherent to individual studies also account for some of this variance (Lipsey \& Wilson, 2001). Because effect sizes are sample statistics and estimate population values they will vary between studies even if they estimate the same population value (Valentine, DuBois, \& Cooper, 2004). Factors such as sample size, institution type, course length, and the measurement of existing academic ability and preparation amongst entering students could all affect the variability observed between studies' effect size estimates in this analysis. Homogeneity analysis compares the amount of variance between sample studies' effect sizes with the amount of variance that would be expected given sampling error alone. The statistic produced by this test, $Q$, approximately follows a chi-square distribution with k-1 degrees of freedom (Lipsey \& Wilson, 2001). To compute the $Q$ statistic I followed the procedure outlined in Formula 3.14.

$$
Q=\sum w_{i}\left(\mathrm{ES}_{i}-\mathrm{ES}\right)^{2} \ldots \ldots \ldots \ldots \ldots \ldots \ldots . .14
$$

where $w_{i}$ is the weight for an individual study, $\mathrm{ES}_{i}$ is the mean effect size for an individual study, and ES is the mean effect size for all studies in the sample. 
If $Q$ is shown to be statistically significant then the null hypothesis of homogeneity is rejected. This means that the variability between study effect sizes is greater than what would be expected given random sampling error alone (Lipsey \& Wilson, 2001). In the case of a statistically significant $Q$ individual moderator variables will be tested in order to identify systemic sources of variance between study effect sizes caused by issues related to study design and characteristics.

\section{Fixed Vs. Random Effects}

Finally, a choice was made between the fixed and random effects error models. This choice centers on assumptions regarding whether or not studies in the sample are measuring the same population effect. In a meta-analysis using the fixed-effect model's operating assumption is that studies included in the sample are estimating the same population value. Therefore, when using this model variance between effect sizes is assumed to be a product of sampling error alone. The random effects model, on the other hand, assumes that variance in the study is present due to both random sampling error and variability at the study level (Borenstein, et al., 2009). The most important issue in determining whether to use fixed or random effects is the nature of the research question(s) guiding the meta-analysis. If one wishes to make inferences that apply only to the studies being analyzed the fixed effects model is the appropriate choice. However, if the goal of synthesis is to generalize beyond the studies in a particular sample the random effects error model should be used (Hedges \& Vevea, 1998).

Meta-analyses have increasingly employed random effects models in recent years (Conn \& Rantz, 2003) as it produces more widely generalizable findings than does the fixed-effects model (Hedges \& Vevea, 1998). The random effects model was employed 
in this meta-analysis. This choice was made in the context guiding purpose of this study: To move the examination of extended orientation first year seminars beyond single institution studies and broaden understanding of this critical educational intervention and its effect on key metrics of student success. 


\section{CHAPTER IV}

\section{RESULTS}

\section{Search Outcomes}

The electronic literature search described in Chapter Three uncovered a total of 3,180 potentially relevant studies. An announcement on the NRC listserv as well as a direct request to its staff produced another six studies for review. Finally, pertinent journals and conference archives identified in Chapter Three provided an additional 7,732 studies for review. In total I screened the titles and abstracts of 10,918 studies. Of this initial group, 130 studies were identified as eligible for full text screening. The full text analysis of these 130 research reports yielded 45 studies which were eligible for inclusion in the final meta-analytic sample (Shown in Table 2). Of these, 15 were academic journal articles, 23 were dissertations, and seven were conference papers or reports from the NRC.

The studies appeared or were published between 1984 and 2013 and the base year researchers began collecting data ranged from 1979 to 2008 . Of the 45 studies in the sample, 11 measured cumulative first term GPA, 21 measured cumulative first year GPA, and 43 measured first-to-second year retention. The 102 independent samples in this study were based on data from 126,522 students. 


\begin{tabular}{|c|c|c|c|c|}
\hline \multicolumn{5}{|l|}{$\begin{array}{l}\text { Table } 2 \\
\text { Meta-Analytic Sample }\end{array}$} \\
\hline First Author (Year) & $\mathrm{N}$ & Cohort Year(s) & Carnegie Classification & Outcomes \\
\hline Beal (1998) & 1913 & 96 & Doctorate-Granting & Retention \\
\hline Behrman (1984) & 150 & 79 & - & $\begin{array}{l}\text { Retention } \\
\text { First Year } \\
\text { GPA }\end{array}$ \\
\hline Bitz & & & - & Retention \\
\hline Blackett (2008) & 336 & 04,05 & - & $\begin{array}{l}\text { Retention } \\
\text { First Year } \\
\text { GPA }\end{array}$ \\
\hline Brunelle-Joiner (1999) & 311 & 97 & Doctorate-Granting & $\begin{array}{c}\text { Retention } \\
\text { First Term } \\
\text { GPA } \\
\text { First Year } \\
\text { GPA }\end{array}$ \\
\hline Burgette (2009) & 1193 & 01 & Doctorate-Granting & Retention \\
\hline $\begin{array}{l}\text { Cambridge-Williams } \\
\text { (2013) }\end{array}$ & 590 & 02 & Doctorate-Granting & Retention \\
\hline & & & & $\begin{array}{l}\text { First Term } \\
\text { GPA }\end{array}$ \\
\hline Carstens (2000) & 658 & 95,97 & Master's & $\begin{array}{l}\text { Retention } \\
\text { First Year } \\
\text { GPA }\end{array}$ \\
\hline Cavote (2007) & 713 & 99 & Doctorate-Granting & Retention \\
\hline Chartriand (2012) & 4,212 & $04,05,06,07$ & Doctorate-Granting & Retention \\
\hline Clark (2011) & 435 & 99 & Doctorate-Granting & $\begin{array}{l}\text { Retention } \\
\text { First Year } \\
\text { GPA }\end{array}$ \\
\hline Craig (1994) & 2,929 & $89,90,91,92$ & Master's & $\begin{array}{l}\text { Retention } \\
\text { First Year } \\
\text { GPA }\end{array}$ \\
\hline Davis (1992) & 552 & $84,85,86$ & Master's & $\begin{array}{l}\text { Retention } \\
\text { First Year } \\
\text { GPA } \\
\text { First Term } \\
\text { GPA }\end{array}$ \\
\hline $\begin{array}{l}\text { Davis-Underwood } \\
\text { (1994) }\end{array}$ & 108 & 98 & Doctorate-Granting & $\begin{array}{l}\text { First Year } \\
\text { GPA }\end{array}$ \\
\hline Douthett (1998) & 6,790 & 98 & Doctorate-Granting & $\begin{array}{l}\text { First Year } \\
\text { GPA }\end{array}$ \\
\hline Fidler (1996) & 19,816 & $\begin{array}{l}86,87,88,89 \\
90,91,92,93\end{array}$ & Doctorate-Granting & Retention \\
\hline Frysinger (1998) & 876 & $92,93,94$ & Doctorate-Granting & $\begin{array}{c}\text { Retention } \\
\text { First Year } \\
\text { GPA }\end{array}$ \\
\hline
\end{tabular}




\begin{tabular}{|c|c|c|c|c|}
\hline \multicolumn{5}{|c|}{ Table 2 Cont. } \\
\hline First Author (Year) & $\mathrm{N}$ & Cohort Year(s) & Carnegie Classification & Outcomes \\
\hline Green (2010) & 804 & 07,08 & Baccalaureate College & Retention \\
\hline Helbig (2004) & 1,890 & 99,00 & Master's & Retention \\
\hline Hollins (2004) & 10,005 & 99,01 & Doctorate-Granting & $\begin{array}{l}\text { Retention } \\
\text { First Year } \\
\text { GPA } \\
\text { First Term } \\
\text { GPA }\end{array}$ \\
\hline House (1998) & 1,210 & $\begin{array}{c}87,88,89,90 \\
91\end{array}$ & Doctorate-Granting & Retention \\
\hline Jackson (2005) & 4,132 & 01,02 & Doctorate-Granting & Retention \\
\hline Janz (2004) & 2,064 & 02 & Master's & Retention \\
\hline Lang (2006) & 1,362 & 98 & Doctorate-Granting & $\begin{array}{l}\text { Retention } \\
\text { First Term } \\
\text { GPA }\end{array}$ \\
\hline Lashley (2005 & 3,364 & & Baccalaureate College & Retention \\
\hline $\begin{array}{l}\text { McMillan-Haron } \\
\text { (2003) }\end{array}$ & 2,314 & 00 & Doctorate-Granting & Retention \\
\hline & & & & $\begin{array}{l}\text { First Year } \\
\text { GPA }\end{array}$ \\
\hline Miller (2007) & 3,649 & 02,03 & $\begin{array}{c}\text { Master's } \\
\text { College/University }\end{array}$ & Retention \\
\hline Nottingham (1989) & 155 & 87 & Doctorate-Granting & $\begin{array}{c}\text { Retention } \\
\text { First Term } \\
\text { GPA } \\
\text { First Year } \\
\text { GPA }\end{array}$ \\
\hline Rogers (2005) & 2,166 & 2005 & Doctorate-Granting & Retention \\
\hline Schnell (2000) & 1,856 & $91,92,93,94$ & Doctorate-Granting & $\begin{array}{c}\text { Retention } \\
\text { First Term } \\
\text { GPA } \\
\text { First Year } \\
\text { GPA }\end{array}$ \\
\hline Shanley (1990) & 2,776 & 79 & Doctorate-Granting & Retention \\
\hline Sidle (2009) & 862 & $93,94,95$ & Master's & Retention \\
\hline Spann (1991) & 685 & 89 & Master's & $\begin{array}{l}\text { Retention } \\
\text { First Year } \\
\text { GPA }\end{array}$ \\
\hline Sparks (2005) & 2,367 & $\begin{array}{c}95,96,97,98 \\
99,00\end{array}$ & Master's & Retention \\
\hline & & & & $\begin{array}{l}\text { First Year } \\
\text { GPA }\end{array}$ \\
\hline Starke (2001) & 99 & 86 & Master's & Retention \\
\hline
\end{tabular}




\begin{tabular}{|c|c|c|c|c|}
\hline & & Table 2 Cont. & & \\
\hline First Author (Year) & $\mathrm{N}$ & Cohort Year(s) & Carnegie Classification & Outcomes \\
\hline Stewart (1997) & 1,069 & 1995 & Doctorate-Granting & $\begin{array}{l}\text { Retention } \\
\text { First Term } \\
\quad \text { GPA }\end{array}$ \\
\hline teDuits (2007) & 3,489 & 05 & Doctorate-Granting & $\begin{array}{l}\text { Retention } \\
\text { First Term } \\
\quad \text { GPA }\end{array}$ \\
\hline Weissman (2008) & 1,166 & 03 & Doctorate-Granting & $\begin{array}{l}\text { Retention } \\
\text { Fist Year } \\
\text { GPA }\end{array}$ \\
\hline \multirow[t]{2}{*}{ Williford (2001) } & 30,203 & $\begin{array}{c}86,87,88,89 \\
90,91,92,93 \\
94,95\end{array}$ & Doctorate-Granting & Retention \\
\hline & & & & $\begin{array}{c}\text { First Year } \\
\text { GPA }\end{array}$ \\
\hline Yale (1999) & 89 & 98 & Baccalaureate College & $\begin{array}{l}\text { Retention } \\
\text { First Year } \\
\quad \text { GPA }\end{array}$ \\
\hline Yarbrogh (1993) & 256 & 92 & Doctorate-Granting & $\begin{array}{l}\text { Retention } \\
\text { First Year } \\
\text { GPA }\end{array}$ \\
\hline Yu (2012) & 1,125 & 07 & - & $\begin{array}{l}\text { Retention } \\
\text { First Term } \\
\text { GPA }\end{array}$ \\
\hline
\end{tabular}

Note. Carnegie Classifications as of January, 2014.

\section{Main Analyses}

To address this study's guiding questions I conducted three separate metaanalyses: one for first term GPA, a second for first year GPA, and a third for first-tosecond year retention. All three meta-analyses were conducted using random effects assumptions and, for each, a weighted mean effect size was computed along with a test for the homogeneity of effect sizes. The homogeneity test was used to assess whether the estimates of effect size in this sample appear to estimate the same population effect size. This analysis allows one to judge whether or not sampling error alone accounted for variance between effect size estimates or whether factors inherent to individual studies 
also accounted for some of this variance (Lipsey \& Wilson, 2001). In addition to the homogeneity tests, several variables were examined in order to identify systemic sources of variance (moderators) between study effect sizes which might have been caused by issues related to study design and characteristics.

For each of the three outcomes a total of three methodological and seven FYS and sample-related moderators of effect size were examined in order to identify systematic sources of variance between study effect sizes associated with study design and characteristics related to first year seminars or study samples. Methodological moderators of effect size investigated in this study included sample size (i.e. whether the study's sample size fell above or below the median of all studies investigating each dependent variable of interest), whether the study used multiple cohorts in its sample, and whether authors used matching or statistical control techniques to control for group differences. FYS and sample-related moderators included institution type as described by the basic Carnegie Classification system, institution size, whether the course was instructed by a faculty member, a staff member, or a team of faculty and staff, whether the FYS being examined was new to the curriculum, whether the course included an explicit co-curricular component (i.e. a requirement to attend a certain number of campus events), whether the course included a peer mentor, and finally whether the sample was comprised of more than $75 \%$ white students. When possible, each of these ten potential moderators was tested to determine its impact on the relationship between FYS participation and first term GPA (seen in Table 4), first year GPA (seen in Table 6), and first-to-second year retention (seen in Table 8). 
Additional potentially impactful moderators such as institutional size and selectivity, students' socioeconomic status, residency status, and number of firstgeneration students in each sample were either not reported for a large percentage of studies (e.g. SES) or did not display enough variation in their observed values (e. g. institution size) to permit further exploration of their moderating effect. All variables included in moderator analyses were either inherently categorical in nature (i.e. whether an FYS course was new to the curriculum) or had small enough variation in observed values so as to make inclusion as a categorical variable necessary for meaningful analysis. Appendix E displays study-level classifications for each of the ten moderator variables.

\section{Meta-Analysis One: First Term GPA}

Eleven of the studies in the sample reported the outcome of first term GPA. Of these 11 studies, 10 had positive effect sizes (shown in Table 3). The weighted raw mean difference effect size under the random effects model was $D=0.16$, with a $95 \%$ confidence interval of \pm 0.09 , meaning that it ranged from a lower limit of 0.06 to an upper value of 0.25 . This difference was statistically significant $(z=3.27, p=.001)$. The test for homogeneity of effect sizes estimating this relationship was statistically significant $Q(10)=107.49, p<.001$, and exhibited considerable heterogeneity between studies, $I^{2}=89.77$. To investigate possible sources of heterogeneity I also performed several moderator analyses (shown in Table 4).

Sample size. I first tested the moderating effect of sample size. Studies were divided into groups which fell either above or below the median sample size for studies investigating each outcome. For the relationship between FYS participation and first term 
GPA, smaller studies had a slightly smaller effect size, $D=0.15(\mathrm{k}=6)$, than did larger studies, $D=0.16(\mathrm{k}=5)$. However, this difference was not statistically significant, $Q(1)$ $=.01, p=.93$.

Matching/control variables. I next investigated the moderating effect of either matching or statistical control techniques used by study authors to create more comparable groups. Studies were categorized as either having used control or matching or not and the moderating effect of these techniques was tested for each of three dependent variables in this study. Studies which used either matching or control to account for differences between groups yielded larger effects, $D=0.20(\mathrm{k}=7)$, than studies which did not use these procedures, $D=0.08(\mathrm{k}=4)$, but this difference was not statistically significant $Q(1)=1.8, p=.18$.

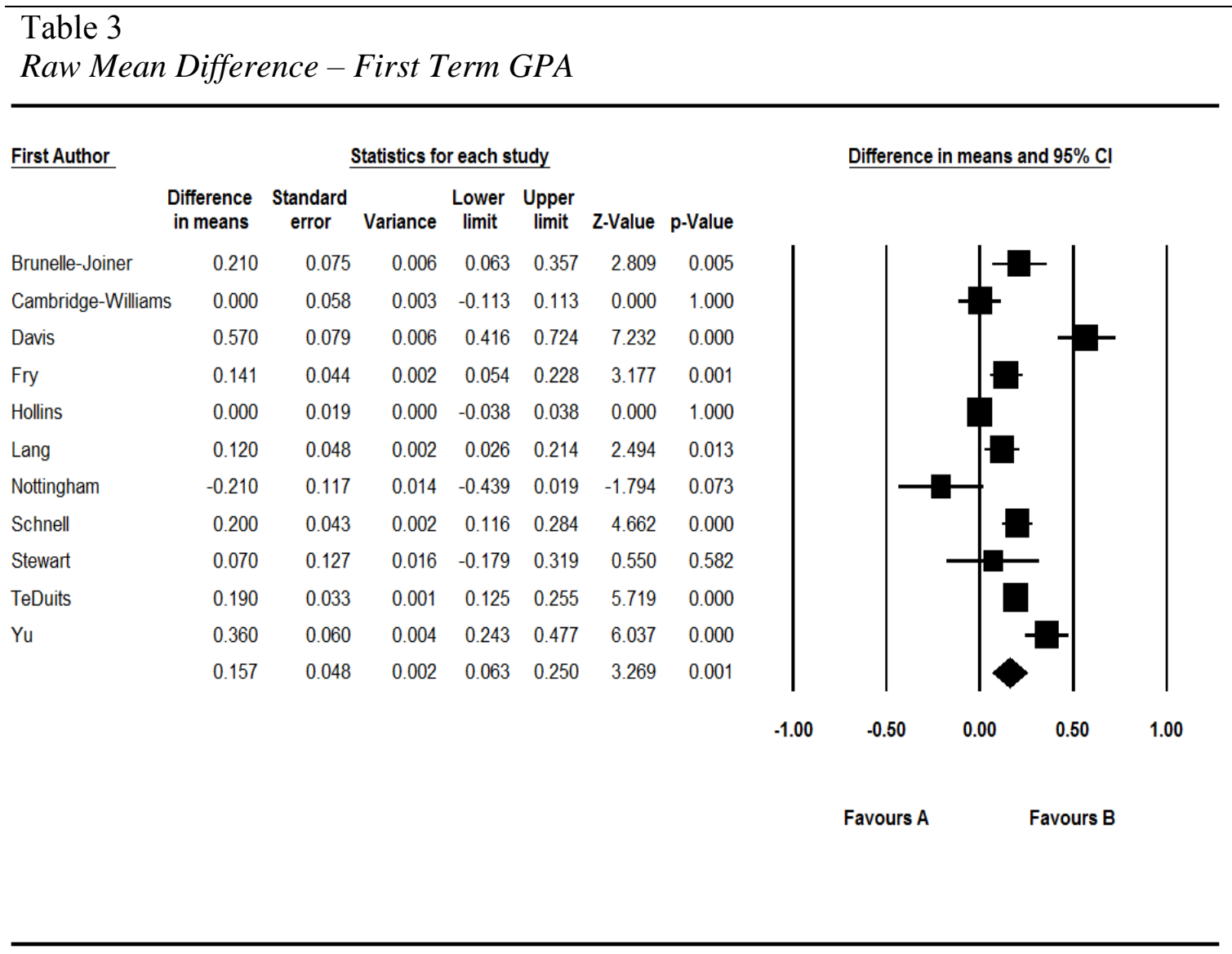


Multiple cohorts. I next investigated the moderating effect of the measurement of multiple cohorts of first year students on the magnitude of effect sizes. For the purpose of this analysis, studies were considered to have used multiple cohorts if they measured one or more of the three outcomes for at least two fall terms' entering group of freshmen. For first term GPA, studies which measured multiple cohorts yielded larger effects, $D=0.25(\mathrm{k}=3)$, than studies that did not, $D=0.13(\mathrm{k}=8)$, but this difference was not statistically significant, $Q(1)=0.66, p=.42$.

Instructor type. Many of the studies in this sample examined first year seminars which were taught by institution staff members or a combination of regular faculty and staff. Therefore, this analysis examined the impact of instruction by a faculty member has on effect sizes versus instruction by a staff member or a team of faculty and staff. For the first term GPA outcome, courses taught only by faculty yielded larger effects, $D$ $=0.23(\mathrm{k}=6)$, than courses taught by staff or teams of faculty and staff, $D=0.05(\mathrm{k}=5)$. This was a statistically significant difference, $Q(1)=5.09, p=.02$.

New course. I next tested whether new seminars moderated the relationship between course participation and effect size magnitudes. Courses which were being studied as a pilot or those which had been added to a college or university's curriculum for the first time were considered new and were compared to courses which had been in existence prior to the investigation being conducted in each study. New courses produced smaller effects, $D=0.14(\mathrm{k}=3)$, than did courses which were not new, $D=0.16(\mathrm{k}=8)$; however, this difference was not statistically significant, $Q(1)=0.02, p=.90$.

Co-Curricular component. I next investigated whether the inclusion of cocurricular components into seminars moderated estimates of effect sizes. For this 
analysis courses were determined to contain co-curricular components if students were required to interact with the campus community outside of the classroom. Co-curricular components could include requirements to attend campus events, a requirement to meet with a reference librarian, or a community service requirement.

Courses with no co-curricular component yielded larger effects, $D=0.15(\mathrm{k}=5)$, than did courses with a co-curricular aspect, $D=0.10(\mathrm{k}=4)$, but this difference was not statistically significant, $Q(1)=0.25, p=.62$.

Percent White. In order to investigate the possible moderating effects that differences in the racial/ethnic composition of samples might have had on effect size estimates I investigated the effect of the percent of white students in each study. Because many studies did not fully report demographics for their samples, and due to a lack of variability in the studies which did report information about race, studies were classified as either having a sample comprised of more or less than $75 \%$ white students. Samples which were comprised of greater than $75 \%$ white students yielded larger effects, $\mathrm{D}=0.11$ $(\mathrm{k}=4)$, than did samples comprised of less than $75 \%$ White students, $\mathrm{D}=0.09(\mathrm{k}=3)$; however, this difference was not statistically significant $Q(1)=0.08, p=.78$.

Peer mentor. Several studies in this sample investigated courses in which upperclassmen were included as a part of the seminar and served in an instructional support role and/or acted as a mentor for first year students in their transition from high school to college. Therefore I investigated whether the inclusion of a peer moderated the effects of FYS participation. For first term GPA, courses with a peer mentor yielded smaller effects, $D=0.10(\mathrm{k}=4)$, than did courses with without a peer mentor, $D=0.20$ $(\mathrm{k}=7)$. However, this difference was not statistically significant $(Q(1)=1.20, p=.28$ 


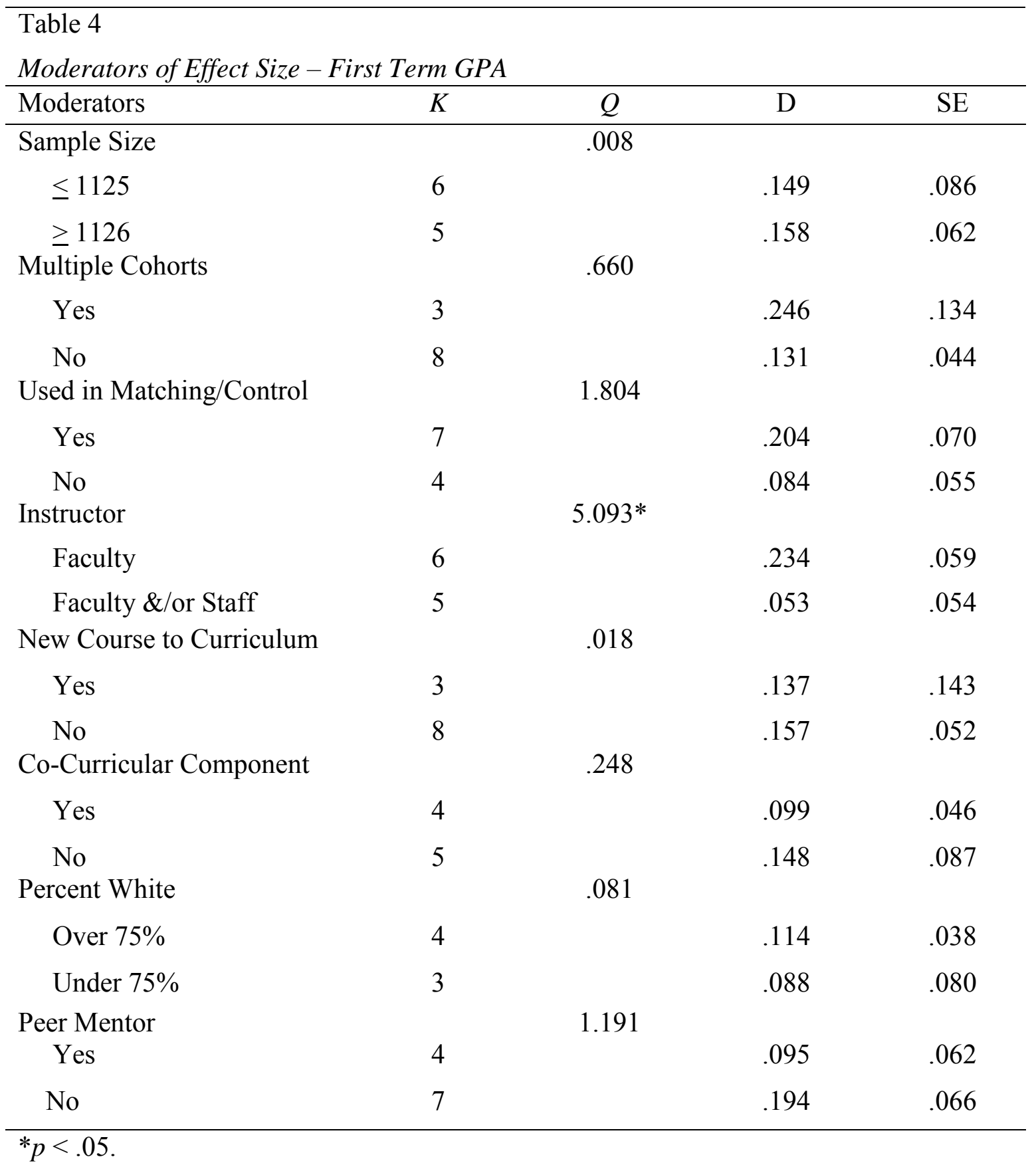

\section{Meta-Analysis Two: First Year GPA}

I next conducted a meta-analysis which investigated the effect of participation in extended orientation first year seminars and first year cumulative GPA. In this sample, 
21 studies reported a measure of first year GPA. Of these 21 studies, 13 had positive effect sizes (shown in Table 5). The weighted raw mean difference effect size under the random effects model was $D=0.09$, with a $95 \%$ confidence interval of \pm 0.06 meaning that it ranged from a lower limit of 0.03 to an upper limit of 0.14 . This difference was statistically significant $(z=3.12, p=.002)$. The test for homogeneity of effect sizes estimating the impact of FYS participation on first year GPA was statistically significant $Q(20)=345.44, p<.001, I^{2}=94.21$, and exhibited considerable heterogeneity between studies. Again, moderator tests were conducted to investigate possible systematic sources of heterogeneity (shown in Table 6).

Sample size. For the first year GPA outcome, larger studies were associated with smaller effects, $D=0.05(\mathrm{k}=11)$, than were smaller studies, $D=0.15(\mathrm{k}=10)$ but this relationship was not statistically significant, $Q(1)=1.73, p<.19$.

Matching/control variables. I next tested the moderating effect of the use of control or matching techniques on the outcome of first year GPA. Studies which employed matching or statistical control techniques to account for group differences yielded larger effects, $D=0.10(\mathrm{k}=13)$, than studies which did not, $D=0.08(\mathrm{k}=8)$. However, this difference was not statistically significant, $Q(1)=0.07, p=.80$.

Multiple cohorts. Those studies which measured multiple cohorts yielded small effects for the outcome of first year GPA, $D=0.08(\mathrm{k}=10)$, than did studies which measured only one cohort of first year students, $D=0.10(\mathrm{k}=11)$ but the difference was not statistically significant, $Q(1)=0.07, p=.80$.

Institution type. I next investigated whether the magnitude of effect size estimates were related to the type of institution at which the study took place. I 
investigated the moderating effect of a study taking place at a doctoral granting institution versus a master's college/university or baccalaureate institution. This test was not performed for first term GPA as all but one of the studies which measured this outcome was conducted at a Doctoral-Granting institution. There was sufficient variability in institution type between studies reporting first year GPA and retention to allow for analysis.

For the first year GPA outcome, studies conducted at master's or baccalaureate granting institutions produced larger effects, $D=0.18(\mathrm{k}=6)$, than did studies conducted at doctorate-granting institutions, $D=0.03(\mathrm{k}=14)$. This was not a statistically significant difference, $Q(1)=2.83, p=.09$.

Institution size. The analysis of institution size focused on possible moderating effects that differences in size between study sites may have had. The Carnegie classification system was used to identify large institutions as those with over 10,000 enrolled students. The effect of course participation at large institutions was compared to its effect at medium $(3,000-9,999$ students $)$ and small $(1,000-2,999)$ institutions. This test could not be performed for first term GPA as each of the studies which measured first term GPA took place at large institutions. Therefore, moderator analyses for institution size were performed only for the first year GPA and first-to-second year retention outcomes.

For first year GPA, studies conducted at small or mid-size institutions yielded larger effect sizes, $D=0.20(\mathrm{k}=4)$, than those conducted at large institutions, $D=0.06$ $(\mathrm{k}=16)$; however, this difference was not significantly significant $Q(1)=3.15, p<.08$. 
Table 5

Raw Mean Difference - First Year GPA

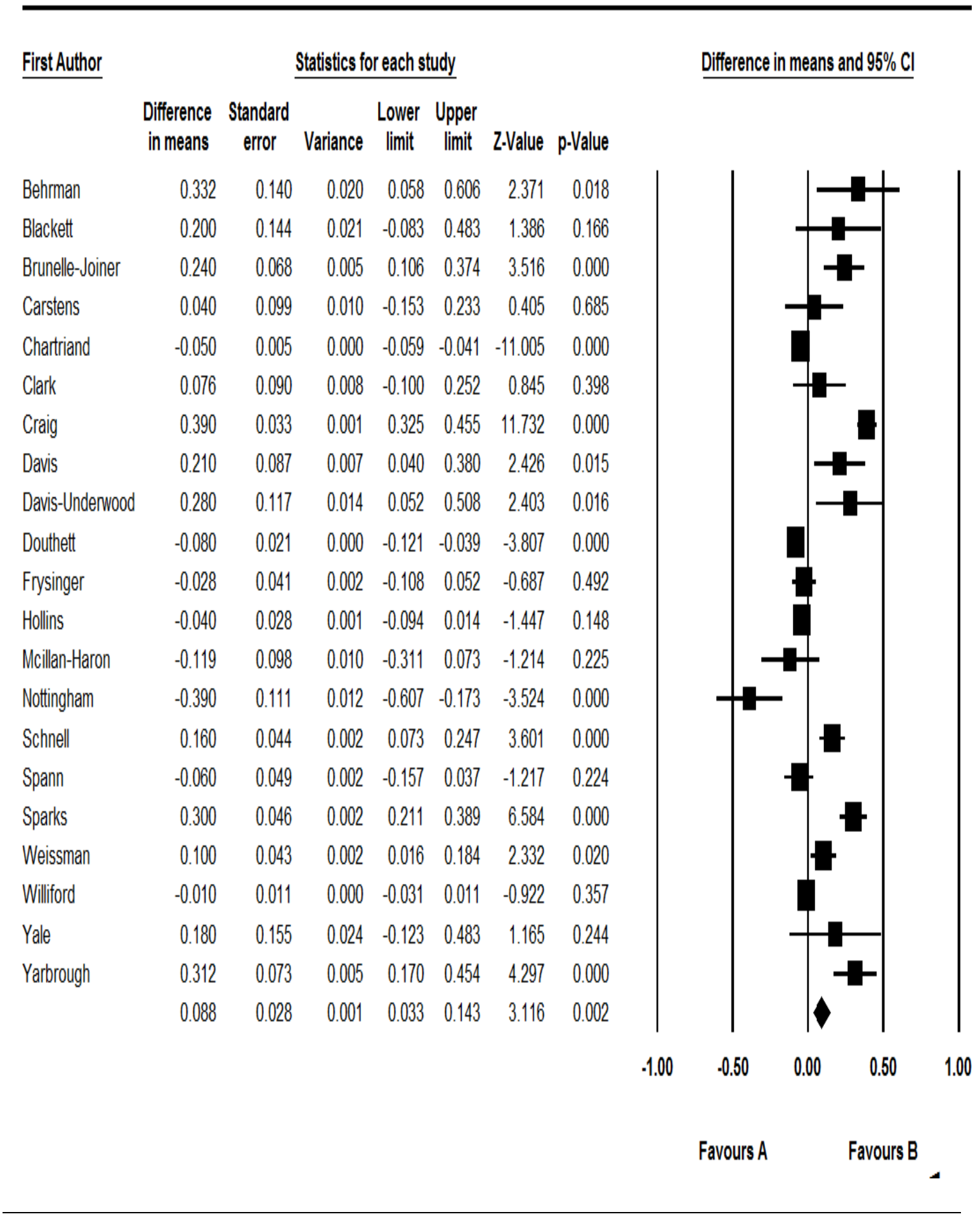


Instructor type. In this analysis, courses taught only by faculty yielded larger effects, $D=0.16(\mathrm{k}=10)$, than those taught by staff or teams of faculty and staff, $D=$ $0.04(\mathrm{k}=11)$; this difference was not statistically significant, however, $Q(1)=2.26, p=$ .13 .

Co-Curricular component. Courses with no co-curricular component yielded smaller effects, $D=0.07(\mathrm{k}=13)$, than did courses with a co-curricular aspect, $D=0.16$ $(\mathrm{k}=6)$. For first year GPA, the inclusion of co-curricular components in seminars was not significantly associated with effect size magnitude, $Q(1)=1.14, p=.29$.

Percent White. Samples comprised of greater than 75\% White students yielded smaller effect sizes, $D=0.04(\mathrm{k}=4)$, than did samples comprised of less than $75 \%$ White students, $D=0.14(\mathrm{k}=6)$; however, this difference was not statistically significant, $Q(1)$ $=0.63, p=.43$.

Peer mentor. Finally, for the outcome of first year GPA, courses with a peer mentor yielded smaller effects, $D=0.10(\mathrm{k}=5)$, than did courses which did use a peer mentor, $D=0.08(\mathrm{k}=16)$. This difference was not statistically significant, $Q(1)=0.04$, $p=.84$. 


\begin{tabular}{|c|c|c|c|c|}
\hline \multicolumn{5}{|l|}{ Table 6} \\
\hline Moderators & $k$ & $Q$ & $\mathrm{D}$ & SE \\
\hline Sample Size & & 1.726 & & \\
\hline$\leq 685$ & 11 & & .054 & .032 \\
\hline$\geq 686$ & 10 & & .148 & .064 \\
\hline Multiple Cohorts & & .065 & & \\
\hline Yes & 10 & & .081 & .035 \\
\hline No & 11 & & .098 & .058 \\
\hline Used Matching/Control & & .068 & & \\
\hline Yes & 13 & & .095 & .036 \\
\hline No & 8 & & .078 & .056 \\
\hline Institution Type & & 2.829 & & \\
\hline Doctorate-Granting & 14 & & .028 & .022 \\
\hline & 6 & & .181 & .088 \\
\hline $\begin{array}{l}\text { Master's/Baccalaureate } \\
\text { Institution Size }\end{array}$ & & 3.153 & & \\
\hline Large & 16 & & .062 & .029 \\
\hline Medium/Small & 4 & & .198 & .071 \\
\hline Instructor & & 2.259 & & \\
\hline Faculty & 10 & & .163 & .073 \\
\hline Faculty \&/or Staff & 11 & & .040 & .038 \\
\hline Co-Curricular & & 1.140 & & \\
\hline Component & & & & \\
\hline Yes & 6 & & .164 & .076 \\
\hline No & 13 & & .070 & .046 \\
\hline Percent White & & .631 & & \\
\hline Over $75 \%$ & 4 & & .041 & .067 \\
\hline Under $75 \%$ & 6 & & .138 & .102 \\
\hline Peer Mentor & & .040 & & \\
\hline Yes & 5 & & .097 & .048 \\
\hline No & 16 & & .084 & .045 \\
\hline
\end{tabular}




\section{Meta-Analysis Three: First-to-Second Year Retention}

Finally I conducted a meta-analysis which investigated the effect of participation in extended orientation first year seminars and first-to-second year retention. In total, 43 studies in the sample reported the outcome of first-to-second year retention. Of these 44 studies, 39 had positive effect sizes (shown in Table 7). The weighted log odds ratio under the random effects model was $O R_{L o g}=0.40$, with a $95 \%$ confidence interval of \pm 0.09 , meaning that it ranged from a lower limit of .30 to an upper limit of 0.49 . For ease of interpretation, the log odds ratio was converted back to odds ratio. When completing this transformation, the log Odds Ratio of 0.40 is transformed to an Odds Ratio of 1.49 . This means that, on average, the odds of persisting to the second year for those who participated in an FYS were approximately 1.5 times greater than the odds of persisting to the second year for those who did not participate in an FYS. This difference was statistically significant $(z=8.12, p<.001)$. The test for homogeneity of effect sizes estimating the effect of FYS participation on first-to-second year retention was statistically significant $Q(42)=275.05, p<.001$, and, while indicating less heterogeneity than either of the GPA outcomes, displayed considerable heterogeneity between studies, $I^{2}=84.73$. Finally, moderator tests were conducted to investigate possible systematic sources of heterogeneity (shown in Table 8).

Sample size. For the retention outcome, the effect of course participation on second year retention was stronger for larger studies, $O R_{\text {Log }}=0.44(\mathrm{k}=22)$, than for smaller studies, $O R_{L o g}=0.34(\mathrm{k}=21)$, though the difference was not statistically significant, $Q(1)=0.61, p=.44$. 
Multiple cohorts. For the first-to-second year retention outcome, studies which measured multiple cohorts were related to smaller effect sizes, $O R_{\text {Log }}=0.35(\mathrm{k}=18)$, than studies which did not measure multiple cohorts, $O R_{\text {Log }}=0.46(\mathrm{k}=25)$; this difference was not statistically significant, $Q(1)=1.26, p=.26$.

Matching/control variables. For the outcome of first-to-second year retention, those studies which used matching or control to account for group differences produced slightly smaller effects, $O R_{\text {Log }}=0.36(\mathrm{k}=21)$, than did those studies which did not use these techniques, $O R_{\text {Log }}=0.38(\mathrm{k}=20)$; however, this difference was not statistically significant, $Q(1)=0.02, p=.88$.

Institution type. Studies taking place at master's or baccalaureate institutions yielded larger effects, $O R_{\text {Log }}=0.42(\mathrm{k}=15)$ than those at doctorate-granting institutions, $O R_{\text {Log }}=0.36(\mathrm{k}=25)$, but this difference was not statistically significant, $Q(1)=0.21, p$ $<.65$.

Institution size. Studies at small or mid-size institutions produced larger effect sizes, $O R_{\text {Log }}=0.47(\mathrm{k}=10)$, than studies conducted at large colleges or universities, $O R_{\text {Log }}=0.35(\mathrm{k}=30)$ for the first-to-second year retention outcome. This difference was not statistically significant, $Q(1)=0.44, p=.51$.

Instructor type. For the outcome of first-to-second year retention, instruction by faculty was related to smaller effect sizes, $O R_{\text {Log }}=0.33(\mathrm{k}=25)$, than instruction by staff only or a team of faculty and staff, $O R_{\log }=0.49(\mathrm{k}=17)$, but this difference was not statistically significant, $Q(1)=1.82 . p=.18$. 
Table 7

Log Odds Ratio - First-to-Second Year Retention

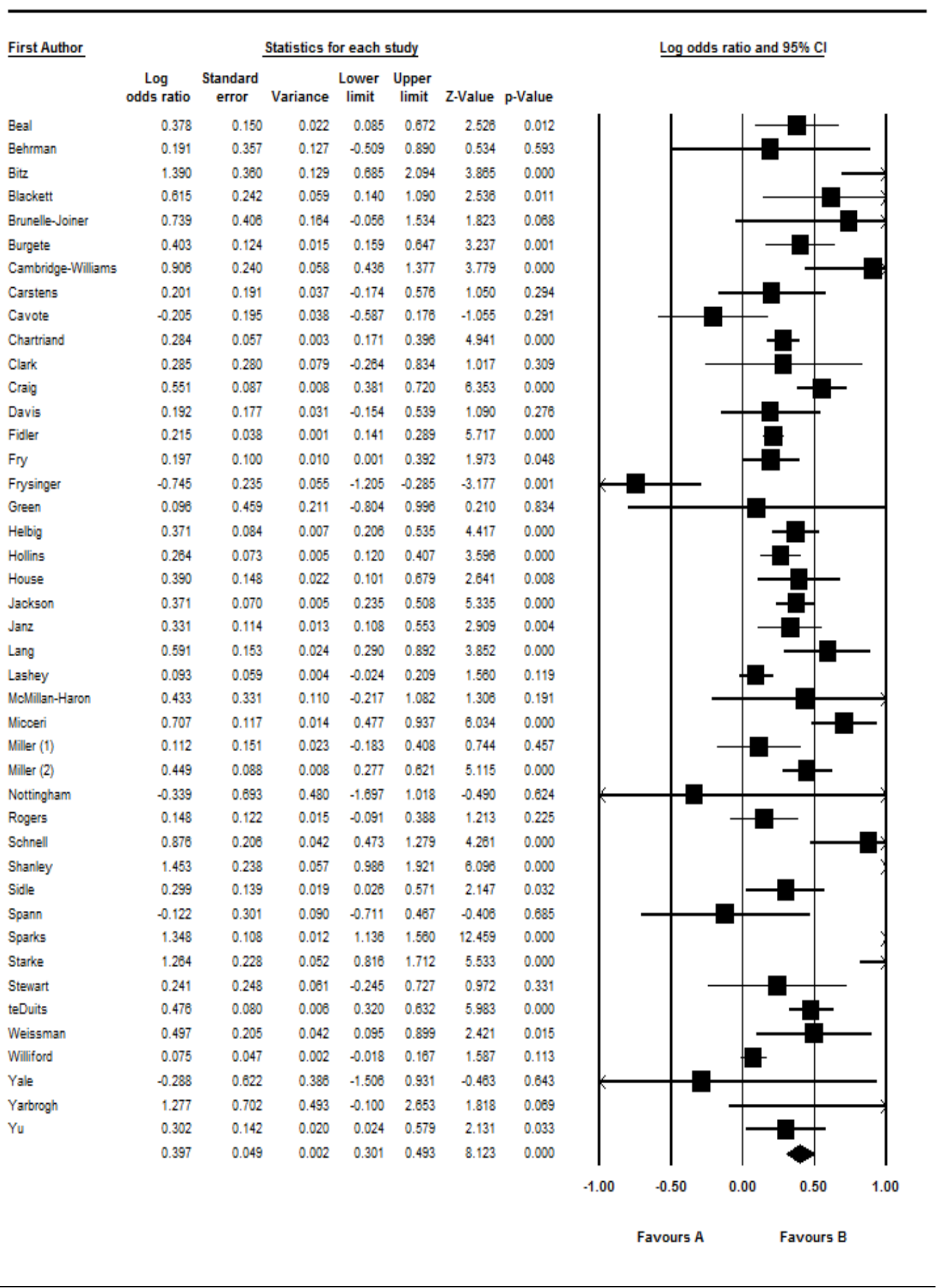


New course. In this analysis new courses produced smaller effects, $O R_{\text {Log }}=0.14$ $(\mathrm{k}=5)$, than courses which were not new, $O R_{\text {Log }}=0.47(\mathrm{k}=38)$; however, this difference was not statistically significant, $Q(1)=2.28, p=.13$.

Co-Curricular component. Next, courses which had a co-curricular aspect yielded larger effects, $O R_{\text {Log }}=0.52(\mathrm{k}=16)$, than courses which did not have cocurricular components, $O R_{L o g}=0.36(\mathrm{k}=19)$. This difference was not statistically significant, $Q(1)=1.77, p=.18$.

Percent White. Samples with more than $75 \%$ White students yielded smaller effects, $O R_{\text {Log }}=0.34(\mathrm{k}=8)$, than samples comprised of less than $75 \%$ White students, $O R_{\text {Log }}=0.61(\mathrm{k}=14) ;$ a statistically significant difference, $Q(1)=4.40, p=.04$.

Peer mentor. Finally, for the outcome of first-to-second year retention, courses using a peer mentor yielded smaller effects, $O R_{\text {Log }}=0.34(\mathrm{k}=9)$, than courses which did not use a mentor, $O R_{L o g}=0.40(\mathrm{k}=34)$. This difference was not statistically significant, $Q(1)=0.36, p<.55$.

\begin{tabular}{lcccc}
\hline $\begin{array}{l}\text { Table } 8 \\
\text { Moderators of Effect Size }- \text { First-to-Second Year Retention }\end{array}$ & & \\
\hline Moderators & $K$ & $Q$ & OR $_{\text {Log }}$ & SE \\
\hline $\begin{array}{l}\text { Sample Size } \\
\quad \geq 1211\end{array}$ & 22 & .605 & & \\
$\quad \leq 1210$ & 21 & & .437 & .059 \\
$\quad$ Multiple Cohorts & 18 & 1.257 & .339 & .101 \\
$\quad$ Yes & 25 & & .346 & .066 \\
$\quad$ No & & & .457 & .074 \\
$\quad \begin{array}{l}\text { Used Matching/Control } \\
\quad \text { Yes }\end{array}$ & 21 & .023 & & \\
$\quad$ No & 20 & & .364 & .053 \\
Institution Type & & .379 & .082 \\
$\quad$ Doctorate-Granting & 25 & & .361 & .054 \\
\hline
\end{tabular}




\begin{tabular}{lcccc}
\hline & Table 8 Cont. & & & \\
\hline Moderators & $K$ & $Q$ & OR $_{\text {Log }}$ & SE \\
\hline$\quad$ Master's/Baccalaureate & 15 & & .415 & .106 \\
Institution Size & & .439 & & \\
$\quad$ Large & 30 & & .354 & .047 \\
$\quad$ Medium/Small & 10 & & .471 & .170 \\
Instructor & & 1.818 & & \\
$\quad$ Faculty & 25 & & .327 & .051 \\
$\quad$ Faculty \&/or Staff & 17 & & .487 & .106 \\
New Course to Curriculum & & 2.276 & & \\
$\quad$ Yes & 5 & & .143 & .174 \\
$\quad$ No & 38 & & .471 & .051 \\
Co-Curricular Component & & 1.77 & & \\
$\quad$ Yes & 16 & & .523 & .090 \\
$\quad$ No & 19 & & .352 & .092 \\
Percent White & & $4.403 *$ & & \\
$\quad$ Over 75\% & 8 & & .344 & .062 \\
$\quad$ Under 75\% & 14 & & .611 & .111 \\
Peer Mentor & & .360 & & \\
$\quad$ Yes & 9 & & .342 & .079 \\
$\quad$ No & 34 & & .402 & .061 \\
\hline$* p<.05$. & & & &
\end{tabular}

\section{Group Differences}

It is critical to place the results of the three meta-analyses reported above in the context of a potentially significant threat to their validity. One of the seven criteria for inclusion of primary studies in this meta-analysis was that enrollment in seminars must have been open to all students at the institution(s), and that participation in the seminar must have been voluntary on the part of students. Therefore all FYS groups included in this study were comprised completely of volunteers. This constitutes a potential threat to the validity of this study.

This threat, referred to as volunteer bias, is usually viewed as a threat to the external validity of a study. That is, if those who choose to participate are systematically 
different than those who choose not to, it is unclear to who results can be generalized. In the studies in this review, however, the volunteer status of participants also has potential implications for internal validity. This means that if volunteers are different in meaningful ways than non-volunteers, it is unclear the extent to which causal inferences drawn from a study's results can be relied upon (Shadish, Cook, Campbell, 2002). Often, to account for the volunteer effect's threat to internal validity, participants are randomly assigned to conditions (treatment or control). This design does not eliminate the threat to external validity but the threat to the internal validity of studies can be reduced through random assignment (Shadish, Cook, Campbell, 2002). In the case of this study, however, participants are not randomly assigned and, therefore, volunteer bias remains a threat to both internal and external validity.

Because of this issue of non-random assignment in primary studies, it was important to understand how different or similar FYS and non-FYS groups were at baseline. In order to do so I coded for important student-level characteristics such as high school GPA, ACT or SAT scores, and first generation status. However, many of these variables were not widely reported in primary studies. When possible, information from studies that reported variables describing the baseline comparability of groups was coded in order to gain an understanding of groups' similarities. Although many studies did not provide adequate information to code for these variables, comparisons between groups (Appendix D) suggested that those students who chose to participate in FYS's most often had lower high school GPAs and ACT/SAT scores than their counterparts who chose not to participate. Even with this information, however, little is known about the overall baseline comparability of FYS and non-FYS groups in these meta-analyses. 


\section{FYS Grades}

Another possible limitation of this study lies in the inability to account for FYS course grades when calculating the outcomes reported. Particularly in terms of the two GPA outcomes, FYS grades can have an important effect on the magnitude and direction of effect size estimates. However, any impact that FYS grades have on the GPAs or retention will only be present for the FYS students.

Many of the criticisms of first year seminars in the past have called into question the academic rigor of these courses (e.g., Hunter \& Murray, 2007). Therefore it is reasonable to assume that students typically perform well in graded FYS's. Following this assumption, if average seminar grades are high, then students will see an increase in first term and first year GPAs as a direct result of taking the seminar itself and receiving the grade. So if differences between the FYS and non-FYS GPAs are small, as is the case in this study, then most or even the entire effect could be due to grades students received in the FYS itself and not larger gains in critical thinking skills.

Assume that the average grade achieved in seminars across studies was a B (3.0 on a four point scale). In a three-credit course and assuming the average student enrolled in 13.5 semester hours, this FYS grade can have a significant impact on the outcomes of these studies. The mean first term GPA for FYS students in the studies in this metaanalysis was 2.71. Therefore, eliminating the FYS grade would lower the mean GPA from 2.71 to 2.63 . Therefore, removing the FYS grade in this case would result in a decrease of .08 points in the overall average. That would move the average mean difference effect size from $D=.157$ to $D=0.07$; a dramatic decrease. 
Although the presence of FYS grades is a reality that is likely to affect each of the dependent variables in this study, it is not the seminar grades themselves that limits the findings of this study. Instead, as was the case in terms of the threat of volunteer bias, the true limitation lies in how little information is provided about the presence and impact of FYS grades in primary studies. Unfortunately, very few studies report any measure of FYS grades. This lack of information makes it difficult to assess the extent to which FYS grades do or do not bias the results of primary studies and subsequently these metaanalyses.

\section{Analyses for Publication Bias}

In order to test for the presence of publication bias in the sample, I conducted both funnel plot and trim and fill analyses for each of the three outcomes of interest. These tests were conducted using the random effects model only. Results of these analyses can be seen in Figures one through three. For both the first term GPA (shown in Figure 1) and the first year GPA (shown in Figure 2) outcomes, these tests resulted in the imputation of 0 studies to adjust for funnel plot asymmetry. This suggests that for the random effects model publication bias was not a serious threat to validity. However, for the studies which measured the impact of FYS participation on first-to-second year rates of retention, the trim and fill procedure (shown in Figure 3) resulted in the imputation of five studies. These imputations resulted in an adjustment from the mean log odds ratio effect size of $O R_{\text {Log }}=0.40$ to an unbiased mean log odds ratio effect size of $O R_{\text {Log }}=0.45$. Even with these imputations the effect of seminar participation was statistically significantly different from zero with the $95 \%$ confidence interval ranging from a low of 
0.36 to a high of 0.55 . Therefore, the trim and fill analyses indicated that publication bias was not a threat to the validity of the meta-analysis for any of three outcomes of interest.

\section{Summary of Meta-Analyses}

For each dependent variable, the overall mean effect size was statistically significantly different from zero, suggesting that FYS's, on average, are beneficial to the students who receive them. The effect sizes exhibited heterogeneity that was statistically significant and considerable in magnitude for all three outcomes. Moderator tests were conducted for each outcome to identify systematic sources of homogeneity in effect size estimates. Only two moderator tests were found to be significant, but there was no overlap in the patterns of statistical significance across the meta-analyses. For the outcome of first term GPA, instructor type was significantly related to effect size magnitude. None of the moderator tests were significantly related to effect size magnitude for the first year GPA outcome. And for the first-to-second year retention outcome only the percentage of white students in each sample was significantly related to effect size magnitude. Because there was no pattern to these results across metaanalyses, the considerable heterogeneity observed across the studies is still largely unexplained. 


\section{CHAPTER V \\ DISCUSSION}

National five-year postsecondary graduation rates have hovered near the $50 \%$ mark for decades (ACT, 2013). In response, a large body of research has investigated college student retention in an attempt to better understand student departure behavior in hopes of increasing the percentage of college students who obtain a degree (Braxton, 2000; Boden, 2012). Though no single solution has emerged from this work, wide agreement has formed surrounding the importance of the first year of college (Stratton, et al., 2008) as the majority of student departure has been attributed to individuals leaving their institutions at some point in their first year (Tinto, 1993). In fact, Terenzini (1987) attributed at least $50 \%$ of the overall dropout rate to freshman leaving at the end of their first year of study. The first year of college is critical not just in terms of who leaves but also who stays and who graduates. While graduation rates have remained stubbornly low for decades (ACT, 2013), about two-thirds of the students who persist to their second year complete a degree (Stratton, et al., 2008). Given this impact, "the first year is of particular importance to the continued discourse on college student retention in American higher education," (Kuep, 2006, p. 62).

In response, institutions have implemented a wide array of programmatic efforts designed to increase rates of first-to-second year retention (Adrande, 2008; Soldner, Lee, Duby, 1999; Dill, Gilbert, Hill, Minchew, Sempier, 2011). The most prevalent of these 
efforts is the first year seminar; a course intended to enhance the academic and/or social integration of first-year students by building skills essential for college success (Barefoot, 1992). Amongst the many models of first year seminars the extended orientation model is by far the most widely used as it is offered at a rate of $3: 1$ when compared with the next most popular model (Padgett, Hunter, Kilgo, 2013). Typically these courses focus on activities such as acquainting first year students with campus resources, the development of time management skills, academic and career planning, learning strategies, and assisting in common student development issues (Fidler, 1991). FYS's have been in existence since the late $19^{\text {th }}$ century and, after gaining in popularity during the 1970 's, are now used on nearly $90 \%$ of college campuses (NRC, 2009). Due to their prominence, FYS's have been amongst the most studied topics in all of higher education over the past several decades (Pascarella \& Terenzini, 1991). Historically, however, this research has been limited in its scope (Barefoot, 2000) and the preponderance of this work has been conducted at single institutions. These studies, while making important contributions, lack generalizability and provide only limited clues as to the overall effectiveness of extended orientation first year seminars (Padgett, Keup, \& Pascarella, 2013).

It was in this context that I developed this study in an attempt to address the limitations of previous research and to broaden the scope of inquiry into extended orientation first year seminars. In order to do so I used systematic review and metaanalysis to synthesize previous findings measuring the overall effectiveness of extended orientation first year seminars. Using these methods I investigated the effect of voluntary 
participation in extended orientation FYS's on (a) first year students' cumulative first term GPA, (b) first year GPA, and (c) rates of first-to-second year retention.

\section{Major Findings}

The results of each of the three meta-analyses I performed in this study are presented in Table 9. Overall, the mean effect size was statistically significantly different from zero for each of the three dependent variables: first term GPA, first year GPA, and first-to-second year retention. This suggests that FYS's, on average, are beneficial to the students who complete them. For each of the three outcomes, effect sizes exhibited heterogeneity that was statistically significant and considerable in magnitude. I attempted to identify systematic sources of this heterogeneity by conducting nine moderator tests. Only two variables were found to be statistically significant moderators of effect size magnitude. There was no overlap in the patterns of statistical significance across the meta-analyses, however, and because no pattern emerged across meta-analyses the heterogeneity between studies remains largely unexplained.

\section{Table 9}

Summary of Meta-Analytic Results

\begin{tabular}{lcccccc}
\multicolumn{1}{c}{ Outcome } & $\mathrm{K}$ & Mean Effect Size & $\mathrm{SE}$ & z-value & $Q$ & $I^{2}$ \\
\hline First term GPA & 11 & $D=.16$ & .05 & $3.27^{* * *}$ & $107.49^{* * *}$ & 89.77 \\
First year GPA & 21 & $D=.09$ & .03 & $3.12^{* *}$ & $345.44^{* *}$ & 94.21 \\
Retention & 45 & $O R_{\text {Log }}=.40$ & .05 & $8.12^{* * *}$ & $275.05^{* * *}$ & 84.73 \\
\hline
\end{tabular}

Note: ${ }^{* *} p<.01 .{ }^{* * *} p<.001$.

\section{First Term GPA}

The results of the first meta-analysis showed participation in an extended orientation FYS had a positive, $D=0.16$, and significant, $z=3.27, p<.001$, effect on first term GPA. This means that students who participated in first year seminars, on 
average, earned higher cumulative grade point averages at the end of their first term than did students who did not participate in a first year seminar. For example, the average first term GPA for control group members in this sample was approximately a 2.6 on a 4.0 scale. Therefore one could expect that participation in a first year seminar would, on average, result in an increase in the first term GPA from a 2.6 to a 2.76 .

\section{First Year GPA}

Participation in an extended orientation FYS also had a positive $(D=0.09)$, and statistically significant $(z=3.12, p=.02)$ effect on students' cumulative first year GPA. This means that, on average, students who participated in first year seminars earned higher cumulative grade point averages at the end of their first year of study than those students who did not participate in a first year seminar. The average first year GPA for control group students in this study was a 2.6 on a 4.0 scale. The results of this study suggest that, on average, participation in an FYS would increase a student's first year GPA from a 2.6 to a 2.69 . This effect was statistically significant.

\section{First-to-Second Year Retention}

Finally, participation in an extended orientation FYS had a positive $\left(O R_{\log }=\right.$ $0.40)$ and statistically significant $(z=8.12, p<.001)$ effect on students' rates first-tosecond year retention. To assist in interpretation, the log Odds Ratio of 0.40 was also transformed to an Odds Ratio of 1.49. This meant that, on average, the odds of persisting to the second year for those who participated in an FYS were approximately 1.5 times greater than the odds of persisting to the second year for those who did not participate in an FYS. 


\section{Moderators}

For each of the dependent variables I attempted to identify systematic sources of variance between studies' effect size estimates. Because effect sizes are sample statistics and estimate population values they will vary between studies even if they estimate the same population value (Valentine, DuBois, Cooper, 2004). Homogeneity analyses were used to judge whether sampling error alone accounted for the observed variance between effect size estimates or whether factors inherent to individual studies also account for some of this variance (Lipsey \& Wilson, 2001). Homogeneity tests were statistically significant for each of the three dependent variables. This indicated that the variability between effect sizes was larger than would be expected from sampling error alone.

In response to these significant homogeneity tests I investigated several variables in order to identify systematic sources of variance (moderators) between study effect sizes which might have been caused by issues related to study design and sample characteristics. For each of the three dependent variables I tested a total of three methodological moderators for their impact on the magnitude of effect sizes. I also conducted moderator tests for six variables related to individual seminars and study samples. The results of these tests should be interpreted with some degree of caution as their statistical power is relatively small. However, the differences between effect sizes in these moderator tests are relatively small and therefore this issue may not be of great concern. The results of these tests are summarized in Table 10.

A total of two variables were found to be statistically significant moderators of effect size magnitude. First, for the first term GPA outcome, instructor type was significantly related to effect size magnitude. Courses taught by faculty yielded larger 
effects than did courses taught by teams of faculty and staff or by staff alone. Secondly, for the first year GPA outcome, none of the moderator tests statistically significant. Finally, for the first-to-second year retention outcome, only the percentage of White students in each sample was statistically significant. That is, studies in which the sample was comprised of less than $75 \%$ White students yielded larger effects than did studies which had samples comprised of more than $75 \%$ White students. Overall, no pattern emerged from these moderator tests across meta-analyses and therefore the considerable heterogeneity observed across the studies remains largely unexplained.

\section{Implications}

In interpreting the results of this study it is critical to note that statistical significance does not imply practical significance. Due to the complex relationship between statistical and practical significance, the APA Task Force on Statistical Inference suggests the reporting and interpretation of effect sizes in both theoretical and practical contexts (Wilkinson \& APA Task Force on Statistical Inference, 1999). Therefore, effect sizes for each of the three dependent variables measured here must be contextualized not just in terms of their statistical significance but also in terms of what they mean for postsecondary institutions which are evaluating the effectiveness of current or future first year seminars.

Tests of statistical significance have been relied upon as the primary indicator of the overall importance of a study's results since the early $20^{\text {th }}$ century and during that time statistical significance has often been conflated with practical significance (Thompson, 2002). In many instances statistically significant results are considered important and non-significant results as an indication that a relationship between 
Table 10

Summary of Moderator Tests

\begin{tabular}{|c|c|c|c|c|c|c|c|c|c|}
\hline \multirow[b]{2}{*}{ Moderators } & \multicolumn{3}{|c|}{ First Term GPA } & \multicolumn{3}{|c|}{ First Year GPA } & \multicolumn{3}{|c|}{ Retention } \\
\hline & $k$ & $\mathrm{D}$ & $Q$ & $k$ & $\mathrm{D}$ & $Q$ & $k$ & $\mathrm{OR}_{\text {Log }}$ & $Q$ \\
\hline Sample Size & & & .008 & & & 1.73 & & & .61 \\
\hline Above Median & 6 & .15 & & 10 & .15 & & 22 & .44 & \\
\hline Below Median & 5 & .16 & & 11 & .05 & & 21 & .34 & \\
\hline Multiple Cohorts & & & .66 & & & .07 & & & 1.26 \\
\hline Yes & 3 & .25 & & 10 & .08 & & 18 & .35 & \\
\hline No & 8 & .13 & & 11 & .10 & & 25 & .46 & \\
\hline Matching/Control & & & 1.8 & & & .07 & & & .02 \\
\hline Yes & 7 & .20 & & 13 & .10 & & 21 & .37 & \\
\hline No & 4 & .09 & & 8 & .08 & & 10 & .38 & \\
\hline Institution Type & & & - & & & 2.83 & & & .21 \\
\hline Doctorate & - & - & - & 14 & .03 & & 25 & .36 & \\
\hline Master's/Bacc. & - & - & - & 6 & .19 & & 15 & .42 & \\
\hline Institution Size & & & - & & & 3.15 & & & .44 \\
\hline Large & - & - & - & 16 & .06 & & 30 & .35 & \\
\hline Medium/Small & - & - & - & 4 & .20 & & 10 & .47 & \\
\hline Instructor & & & $5.09 *$ & & & 2.26 & & & 1.82 \\
\hline Faculty & 6 & .23 & & 10 & .16 & & 25 & .33 & \\
\hline Faculty \&/or Staff & 5 & .05 & & 11 & .04 & & 17 & .49 & \\
\hline New Course & & & .02 & & - & & & & 2.28 \\
\hline Yes & 3 & .14 & & - & - & & 5 & .14 & \\
\hline No & 8 & .16 & & - & - & & 38 & .47 & \\
\hline Co-Curricular & & & .25 & & & 1.14 & & & 1.77 \\
\hline Yes & 4 & .10 & & 6 & .16 & & 16 & .52 & \\
\hline No & 5 & .15 & & 13 & .07 & & 19 & .35 & \\
\hline Percent White & & & .08 & & & .63 & & & $4.40^{*}$ \\
\hline Under $75 \%$ & 3 & .09 & & 6 & .14 & & 14 & .61 & \\
\hline Over $75 \%$ & 4 & .11 & & 4 & .04 & & 8 & .34 & \\
\hline Peer Mentor & & & 1.20 & & & .04 & & & .36 \\
\hline Yes & 4 & .09 & & 5 & .10 & & 9 & .34 & \\
\hline No & 7 & .19 & & 16 & .08 & & 34 & .40 & \\
\hline
\end{tabular}

Note: ${ }^{*} p<.05$.

variables is not important or that an intervention did not work. Statistical significance has been given such weight that many authors selectively report their results to focus on those which met the level of statistical significance. Further, researchers who find only non-significant results often do not submit their studies for publication (Chan, Hrobjartsson, Haahr, Gotzsche, \& Altman, 2004). The reliance on statistical significance 
to judge the overall significance of results is present amongst those who review for and edit academic publishing outlets as well. Dickersin and Min (1992) found that studies with statistically significant results are published up to $80 \%$ more often than studies with non-significant results. However, the tendency toward reliance on statistical significance as a proxy for the actual significance of studies' results has often come under criticism and many scholars (Kirk 1996; Fisher, 1925; Kelley, 1935; Thompson, 1993) have called for the concept of practical significance to be considered in interpreting the results of scientific research (Thompson, 2002).

It is critical to interpret the results of this study in terms of both statistical and practical significance. While statistical significance is an important tool in measuring the effectiveness of first year seminars, I also considered the practical impact that these courses have on first term GPA, first year GPA, and first-to-second year retention. This practical assessment adds to the statistical measurement of significance and considers the full context of the costs and overall benefit of using extended orientation first year seminars as tools to promote first year student success.

\section{Positive Effects}

The purpose of this study was to address a gap in the existing body of literature by moving beyond single institution studies of first year seminars and providing a broader lens through which to examine the effectiveness of this key first educational intervention. The results of each of the three meta-analyses I performed were both positive and statistically significant. These results support the trend in previous studies which has shown seminar participation to be tied to a multitude of positive first year outcomes (Pascarella \& Terenzini, 2005; Padgett, Keup, Pascarella, 2013). This study has shown 
first year seminars, and specifically the extended orientation model of first year seminars, to be positively associated with key outcomes related to first year student success.

The results of the three meta-analyses I performed align with the trend of previous research which has shown FYS participation to be related to first year success (Pascarella \& Terenzini, 2005) but this study also provides new information. To date, no metaanalysis has been conducted examining the effect of voluntary participation in extended orientation seminars at 4-year colleges and universities. The greatest benefit to this study and its use of meta-analysis is in its ability to produce higher powered results than have previously been achieved by the multitude of single-institution studies that have preceded it (Lipsey \& Wilson, 2001). From an empirical perspective, then, these results do not simply align with previous trends; instead they strengthen claims made as to the effectiveness of extended orientation first year seminars in promoting key first year student success outcomes. However, moving beyond a statistical analysis and considering further the practical impact of FYS participation leaves significant questions as to the practical effect of these courses.

\section{Practical Significance}

While the results of the meta-analyses I performed in this study broaden the generalizability of previous research investigating the effectiveness of extended orientation first year seminars, these results must be contextualized in terms of what they mean in practice. Therefore in this section I weigh the benefits of the use of these courses against the cost of implementing, administering, and assessing them. FYS's have become the most popular tool in institutions' efforts to stem first year student attrition and have recently been found to be in existence on nearly $90 \%$ of the college and 
university campuses in the United States (NRC, 2009). Given this prevalence it is important to provide full analysis of the impact they will have on students' lives and on institutions' continuous battle to shepherd students into their second year and beyond. This analysis also provided the lens through which questions regarding a possible overreliance on these courses arose.

Despite being statistically significant, the effect sizes yielded in each of the metaanalyses, particularly for the two GPA outcomes, are relatively small in practical terms. The weighted raw mean difference effect sizes of $D=.16$ and $D=.09$ for first term and first year GPA respectively must be evaluated carefully in terms of what practical impact they have on students' overall grade point averages. On a typical 4.0 scale, the effect sizes seen here would not result in a large practical increase in student GPAs. For example, moving from a letter grade of a B to a B + increases earned GPA points from 3.0 to 3.3. Given the two GPA effect sizes, participation in a first year seminar would not move students from a B to a B + average for either the first term GPA or first year GPA outcomes.

The chasm between statistical and practical significance is less dramatic for the retention outcome. In this case the odds of persisting to the second year for those who participated in an FYS were roughly 1.5 times greater than the odds of persisting to the second year for those who did not participate in an FYS. Again this effect is statistically significant but practically small. If, for example, an institution's cohort of 1,000 entering students was evenly divided into 500 FYS participants and 500 non-FYS participants and 425 or $85 \%$ of FYS participants were retained to their second year then approximately 395 or $79 \%$ of non-FYS participants would be retained to their second year as well. In 
this example this results in only a $6 \%$ increase in first-to-second year retention between FYS and non-FYS participants.

Though practical significance is perhaps more difficult to operationalize than statistical significance, the two concepts are of equal importance in the context of this study. First year seminars are resource intensive interventions. These courses require administrative resources to develop, maintain, and evaluate them as a part of an institution's curriculum. Each of these activities requires capital resources and can be just as intensive in terms of human resources. Administrative staff members are often required for the maintenance and evaluation of first year seminars. Seminars, of course, need instructors as well. As was the case in the sample used for this study, instructors can come from several levels of the university. Instructors can range from tenured full professors to adjunct part-time faculty. Staff members, usually those from an institution's student affairs function, often teach these courses as well, and in some instances teams of faculty, staff, and upper division students are team teach. Further, first year seminars in the traditional extended orientation model tend to have relatively small enrollments. This can means that course instructors must either teach a large number of seminars or that a large number of instructors must teach these courses. In most instances, then, the development, implementation, maintenance, and evaluation of first year seminars can include a relatively large number of faculty, staff, and students from numerous levels of an institution: a significant allocation of resources. It is appropriate, then, to evaluate the effectiveness of first year seminars in the context of these significant expenditures of fiscal and human resources. 
It is important to note that investigating first year seminars in the context of resource allocation would alter the questions that these studies address. When taking into account the amount of resources dedicated to these courses, studies would no longer address the effectiveness of these courses but would instead address their efficiency. Effectiveness can be defined as "being successful in producing a desired result or accomplishing set goals," (Norman-Major, 2010, p. 236). Efficiency, however, is defined as achieving the best possible value from scarce resources (Norman-Major, 2010). Therefore, evaluating the efficiency of first year seminars would measure the effect they have on outcomes such as GPA and retention in relation to the amount of resources allocated by institutions to the courses themselves. If, for example, an institution dedicated a large amount of either financial or human resources toward the development, implementation, and evaluation of a first year seminar, the relatively small effect sizes seen in this study might indicate that the seminars are inefficient. On the other hand, institutions which allocate few resources toward first year seminars might interpret the effects seen in this study as an indication that first year seminars are an efficient tool in promoting first year student success. An evaluation of overall course efficiency was not possible in this study as studies provided little if any information as to the cost of seminars. However, future studies could enrich our body of knowledge by accounting for the cost of first year seminars and evaluating their use in terms of both effectiveness and efficiency.

As there is broad agreement about the importance of the first year of college in the pursuit of degree attainment (Stratton, et al., 2008), first year interventions will undoubtedly remain a focus for postsecondary institutions of all types. The results of 
these meta-analyses, while all statistically significant, raise questions about the practical effectiveness of the first year seminar. Certainly the argument here is not that these courses are ineffective or that they should be discarded as a first year intervention. Instead, these results suggest that careful evaluation of the practical effects of these courses on student outcomes must be continued. During a time in which nearly $90 \%$ of all postsecondary institutions offer a first year seminar of some kind (Tobolowsky \& Associates, 2008), it is critical that work such as this study not be seen simply as further proof that we need to look no further for interventions to increase student success during the transition from high school to college. There is a danger in the over-interpretation of this study's results leading to an even greater overreliance on first year seminars as a silver bullet. This type of interpretation should be avoided. This is particularly true as, when considered in their full context, this study suggests that FYS's may, on average, produce very small practical effects. Perhaps the most appropriate future direction for the field, then, is to continue to engage in systematic evaluation of current and future first year seminars while also creating and testing new interventions that might have an even greater impact on the success of first year students.

The evaluation of practical and statistical significance is one which is especially important for administrators whom may be evaluating the effectiveness of seminars on their campuses. Though I assert that the statistically significant results in this study do not necessarily suggest practically significant results, this is a distinction that should truly be made in the context of individual institutions. While the results of this study should act as a catalyst for college and university administrators to evaluate the effectiveness and efficiency of their own seminars, the question of whether an institution's first year 
seminar should continue to be used cannot be answered by this study. The small, positive gains seen here in first-to-second year retention, for example, might be satisfactory for institutions with an already high rate of return to the second year. An institution which has historically struggled with very low first-to-second year retention rates, however, might wish to explore options that could have a greater impact on retention. Similarly, for institutions which commit few financial and personnel resources to these courses, small positive gains in these outcomes may be seen as satisfactory. However, institutions which have designed more resource intensive courses might consider results such as those in this study inefficient and be prompted to explore alternative first year initiatives. Therefore, while the results of this meta-analysis call into question the practical significance of participation in extended orientation first year seminars, it must be left to the faculty and administrators of individual institutions to interpret the true impact of these courses on their campuses.

\section{Exploring Alternatives}

It is possible to interpret the results of this study as evidence that extended orientation first year seminars are relatively ineffective as first year interventions. Given the resources dedicated to these courses and the prevalence of their use, the effect sizes seen in this study prompt questions about the future of FYS's as the primary tool used by institutions in an attempt to raise rates of first-to-second year retention. While these courses have been shown to have positive effects on key student outcomes (Pascarella \& Terenzini, 2005), it is troubling that such a large number of institutions rely upon an intervention which produces such small practical effects as their primary means of assisting students in the most critical step in their journey toward degree attainment. 
Perhaps the heavy reliance on FYS's is fueled in party by more than a century of history (Jones \& Braxton, 2010) and decades of research investigating their impact on students. However, first year seminars have been joined in the curriculum by many first year interventions which have also been shown to be effective. These include learning communities, orientation programs, student development interventions, peer advising, mentoring networks, "welcome" activities, workshops and tutorials, residence life programming, and many others (Kuep, 2006; Andrade, 2008). Each of these should be considered in the future as institutions continue to look for means of easing the transition from high school to college. This list, of course, is not exhaustive nor is it static. Institutions must also be willing to create and implement their own first year interventions in the continued search for tools that will promote first year success.

Whether institutions examine existing first year seminars, implement alternative first years interventions, or create new programming designed to assist first year students, it is critical that empirical evidence such as the results I have presented in this study be used to stem an overreliance on first year seminars. These courses have been in use for generations and have been shown to positively impact students (Pascarella \& Terenzini, 2005). However, the meta-analyses I performed for this study suggest that these effects are of limited practical significance. Therefore, not only must first year seminars continue to be thoroughly investigated, but perhaps a search must begin for a more effective alternative. 


\section{Limitations \& Directions for Future Research}

\section{Volunteer Bias}

As I detailed prior to presenting the meta-analytic results in Chapter Four, the greatest limitation of this study lies in the threat of volunteer bias. All experimental groups included in this sample were comprised wholly of volunteers, and all comparison groups were formed from the pool of non-volunteers. Because of this, questions about the baseline comparability of volunteers and non-volunteers (FYS and non-FYS students) were raised.

It is likely that those who volunteered to participate in seminars are different in meaningful ways than the population from which the overall samples were drawn. If volunteer participants are systematically different than their non-volunteer counterparts than only a subset of the population was represented in the sample. If this is the case, then a significant threat exists to the validity of inferences drawn from a sample in which volunteer bias is present. If, for example, students who enrolled in seminars were more academically prepared and were better able to integrate because of individual social or psychological traits then any positive effect observed may not be due seminar participation. Instead, effects could be present because the students who took these courses were more likely to earn higher grades and persist at higher rates simply due to their own academic strength and social adaptability. In this was the case, volunteer bias would threaten the validity of results.

I initially planned to conduct moderator tests using key academic variables in order to help identify systematic differences between FYS participants and nonparticipants. However, many of these variables were not widely reported in primary 
studies. This meant that instead of testing for the difference between effect size magnitudes of studies which controlled for high school GPA and those that did not, for example, I was only able to test for the differences between studies which used matching or control at all to account for group differences and those that did not. This more generic distinction reflects the lack of specificity in primary study reporting and provides little in the way of addressing the treat of volunteer bias. When conducting these tests, however, both of the GPA outcomes showed that studies which used these techniques produced larger effects than did studies which did not. This suggests that there might be differences between groups. Unfortunately too little is known about the baseline comparability of FYS and non-FYS groups in these meta-analyses. Therefore the threat of volunteer bias remains significant in this study and must be considered when interpreting its results.

Future research in this vein should consider the impact of this type of bias and work to eliminate or at least mitigate its impact. When possible, primary studies should employ true experimental designs in which students are randomly assigned to either participate in a seminar or not participate in a seminar. If this is not possible, quasiexperimental designs should be employed whereby FYS groups are compared against non-FYS groups which have been formed via a matching procedure. If matching techniques are not used to account for group differences than some measure of statistical 'control' should be employed in order to limit the impact that systematic differences between groups on key variables might have on study results. Finally, in future metaanalyses those studies which do not limit FYS participation to voluntary enrollment should be included for analysis. It would be interesting, for example, to develop a meta- 
analysis in which the overall effects of voluntary FYS's are compared against noncompulsory FYS's. Study designs such as these would help to limit the impact that systematic differences between volunteer participants and non-participants might have had on the results of this study.

\section{Quality of Reporting}

The issues of volunteer bias and FYS grades detailed above pose threats to the validity of this study because of a lack of information presented in both cases. This unfortunately was the norm rather than the exception. During the initial coding of this systematic review I intended to code for many social and academic variables which would have allowed for greater specificity in understanding the effect of first year seminars as well as in identifying variables which may moderate the relationship between course participation and effect size magnitudes. These variables included measures such as socioeconomic status, first-generation status of students, and at-risk status. I also wished to code demographic details of samples used for this study and to determine what, if any, variables were used to measure the comparability of groups or to create more comparable groups for comparison. Unfortunately, however, many of these variables were not reported in primary studies. For example, less than half of the studies in the sample reported demographic details and only two of the studies reported any measure of socioeconomic status. Similarly, only three studies reported the first-generation status of students, and only three reported any designation of students' risk status. It was also often unclear what, if any, variables were used to control for baseline differences in FYS and non-FYS groups. Given these realities, some degree of specificity was lost in the meta-analyses conducted for this study. Therefore, future research could benefit from 
more robust and clearer reporting of details which could allow for greater refinement of our understanding of how well seminars work and what might make them work better.

There are three major suggestions for future studies investigating the effectiveness of extended orientation first year seminars. Each of these suggestions is primarily methodological in nature and each works to address some of the gaps in the current body of literature and those gaps not addressed by this study.

\section{Scope and Scale}

The primary purpose of this study was to address a perceived gap in the existing literature lefty by a multitude of single-institution studies. None of the 46 studies included in this analysis was conducted at multiple institutions. This limits the external generalizability and the power of previous results. The research that has been conducted over the past several decades has been clear: first year seminars produce relatively small, positive effects on several measures of first year student success. As consistent as these results have been, the design of the studies conducted have been nearly as consistent. Most studies are single institution projects which follow a single cohort of first year students for one to five years. This study attempted to move beyond the information provided by these single institution studies through the use of meta-analysis. Perhaps this does not go far enough in this effort, however. Instead, the field would benefit from the inclusion of studies which take place at several institutions, over the course of several years. This would broaden the knowledge which has been produced to date and would provide a stronger rationale upon which to base decisions regarding the inclusion of first year seminars into curricula. Large scale, longitudinal studies would certainly be more resource intensive and would require cooperation on the part of several disparate parties. 
However, given the reliance upon these courses and the resources they require the benefit of stronger, more generalizable results produced by these studies would likely outweigh the costs.

\section{Study Design}

Perhaps the greatest need in future research is for the increased use of quasiexperimental and experimental designs. The criterion that students must have volunteered to enroll in these courses precluded the inclusion of true experimental designs in this sample. However, I investigated how many studies which would have otherwise been included in my sample were eliminated due to this criterion. I first reexamined my initial screening guide and evaluated again all studies which were eliminated by the voluntary enrollment requirement. None of these studies would have been included by eliminating the voluntary enrollment criterion and none were experimental designs. I also performed a second version of my electronic literature search in an attempt to find any experimental studies that were eliminated from my sample based upon the voluntary criterion. I reproduced the full literature search but eliminated all keywords in the "Study Design" category and replaced them with the search term "Experiment*". This yielded over 300 studies for review. None of these met my inclusion criteria, even with the voluntary enrollment requirement eliminated. Certainly the results of this cursory search do not imply that no study has ever been conducted which investigated the effectiveness of first year seminars while employing an experimental design. There are likely experimental studies conducted which investigate other models of first year seminars or are conducted at 2-year institutions. It is also possible that my search strategy missed experimental designs that would have met the 
inclusion criteria set forth for this study. However, it is clear that experimental designs are lacking in this line of inquiry.

There are likely several reasons for this. For example, many first year seminars are an engrained part of institutions' curriculum and, therefore, not offering it to a randomly selected group of students would require the approval of a large number of campus constituents. Also, many administrators may already be convinced of the benefits of these courses and could harbor ethical concerns over withholding a treatment which they believe to be effective. Finally, in the process of recruiting, registering, and orienting a larger number of incoming students each year, randomly assigning students to these courses would likely cause logistical concerns regarding class and program schedules. These concerns aside, however, the field would greatly benefit from the continued use of quasi-experimental designs, and particularly from the incorporation of experimental designs. Through the use of these methods we could begin to better understand the true effects of this ubiquitous and critical first year intervention.

\section{Mixed Methods}

The final recommendation for future research is again rooted in methodological concerns. As I stated previously, greater specificity and breadth of reporting is needed to improve future studies. The field, practitioners and academicians alike, would also benefit from increased use of the quasi-experimental and particularly experimental designed studies. These suggestions, while likely to improve the overall quality of the literature, are rooted in a post-positivist paradigmatic world view and assume that future work should be quantitatively orientated. Instead of focusing solely on measuring the effectiveness of first year seminars only through quantitative work, the field would be 
enriched by studies that take a true mixed methods approach to investigating first year interventions.

The advantages of this type of research design have been well argued. Broadly, mixed methods approaches to investigating complex problems provide both the objectivity of quantitative work as well as the contextual dynamism of qualitative research (Cresswell, 2003). Approaching the study of first year seminars from a mixed methodological standpoint would allow for clear answers to questions such as whether course participation increases second year retention while also addressing less strictly defined questions. By adding a qualitative component to the types of studies included in this sample, future research would lend a voice to the people most intimately involved with first year seminars.

A mixed methods approach to the study of first year seminars would allow for greater nuance in addressing questions that surround such a critical first year intervention. Quantitative studies such as those included in this study's sample allow researchers, administrators, and faculty to investigate how effective FYS course participation is in increasing measurable outcomes such as GPA and first-to-second year retention. However, purely quantitative studies do not provide an avenue for the voices of those involved. By conducting qualitative studies alongside quantitative we might better understand why some courses work and some don't. This type of work would allow students, faculty, staff, and administrators to provide insight into the effectiveness of the courses by sharing their experiences. These voices might bring to light aspects of these courses that are either effective or not that quantitative work by itself would not be able to identify. It is critical, then, that future work include both quantitative and qualitative 
investigations of first year seminars and, when possible, that they are done together. By taking this step, the field can move beyond asking if these courses work or not and begin to ask why.

\section{Conclusion}

The systematic review and meta-analyses conducted in this study lend clear statistical support to decades of research which has shown participation in extended orientation first year seminars to be positively associated with many key educational outcomes. This study was an attempt to move the investigation of this intervention forward by conducting a broader study than had been previously completed. Although there were statistically significant results for all three outcomes, the key takeaway from this study is the lack of practically significant effects produced by seminar participation. Although statistical significance is important, the practical effects of course participation displayed in this study are small. This distinction is critical in an environment in which institutions of all types are expending large amounts of fiscal and human resources to adopt first year seminars as their primary tool to transition students from high school into postsecondary education. With more than $90 \%$ of institutions in the United States reporting the use of a first year seminar of some type on their campus, we are already in danger of overreliance on these courses as the one best tool to get students to their second year and eventually to degree attainment. To fight this tendency, future research must critically evaluate these courses in a much fuller context in an attempt to move our work beyond questions of whether these courses work and move toward questions of whether the first year seminar is the best we can do for our students. 


\section{REFERENCES}

Adelman, C. (1998). Women and men of the engineering path: A model for analyses of undergraduate careers (Document No. PLLI 98-8055). Washington, DC: U.S. Department of Education and National Institute for Science Education.

Adelman, C. (1999). Answers in the tool box: Academic Intensity, attendance patterns, and bachelor's degree attainment. Washington, DC: U.S. Department of Education.

ACT (2001, February). "National college dropout and graduation rates, 1999." [http:www.act.org/news].

American College Testing (2005). National collegiate retention and persistence to degree rates. Retrieved from http://www.act.org/research/policymakers/pdf/retain 2004.pdf

American College Testing (2013). 2013 Retention/Completion Summary Tables. Retrieved from https://www.act.org/research/policymakers/pdf/13retain_trends.pdf

American College Testing (2013). National collegiate retention and persistence to degree rates. Retrieved from http://www.act.org/research/policymakers/pdf/retain_2013.pdf 
American College Testing (2005). National collegiate retention and persistence to degree rates. Retrieved from http://www.act.org/research/policymakers/pdf/retain_2004.pdf

Anderson, E. C., \& McGuire, W. (1997). Academic advising for student success and retention: A strengths perspective. In M. Hovland, E. Anderson, W. McGuire, D. Crockett, J. Kaufmann, \& D. Woodward (Eds.), Academic advising for student success and retention. Iowa City, IA: Noel-Levitz.

Andrade, M. S. (2008). Learning communities: Examining positive outcomes. Journal of College Student Retention, 9(1), 1-20.

Astin, A. W. (1984). Student involvement: A developmental theory for higher education. Journal of College Student Development, 40(5), 518-529.

Astin (1993). What matters in college? Four critical years revisited. San Francisco: Jossey-Bass.

Bank, B., Slavings, R., \& Biddle, R. (1990). Effects of peer, faculty, and parental influences on students' persistence. Sociology of Education, 63, 209 - 225.

Barefoot, B. O. (1992). Helping first-year college students climb the academic ladder. Report of a national survey of freshman seminar programming in American higher education. Unpublished doctoral dissertation. College of William and Mary. Williambsburg, VA.

Barefoot, B. O. (2000). The first-year experience: Are we making it any better? About Campus, 12-18. 
Barefoot, B. O. (2004). Higher education's revolving door: Confronting the problem of student drop out in US colleges and universities. Open Learning, 19(1), 9-18.

Baum, S., Ma, J., Payea, K. (2013). Education pays 2013: The benefits of higher education for individuals and society. New York: The College Board.

Bean, J. P. (1980). Dropouts and turnover: The synthesis and test of a causal model of student attrition. Research in Higher Education, 12(2), 155-187.

Bean, J. P. (1985). Interaction effects based on class level in and explanatory model of college student dropout syndrome. American Educational Research Journal, $22(1), 35-64$.

Berger, J. B., \& Lyon, S. C. (2005). Past to present: A historical look at retention. In A. Seidman (Ed.), College student retention: Formula for student success (pp. 1-30). Westport, CT: Praeger Publishers.

Boden, G. T. (2012). Retention and graduation rates: Insights from an extended longitudinal view. Journal of College Student Retention: Research, Theory \& Practice, 13(2), 179-203.

Borenstein, M., Hedges, L. V., Higgins, J. P. T., Rothsetin, H. R. (2009). Introduction to meta-analysis. Hoboken, NJ: John Wiley \& Sons Inc.

Bowden, R. B. (2007). Evolution of responsibility: From in loco parentis to ad meliora vertamur. Education, 127(4), 480-489. 
Braxton, J. M. \& Hirschy, A. S. (2005). Theoretical developments in college student departure. In A. Seidman, (Ed.), College student retention: Formula for student success (pp. 61-87). Westport, CT: Greenwood Press.

Braxton, J. M., Milem, J. F., \& Sullivan, A. S. (2000). The influence of active learning on the college student departure process: Toward a revision of Tinto's theory. The Journal of Higher Education, 71(5), 569-590.

Cabrera, A., Castaneda, M. B., Nora, A., \& Hengstler, D. (1992). The convergence between two theories of college persistence. The Journal of Higher Education, 63(2), $143-164$.

Cabrera, A. F., Nora, A., \& Castaneda, M. B. (1993). College persistence: Structural equations modeling test of an integrated model of student retention. The Journal of Higher Education, 64(2), 123-139.

Carnevale, A. P., Rose, S. J., Cheah, B. (2009). The college payoff: Education, occupations, lifetime earnings. Washington, DC: Center on Education and the Workforce.

Chang, M. (1999). Does racial diversity matter?: The educational impact of a racially diverse undergraduate population. Journal of College Student Development, 40, $377-395$.

Coll, K. M., \& Stewart, R. A. (2008). College student retention: Instrument validation and value for partnering between academic and counseling services. College Student Journal, 42(1), 41-56. 
Colton, G. M., Connor, U. J. Jr., Shutlz, E. L., \& Easter, L. M. (1999). Fighting attrition: One freshman program that targets academic progress and retention for at-risk students. Journal of College Student Retention, 1(2), 147-162.

Conley, D. (2007). Redefining college readiness. Eugene, OR: Educational Policy Improvement Center.

Conn, V. S., Rantz, M. J. (2003). Research methods: Managing primary study quality in meta-analysis. Research in Nursing \& Health, 26, $322-333$.

Cook, B., Pullaro, N. (2010). College graduation rates: Behind the numbers. Washington, DC: American Council on Education.

Cooper, H. (1998). Synthesizing research: A guide for literature reviews (3rd ed.) Thousand, CA: Sage.

Cooper, H. (2010). Research synthesis and meta-analysis: A step-by-step appropch. Thousand Oaks, CA: SAGE.

Copeland, K. J., \& Levesque-Briston, C. (2011). The retention dilemma: Effectively reaching the first-year university student. Journal of College Student Retention, 12(4), 485-515.

Crissman, J. L. (2002). The impact of clustering first year seminars with English composition courses on new students' retention rates. College Student Retention, $3(2), 137-152$.

Cross, K. (1998, July/August). Why LCs? Why now? About Campus, 4-8. 
Cuccaro-Alamin, S. (1997). Findings from Condition of Education 1997: Postsecondary persistence and attainment (No. NCES 97-984). Washington, CD: U.S> Department of Education, Office of Educational Research and Improvement, National Center for Education Statistics.

Cunningham, A. (2006). The broader societal benefits of higher education. Retrieved November 4, 2013 from http://jcu.edu/academic/planassess/planning/files/Planning\%20articles/Broader\%2 0Social\%20Benefits.pdf

Cuseo, J. (2010). The empirical case for the first-year seminar: Promoting positive student outcomes and campus-wide benefits. In The first-year seminar: Researchbased recommendations for course design, delivery, and assessment. Dubuque, IA: Kendall/Hunt.

Davis, B. O. (1992). Freshman seminar: A broad spectrum of effectiveness. Journal of the Freshman Year Experience 4(1): 79-94.

Deeks JJ, Higgins JPT, Altman DG (editors). Chapter 9: Analysing data and undertaking meta-analyses. In: Higgins JPT, Green S (editors). Cochrane Handbook for Systematic Reviews of Interventions. Version 5.0.1 [updated September 2008]. The Cochrane Collaboration, 2008. Available from www.cochrane-handbook.org.

Delen, D. (2012). Predicting student attrition with data mining methods. Journal of College Student Retention, 13(1), 17-35. 
Demetriou, C. \& Schmitz-Sciborski, A. (2011). Integration, motivation, strengths and optimism: Retention theories past, present and future. In R. Hayes (Ed.), Proceedings of the 7th National Symposium on Student Retention, 2011, Charleston. (pp. 300-312). Norman, OK: The University of Oklahoma.

DesJardins, S. L., Kim, D-O., Rzonca, C. S. (2002-2003). A nested analysis of factors affecting bachelor's degree completion. Journal of College Student Retention, 4(4), 407-435.

DeWitz, S. J., Woolsey, L. M., Walsh, B. W. (2009). College student retention: An exploration of the relationship between self-efficacy beliefs and purpose in life among college students. Journal of College Student Development, 50(1), 19-34.

Dickersin, K., \& Min, Y. (1992). Factors influencing publication of research results. Journal of American Medical Association, 267(3), 374-381.

Dill, A. L., Gilbert, J. A., Hill, J. P., Minchew, S. S., \& Sempier, T. A. (2011). A successful retention program for suspended students. Journal of College Student Retention, 12(3), 277-291.

Dresch, S. P. (1983). College Enrollment: Retrospect and Prospect. In J. Froomkin, (ed.), The Crisis in Higher Education. New York: Academy of Political Science.

Durkheim, E. (1961). Suicide (J. Spaulding \& G. Simpson, trans). Glencoe: The Free Press. 
Duval, S., \& Tweedie, R. (2000). A nonparametric 'trim and fill' method of accounting for publication bias in meta-analysis. Journal of the American Statistical Association, 95, $89-98$.

Dwyer, J. O. (1989). “A Historical Look at the FreshmanYear Experience.” In M. L. Upcraft, J. N. Gardner, and Associates (eds.), The freshman year experience: Helping students survive and succeed in college. San Francisco: Jossey-Bass.

Emiers, M., Pike, G. (1997). Minority and nonminority adjustment to college: Differences or similarities? Research in Higher Education, 38, 77 - 97.

Engberg, M. E., \& Mayhew, M. J. (2007). The influence of first-year "success" courses on student learning and democratic outcomes. Journal of College Student Development, 48(3), 241-258.

Feldman, K. A., \& Newcomb, T. M. (1969). The impact of college on students. San Francisco: Jossey-Bass

Fidler, P. (1991). Relationship of freshman orientation seminars to sophomore return rates. Journal of the Freshman Year Experience, 3 (1), 7-38.

Fleis, J. L., \& Berlin, J. A. (2009). Effect Sizes for Dichotomous Data. In H. Cooper, L. Hedges, J. Valentine (Eds.), The handbook of research synthesis and metaanalysis (pp. 237 - 256). New York, NY: Russell Sage Foundation.

Gardner, J. N. (2001, October). Why, academic deans and department heads are so critical to the success of first-year students. Paper presented at the Fall Institute of the Policy Center on the First Year of College, Asheville, North Carolina. 
Gekoski, N., \& Schwartz, S. (1961). Student mortality and related factors. Journal of Educational Research, (54), 192-194.

Glass, G. V., Mcgaw, B., Smith, M., L. (1981). Meta-Analysis in social research. Thousand Oaks, CA: Sage.

Godwin, G. J., \& Markhan, W. T. (1996). First encounters of the bureaucratic kind: Early freshman experiences with a campus bureaucracy. Journal of Higher Education, 67(6), 660-691.

Gordon, V., \& Grites, T. J. (1984). The freshman seminar course, helping students to succeed. Journal of College Student Personnel, 25 (4), 315-320.

Greenhalgh, T. (1997), 'Papers that Summarise Other Papers (Systematic Reviews and Meta-analyses)', British Medical Journal, 315(7109), 672-675.

Hanger, M. A., Goldenson, J., Weinberg, M., Schmitz-Sciborski, A., Monzon, R. (2012). The bounce back retention program: One-year follow-up study. Journal of College Student Retention, 13(2), 205-227.

Heaney, Al, \& Fisher, R. (2011). "Supporting Conditionally-Admitted Students: A Case Study of Assessing Persistence in a Learning Community." Journal of the Scholarship of Teaching and Learning, 11(1).

Hedges, L. V., Vevea, J. L. (1998). Fixed- and random-effects models in meta-analysis. Psychological Methods, 3(4), 486 - 504.

Hendel, D. D. (2007). Efficacy of participating in a first-year seminar on student satisfaction and retention. Journal of College Student Retention, 8(4), 413-423. 
Herzog, S. (2005). Measuring determinants of student return vs. dropout/stopout vs. transfer: A first-to-second year analysis of new freshmen. Research in Higher Education, 46(8), 883-928.

Higgins, J.P.T., Green, S, editors. Cochrane Handbook for Systematic Reviews of Interventions (2006). In: The Cochrane Library, Issue 4, 2006. Chichester, UK: John Wiley \& Sons, Ltd.

History of the first university seminar \& the university 101 program. (2013). Retrieved March 1, 2013 from http://www.sc.edu/univ101/aboutus/history.html

Holland, P., Stallings, J. D., \& Braxton, J. (2002). The fulfillment of expectations for college and student departure decisions. Journal of College Student Retention: Research, Theory, and Practice, 3(4), 381-396.

Hossler, D. (1984). Enrollment management: An integrated approach. New York: College Board.

Hossler, D., \& Bean, J. P. (1990). The strategic management of college enrollments. San Francisco: Josey-Bass.

Hunter, M. S. (2006). Lessons learned: Achieving institutional change in support of students in transition. New Directions for Student Services, 114, 7-15.

Hunter, M. S., \& Linder, C. (2005). First-year seminars. In M. L. Upcraft, J. N. Gardner, \& B. O. Barefoot (Eds.), Challenging and supporting the first-year student: A handbook for improving the first year of college (pp. 275-291), San Francisco, CA: Jossey-Bass. 
Hunter, M. S., \& Murray, K. A. (2007). New frontiers for student affairs professionals: Teaching and the first-year experience. New Directions for Student Services, 117, 25-34.

Institute for Higher Education Policy. (2005). The investment payoff: A 50-state analysis of the public and private benefits of higher education. Washington, DC: Author.

Jamelske, E. (2008). Measuring the impact of a university first-year experience program on student GPA and retention. Higher Education, 57, 373-391.

Jones, W. A., Braxton, J. M. (2010). Cataloging and comparing institutional efforts to increase student retention rates. Journal of College Student Retention: Research, Theory \& Practice, 11(1), 123-129.

Kiser, A. I. T., \& Price, L. (2008). The persistence of college students from their freshman to sophomore year. Journal of College Student Retention, 9(4), 421436.

Knight, W. E. (2003). Learning communities and first-year programs: Lessons for planners. Planning for Higher Educaiton, 31(4), 5-12.

Kuep, J. R. (2006). The impact of curricular interventions on intended second year reenrollment. Journal of College Student Retention, 7(1-2), 2006.

Kuh, G. D., Cruce, T. M., Shoup, R., Kinzie, J., Gonyea, R. M. (2008). Unmasking the effects on first-year college grades and persistence. The Journal of Higher Education, 79(5), 540-563. 
Lipsey, M. W., \& Wilson, D. B. (2001). Practical meta-analysis. Thousand Oaks, CA: Sage.

Maldonado, D. E. Z., Rhoads, R., \& Buenavista, T. L. (2005). The student-initiated retention project: Theoretical contributions and the role of self-empowerment. American Educational Research Journal, 42(4), 605-638.

Malveaux, J. What's at stake: The social and economic benefits of higher education. Challenging Times, clear choices: An action agenda for college access and success. National Dialogue on Student Financial Aid, Research Report no. 2. Washington, D.C.: Pathways to College Network, 2003

Murphy, R. O. (1989). Freshman year enhancement in American higher education. Journal of the Freshman Year Experience, 1(2), 93-102.

National Research Council. (2002). Learning and understanding: Improving advanced study of mathematics and science in U.S. high schools. Washington, DC: National Academy Press.

Norman-Major, Kristen. 2010. Balancing the four Es; or can we achieve equity for social equity in public administration? Journal of Public Affairs Education 17, no 2:233252.

Padgett, R., Hunter, S., \& Kilgo, C. (2011). Innovations in the first year seminar: Additional evidence. NASPA Proceedings, Philadelphia, PA. 
Padgett, R. D., Keup, J. R., \& Pascarella, E. T. (2013). The Impact of First-Year Seminars on College Students' Life-long Learning Orientations. Journal of Student Affairs Research and Practice, 50(2), 133 - 151.

Panos, R.J., \& Astin, A.W. (1968). Attrition Among College Students. American Educational Research Journal, 1, 57-72.

Pascarella, E. T. (1980). Student-faculty informal contact and college outcomes. Review of Educational Research, 50(4), 545-595.

Pascarella, E. T., \& Terenzini, P. T. (1991). How college affects students. San Francisco, CA: Jossey-Bass.

Pascarella, E. T., \& Terenzini, P. T. (2005). How college affects students: A third decade of research. San Francisco, CA: John Wiley \& Sons, Inc.

Peltier, G. L., Laden, R., Matranga, M. (1999). Student persistence in college: A review of research. Journal of College Student Retention, 1(4), 357 - 375.

Policy Center on the First Year of College. (2002) Second national survey of first-year academic practices 2002. Brevard, NC: Author.

Porter, S. R., \& Swing, R. L. (2006). Understanding how first-year seminars affect persistence. Research in Higher Education, 47(1), 89-109.

Price, J. L. (1977). The Study of Turnover. Ames: Iowa State University Press. 
Reason, R. D. (2009). An examination of persistence research through the lens of a comprehensive conceptual framework. Journal of College Student Development, $50(6), 659-682$.

Schrader, P. G., Brown, S. W. (2008). Evaluating the first year experience: Students' knowledge, attitudes, and behaviors. Jounal of Advanced Academics, 19(2), 310343.

Schnell, C. A., \& Doetkott, C. D. (2003). First year seminars produce long-term impact. Journal of College Student Retention, 4(4), 377-391.

Seymour, E., \& Hewitt, N. (1997). Talking about leaving: Why undergraduates leave the sciences. New York: Academic Press.

Smith, C. A. (2000). The relationship between institutional enrollment performance and enrollment management effectiveness factors. Journal of College Student Retention, 2(4), $367-377$.

Soldner, L., Lee, Y., \& Duby, P (1999). Welcome to the block: Developing freshman learning communities that work. Journal of College Student Retention, 1(2), 115129.

Spady, W. G. (1970). Dropouts from higher education: An interdisciplinary review and synthesis. Interchange, 1(1), 65-85.

Spady, W. G. (1971). Dropouts from higher education: Toward and empirical model. Interchange, 2(3), 38-62. 
St. John, E., Masten, C. (1990). Return on the federal investment in student financial aid: An assessment for the high school class of 1972. Journal of Student Financial Aid, 20, 4-23.

Stratton, L. S., O'Toole, D. M., Wetzel, J. N., (2008). A multinomial logit model of college stopout and dropout behavior. Economics of Education Review, 27, 319331.

Study Group on the Conditions of Excellence in Higher Education. (1984). Involvement in college: Realizing the potential of American higher education. A report of the National Institute of Education, U.S. Department of Education, Washington, DC: U.S. Government Printing Office.

Sutton, A. J. (2009). Publication Bias. In H. Cooper, L. Hedges, \& J. Valentine (Eds.), The handbook of research synthesis and meta-analysis (pp. 435 - 452). New York, NY: Russell Sage Foundation.

Swail, W. S. (1995). The development of a conceptual framework to increase student retention in science, engineering, and mathematics programs at minority institutions of higher education. Ed.D. dissertation: The George Washington University.

Swail, W. S. (2004). The art of student retention: A handbook for practitioners and administrators. Educational Policy Institute. Texas Higher Education Coordinating Board 20th Annual Recruitment and Retention Conference Austin, TX June 21, 2004. www.educationalpolicy.org 
Swail, W. S., Redd, K., \& Perna, L. (2003). Retaining minority students in higher education. An ASHE-ERIC Reader. San Francisco, CA: Jossey-Bass.

Talburt, S., \& Boyles, D. (2005). Reconsidering learning communities: Expanding the discourse by challenging the discourse. The Journal of General Education, 54(3), 209-236.

Terenzini, P. T. (1987). Studying student attrition and retention. In J. A. Muffo \& G. W. McLaughlin (Eds.), A primer on institutional research (pp. 20-35). Tallahassee: Association for Institutional Research

Terrion, J. L., \& Daoust, J-L. (2012). Assessing the impact of supplemental instruction on the retention of undergraduate students after controlling for motivation. Journal of College Student Retention, 13(3), 311-327.

Thelin, J. R. (2011). A history of American higher education. Baltimore, MD: The Johns Hopkins University Press.

Tinto, V. (1975). Dropout from higher education: A theoretical synthesis of recent research. Review of Educational Research, 45(1), 89-125.

Tinto, V (1993). Leaving college: Rethinking the causes and cures of student attrition, 2nd ed. Chicago, IL: University of Chicago Press.

Tinto, V. (2007). Research and practice of student retention: What next? Journal of College Student Retention, 8(1), 1 - 19.

Tobolowsky, B. F., \& Associates (2008). 2006 National Survey of First-Year Seminars: Continuing innovations in the collegiate curriculum (Monograph No. 51). 
Columbia, SC: University of South Carolina, National Resource Center for The First-Year Experience and Students in TransitionUniversity of South Carolina. History of the First University Seminar \& the University 101 Program. Retrieved from: http://www.sc.edu/univ101/aboutus/history.html

Valentine, J. C., Cooper, H. (2008). Methodological quality of intervention effectiveness research: The study design implementation assessment device (Study DIAD). Psychological Methods, 13(2), $130-149$.

Valentine, J. C., DuBois, D. L., Cooper, H. (2004). The relation between self-beliefs and academic achievement: A meta-analytic review. Educational Psychologist, $39(2), 111-133$.

Wells, R. (2009). Social and cultural capital, race and ethnicity, and college student retention. Journal of College Student Retention: Research Theory \& Practice, 10(2), 103-128.

Willcoxson, L., Cotter, J., \& Joy, S. (2011). Beyond the first-year experience: the impact on attrition of student experiences throughout undergraduate degree studies in six diverse universities. Studies in Higher Education, 36(3), 331-352.

Williford, M. A., Chapman, L. C., Kahrig, T. (2001). The university experience course: A longitudinal study of student performance, retention, and graduation. Journal of College Student Retention, 2(4), 327-340.

Wyckoff, S. (1998). Retention theories in higher education: Implications for institutional practice. Recruitment \& Retention in Higher Education, 12 (2), 2-7 
Zaback, K., Carlson, A., Crellin, M. (2012). The economic benefits of postsecondary degrees: A state and national level analysis. Boulder, CO: State Higher Education Executive Officers. 
Figure 1

Trim \& Fill Analysis - First Term GPA

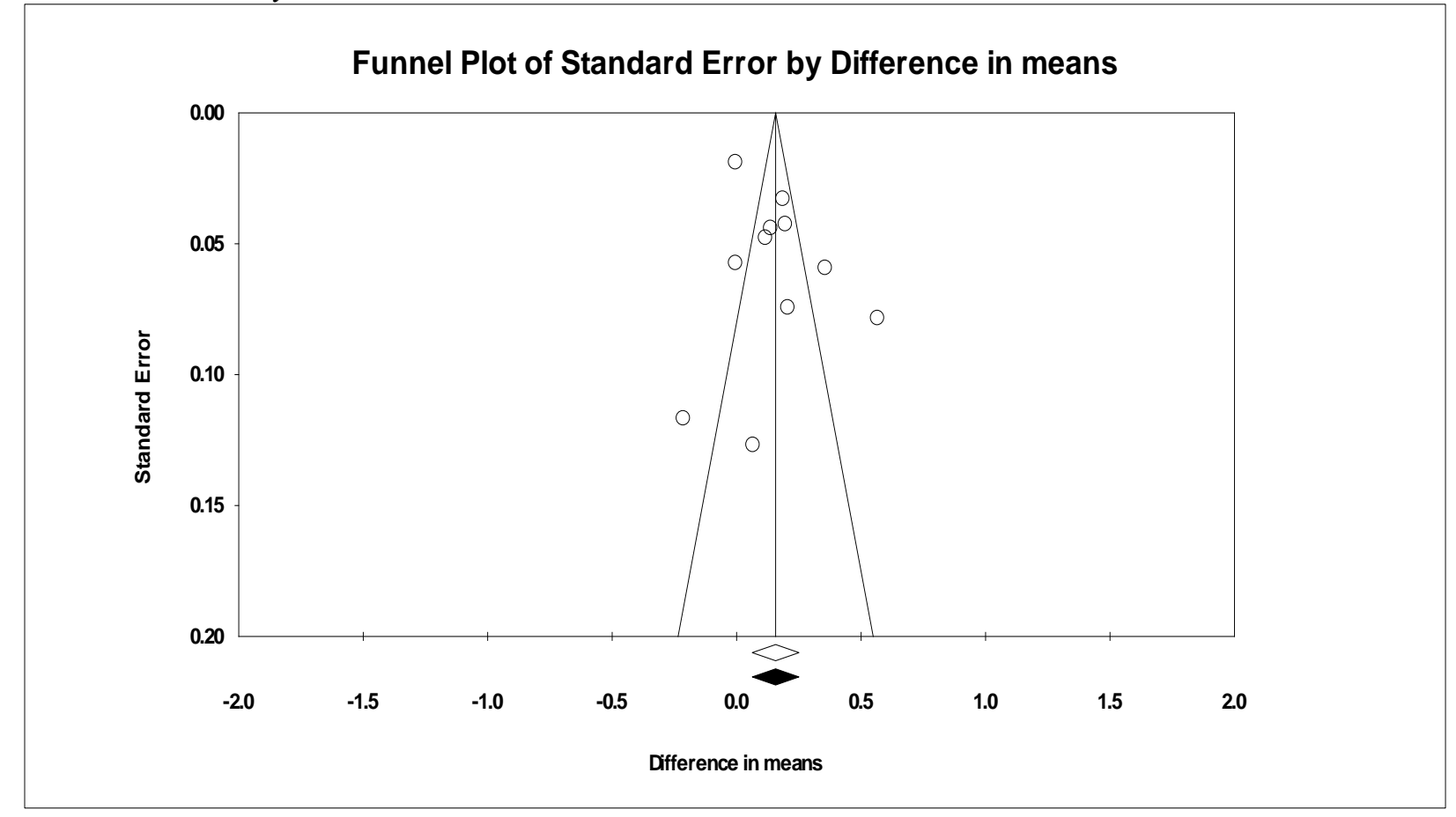

Duval and Tweedie's trim and fill

\begin{tabular}{lcccccccc} 
& \multicolumn{3}{c}{ Fixed Effects } & \multicolumn{3}{c}{ Random Effects } & Q Value \\
$\begin{array}{l}\text { Studies } \\
\text { Trimmed }\end{array}$ & $\begin{array}{c}\text { Point } \\
\text { Estimate }\end{array}$ & $\begin{array}{c}\text { Lower } \\
\text { Limit }\end{array}$ & $\begin{array}{c}\text { Upper } \\
\text { Limit }\end{array}$ & $\begin{array}{c}\text { Point } \\
\text { Estimate }\end{array}$ & $\begin{array}{c}\text { Lower } \\
\text { Limit }\end{array}$ & $\begin{array}{c}\text { Upper } \\
\text { Limit }\end{array}$ & \\
& & & & & & & & \\
& & & & & & & & \\
& 0.10168 & 0.07665 & 0.12670 & 0.15659 & 0.06270 & 0.25049 & 107.49040 \\
0 & 0.10168 & 0.07665 & 0.12670 & 0.15659 & 0.06270 & 0.25049 & 107.49040
\end{tabular}


Figure 2

Trim and Fill Analysis - First Year GPA

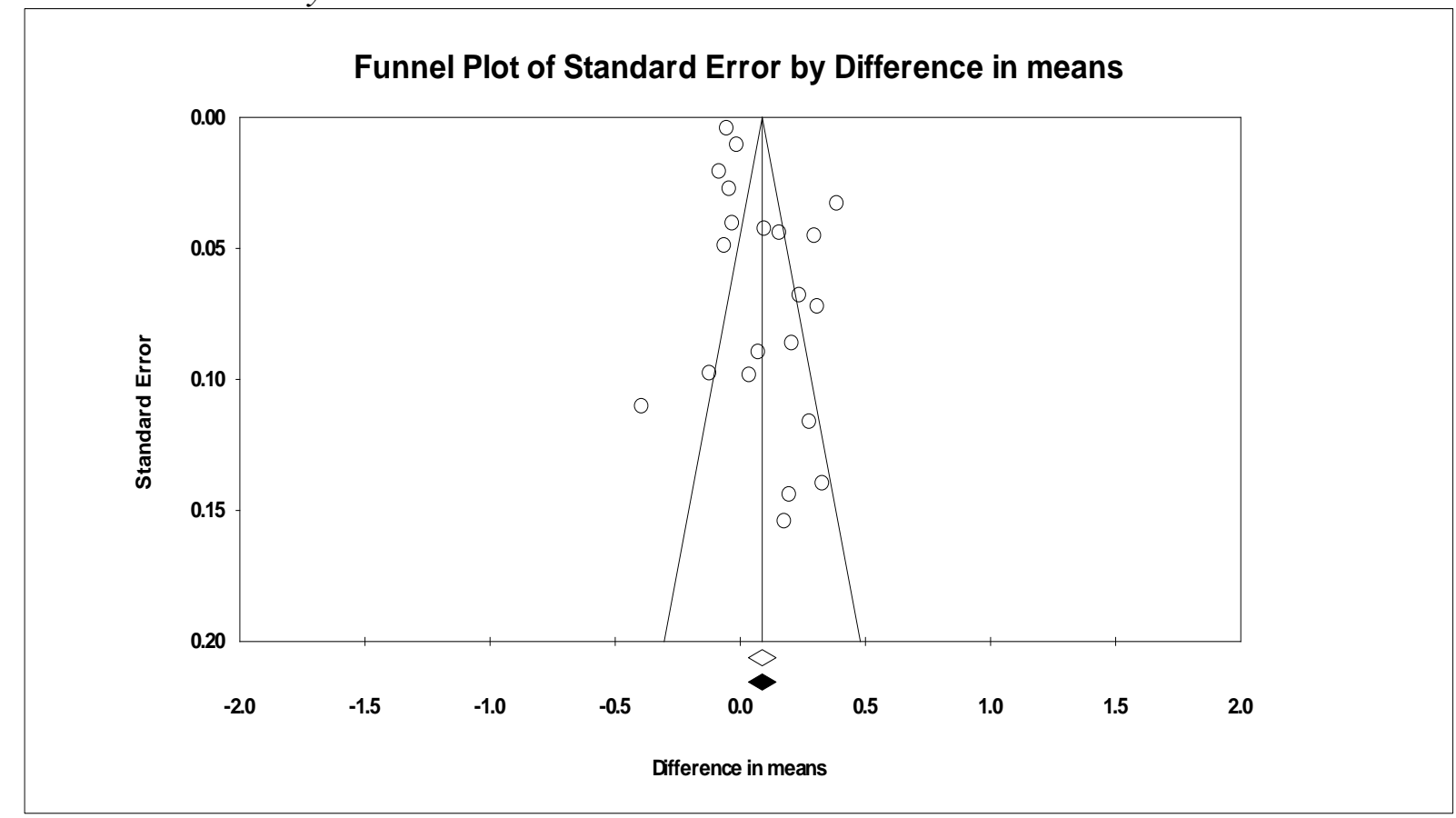

Duval and Tweedie's trim and fill

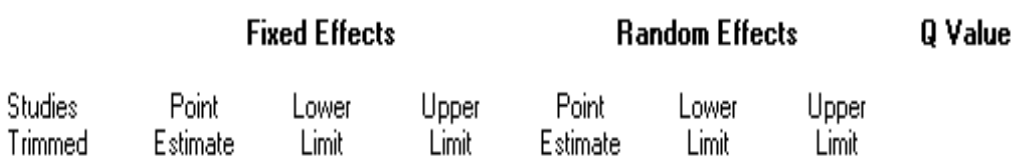

Observed values

$\begin{array}{llllllll} & -0.03050 & -0.03818 & -0.02282 & 0.08762 & 0.03250 & 0.14273 & 345.44339 \\ 0 & -0.03050 & -0.03818 & -0.02282 & 0.08762 & 0.03250 & 0.14273 & 345.44339\end{array}$


Figure 3

Trim and Fill Analysis - First-to-Second Year Retention

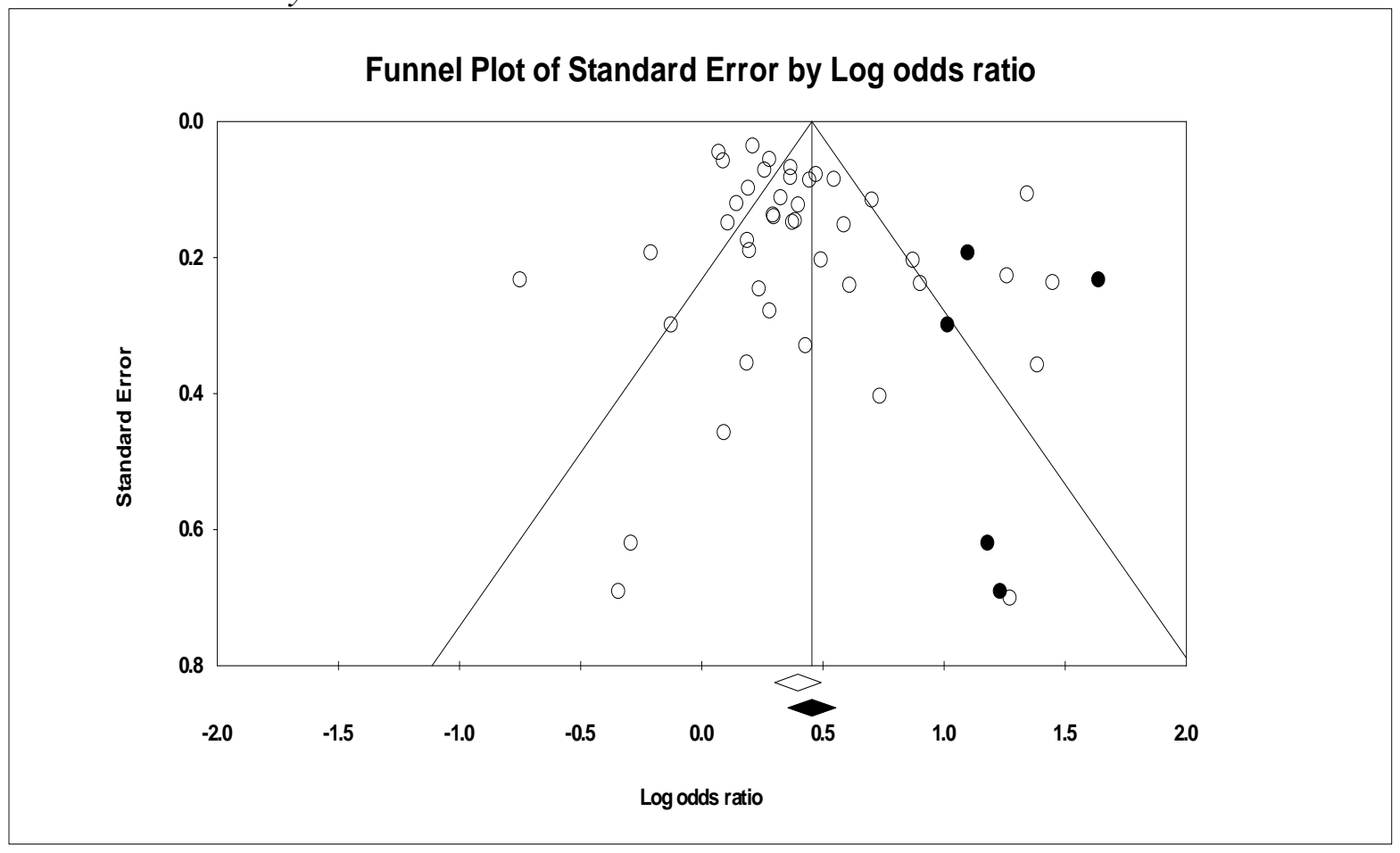

Duval and Tweedie's trim and fill

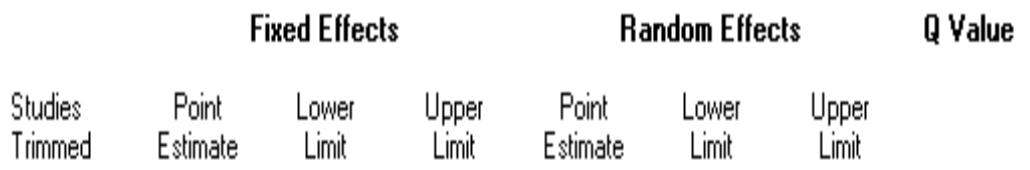

Observed values

$\begin{array}{llllllll} & 0.30818 & 0.27618 & 0.34018 & 0.39678 & 0.30104 & 0.49251 & 275.04543 \\ 5 & 0.32320 & 0.29146 & 0.35495 & 0.45434 & 0.35507 & 0.55361 & 332.54487\end{array}$




\section{APPENDICES}

\section{Appendix A - Screening Coding Guide}

\begin{tabular}{|c|c|}
\hline Study Inclusion Criteria & \\
\hline $\begin{array}{l}\text { 1. Is this study examining an extended orientation first-year } \\
\text { seminar? }\end{array}$ & $\begin{array}{l}\text { 0. No } \\
\text { 1. Yes } \\
\text { 2. Can't tell } \\
\text { If no then stop }\end{array}$ \\
\hline $\begin{array}{l}\text { 2. Is this study comparing students who were enrolled in a FYS } \\
\text { versus students who were not enrolled in an FYS? }\end{array}$ & $\begin{array}{l}\text { 0. No } \\
\text { 1. Yes } \\
\text { 2. Can't tell } \\
\text { If no then stop }\end{array}$ \\
\hline 3. Was enrollment in the seminar voluntary? & $\begin{array}{l}\text { 0. No } \\
\text { 1. Yes } \\
\text { 2. Can't tell } \\
\text { If no then stop }\end{array}$ \\
\hline 4. Was this a quantitative study? & $\begin{array}{l}\text { 0. No } \\
\text { 1. Yes } \\
\text { 2. Can't tell } \\
\text { If no then stop } \\
\end{array}$ \\
\hline $\begin{array}{l}\text { 5. Did the study report students' first year GPA and/or first-to- } \\
\text { second year retention? }\end{array}$ & $\begin{array}{l}\text { 0. No } \\
\text { 1. Yes } \\
\text { 2. Can't tell } \\
\text { If no then stop }\end{array}$ \\
\hline 6. Did this study take place at a 4 -year university in the US? & $\begin{array}{c}0 . \text { No } \\
\text { 1. Yes } \\
\text { If no then stop }\end{array}$ \\
\hline
\end{tabular}


Appendix B - Full Coding Guide

\begin{tabular}{|c|c|}
\hline Study Background/Characteristics & \\
\hline 1. Report ID & \\
\hline 2. First Author (Last name) & \\
\hline 3. First page number & \\
\hline 4. Year of Publication & \\
\hline 5. Publication Status & $\begin{array}{l}\text { 0. Unpublished } \\
\text { 1. Journal } \\
\text { 2. Book/Book Chapter } \\
\text { 3. Agency Report } \\
\text { 4. Dissertation } \\
\text { 4. Other }\end{array}$ \\
\hline
\end{tabular}




\begin{tabular}{|c|c|}
\hline FYS Experiences & \\
\hline 6. Intended length of FYS program & $\begin{array}{l}\text { Less than } 1 \text { Semester } \\
1 \text { Semester } \\
1 \text { Y Year } \\
>1 \text { Year }\end{array}$ \\
\hline $\begin{array}{l}\text { 7. Under what general umbrella does the } \\
\text { FYS fall? } \\
\text { Note: Use the authors' designation unless } \\
\text { it seems problematic or unclear. }\end{array}$ & $\begin{array}{l}\text { 1. Extended Orientation/Transition Themed } \\
\text { 2. Academic Themed } \\
\text { 3. Discipline Specific } \\
\text { 4. Remedial Education } \\
\text { 5. Academic Probation Seminar } \\
\text { 6. Other } \\
\text { 7. Can't tell }\end{array}$ \\
\hline 8. Topics Covered in Seminar & $\begin{array}{l}\text { 1. College transition } \\
\text { 2. Study strategies } \\
\text { 3. Academic remediation skills } \\
\text { 4. Advising/career \& major } \\
\text { exploration } \\
\text { 5. Discipline/Major Content } \\
\text { 6. Multicultural Issues } \\
\text { 7. Interdisciplinary } \\
\text { 8. Academically Integrated } \\
\text { 9. Can't tell }\end{array}$ \\
\hline
\end{tabular}




\begin{tabular}{|l|l|}
\hline & \multicolumn{1}{|c|}{10. Other } \\
\hline $\begin{array}{l}\text { 9. Was Participation in the FYS } \\
\text { voluntary? }\end{array}$ & $\begin{array}{l}\text { 0. No } \\
1 . \text { Yes }\end{array}$ \\
\hline 10. Was the FYS credit bearing? & $\begin{array}{l}\text { 0. No } \\
1 . \text { Yes }\end{array}$ \\
\hline $\begin{array}{l}\text { 13a. If yes, what was the co-curricular } \\
\text { portion? }\end{array}$ & 0. No \\
\hline 13. Was there a co-curricular component? & 0. No \\
& 1. Yes \\
\hline 12. Was the FYS Pass/Fail? & 0. No \\
\hline
\end{tabular}




\begin{tabular}{|c|c|}
\hline 14. Was the Instructor full time faculty? & 1. Yes \\
\hline 15. Was the course team taught? & $\begin{array}{l}\text { 0. No } \\
\text { 1. Yes } \\
\text { 2. Can't Tell }\end{array}$ \\
\hline $\begin{array}{l}\text { 15a. If yes, who were the co-teachers } \\
\text { (what were their roles on campus)? }\end{array}$ & \\
\hline FYS Setting/Environment & \\
\hline $\begin{array}{l}\text { 18. Carnegie Classification of the } \\
\text { university of study. } \\
\text { Note: These are Carnegies' Basic } \\
\text { Classification categories as of March, } \\
2013\end{array}$ & $\begin{array}{l}\text { 1. Associate's College } \\
\text { 2. Doctorate-Granting University } \\
\text { 3. Master's College/University } \\
\text { 4. Baccalaureate College } \\
\text { 5. Special Focus Institution } \\
\text { 6. Tribal College }\end{array}$ \\
\hline $\begin{array}{l}\text { 19. What region of the United States is } \\
\text { the institution located? }\end{array}$ & $\begin{array}{l}\text { 1. Northeast } \\
\text { 2. Southeast } \\
\text { 3. South } \\
\text { 4. Midwest } \\
\text { 5. Upper Midwest } \\
\text { 6. West } \\
\text { 7. Northwest }\end{array}$ \\
\hline
\end{tabular}




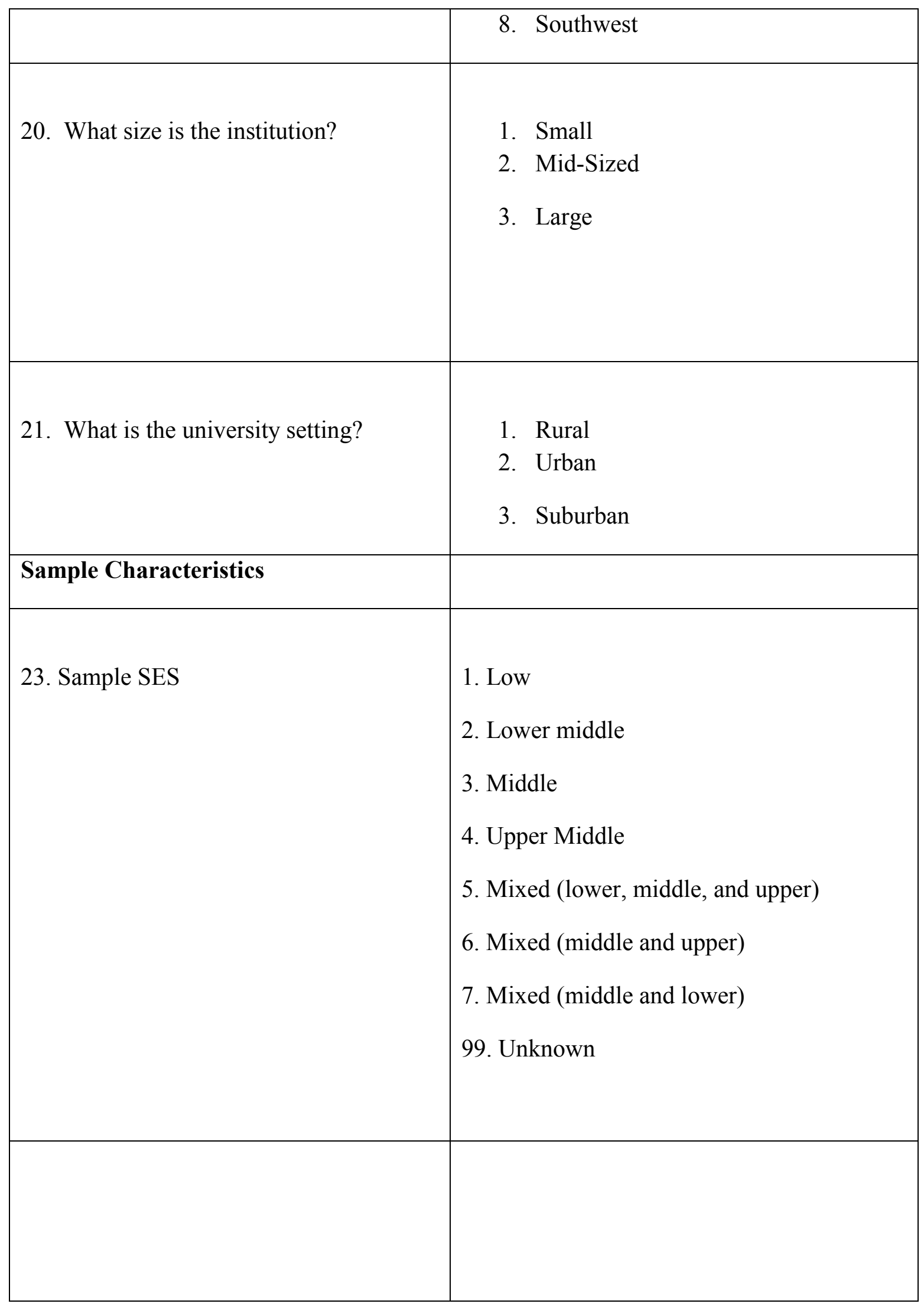




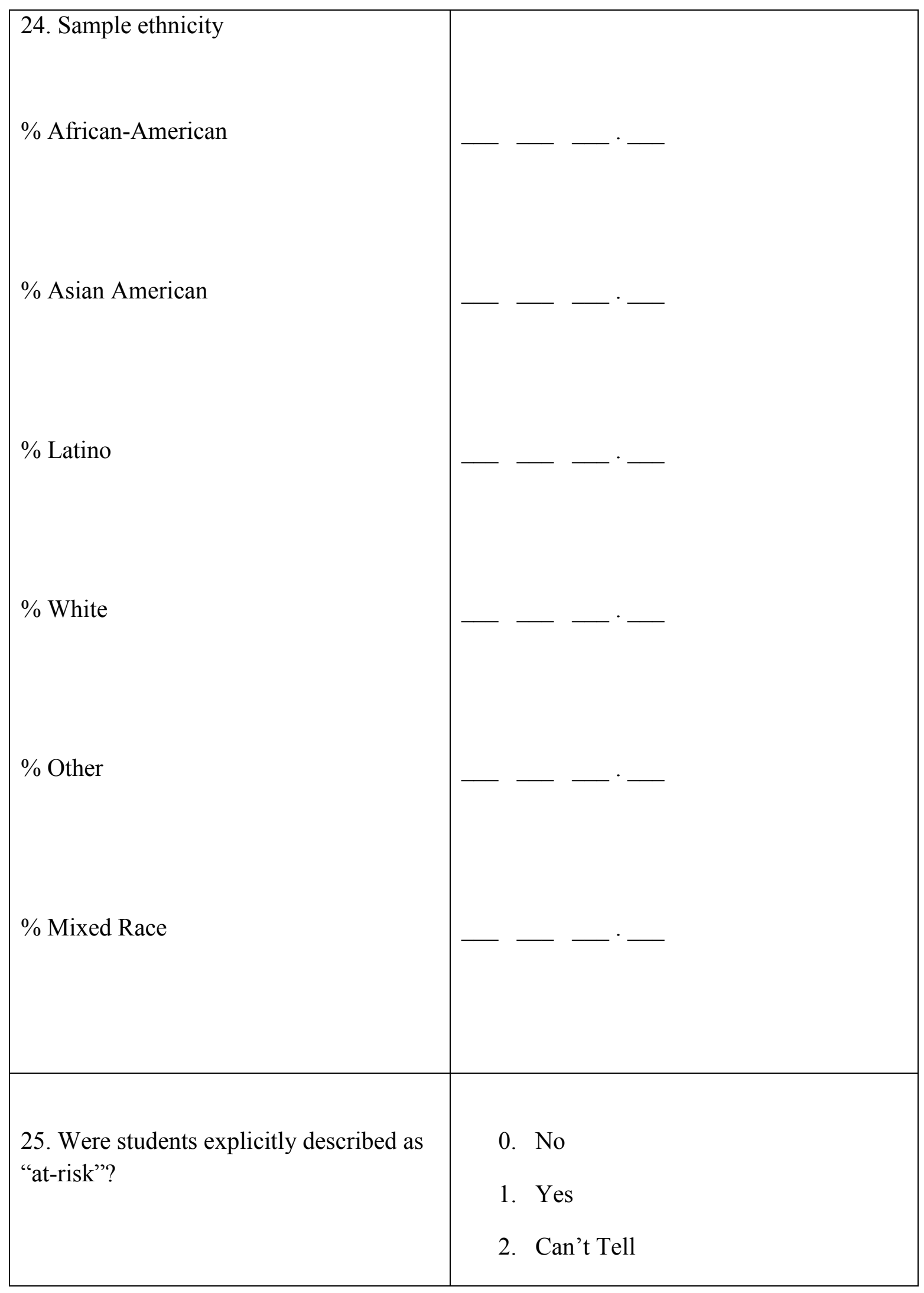




\begin{tabular}{|c|c|}
\hline 26. Gender Demographics & \\
\hline 26a. \% Male & $-\ldots \ldots$ - \\
\hline 26b. \% Female & 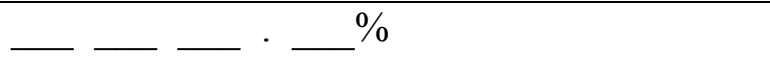 \\
\hline 27. Year of Study & $\begin{array}{l}\text { 1. Freshman } \\
\text { 2. Sophomore } \\
\text { 3. Junior } \\
\text { 4. Senior }\end{array}$ \\
\hline Research Design & \\
\hline 28. Research design & $\begin{array}{l}\text { 1. Randomized assignment } \\
\text { 2. Non Random Assignment } \\
\text { 3. Quasi-Experimental } \\
\text { 4. Other }\end{array}$ \\
\hline $\begin{array}{l}\text { 29. Was matching used to place students } \\
\text { in FYS? }\end{array}$ & $\begin{array}{l}\text { 0. No, these were not used } \\
\text { 1. Yes, matching }\end{array}$ \\
\hline $\begin{array}{l}\text { 29a. If matching was used, what } \\
\text { variable(s) were used to equate the }\end{array}$ & 0. n/a, no matching or statistical control \\
\hline
\end{tabular}




\begin{tabular}{|c|c|}
\hline groups? (Circle all that apply.) & $\begin{array}{l}\text { was used } \\
\text { 1. pretest of commirment construct } \\
\text { 2. prior academic achievement } \\
\text { 3. SES } \\
\text { 4. Student Sex } \\
\text { 5. Multiple variables } \\
\text { 6. Propensity score matching } \\
\text { 7. Other } \\
\text { 9. Can't tell }\end{array}$ \\
\hline $\begin{array}{l}\text { 31. Total sample size at the beginning of } \\
\text { the study }\end{array}$ & \\
\hline $\begin{array}{l}\text { 31a. What was the FYS sample size at the } \\
\text { beginning of the study? }\end{array}$ & ---- \\
\hline $\begin{array}{l}\text { 31b. What was the comparison group } \\
\text { sample size at the beginning of the study? }\end{array}$ & ---- \\
\hline
\end{tabular}




\begin{tabular}{|c|c|}
\hline $\begin{array}{l}\text { 32. Did the study include some measure } \\
\text { of prior academic ability (HS GPA, ACT, } \\
\text { SAT, etc.)? }\end{array}$ & $\begin{array}{l}0 . \text { No } \\
\text { 1. Yes }\end{array}$ \\
\hline 32a. If yes, list page number: & 2. p. - - - \\
\hline $\begin{array}{l}\text { 33. Did the study give an indication about } \\
\text { the baseline comparability of groups in } \\
\text { terms of other (non-achievement) } \\
\text { characteristics? }\end{array}$ & $\begin{array}{l}\text { 0. No } \\
\text { 1. Yes }\end{array}$ \\
\hline 33a. If yes, list page number: & 2. p. \\
\hline $\begin{array}{l}\text { Measurement Characteristics } \\
\text { (Note: Complete for every outcome } \\
\text { measured) }\end{array}$ & \\
\hline $\begin{array}{l}\text { 34. Is retention/persistence to the second } \\
\text { semester or second year a dependent } \\
\text { variable? }\end{array}$ & $\begin{array}{ll}0 . & \text { No } \\
\text { 1. } & \text { Yes }\end{array}$ \\
\hline 35. Is academic achievement as measured & 0 . No \\
\hline
\end{tabular}




\begin{tabular}{|c|c|}
\hline $\begin{array}{l}\text { by first semester or first year GPA } \\
\text { measured as a dependent variable? }\end{array}$ & 1. Yes \\
\hline $\begin{array}{l}\text { 36. Name other DV's measured } \\
\text { Note: When there are multiple DVs, be as } \\
\text { clear as possible in your labeling. Use the } \\
\text { rest of the cell to make notes that might } \\
\text { help your memory. }\end{array}$ & Name: \\
\hline 37. Source/Informant for Data & $\begin{array}{l}\text { 1. Student self-report } \\
\text { 2. Admission/HS information } \\
\text { 3. Registrar/institutional research office } \\
\text { 4. Other } \\
\text { 9. Can't tell }\end{array}$ \\
\hline $\begin{array}{l}\text { 46. At how many points in time was the } \\
\text { DV measured? (Not including pretests) }\end{array}$ & - \\
\hline $\begin{array}{l}\text { 47. Were the DVs measured at the end of } \\
\text { the first semester? }\end{array}$ & $\begin{array}{ll}0 . & \text { No } \\
\text { 1. } & \text { Yes }\end{array}$ \\
\hline
\end{tabular}




\title{
Appendix C - Study Request Protocol
}

Dear Colleagues:

I am reaching out for help in finding previous research on first year seminars. I'm currently conducting a meta-analysis which will examine the effectiveness of extended orientation/transition first year seminars. Specifically I am exploring the impact of these courses on first term GPA, first year GPA, and/or on first-to-second-year retention of first time undergraduates at 4-year universities in the US. I am reaching out to our FYE community to ask whether any of you have conducted, are conducting, or are aware of studies which have investigated extended orientation first-year seminars' impact on these outcomes but that have not (for whatever reason) been published. If you know of any such studies and are willing to share them with me or direct me toward the study author(s) I would be extremely grateful. If anyone is willing do so please contact me directly via email.

Thank you all for any help you might provide and for the work you do in advancing first year success!

\author{
Matthew Berry \\ Doctoral Candidate/Graduate Research Assistant \\ College of Education \& Human Development \\ University of Louisville
}


Appendix D - Group Comparability

\begin{tabular}{|c|c|c|c|c|c|}
\hline First Author & $\%$ Minority & HS GPA & SAT/ACT & $\begin{array}{l}\text { Low } \\
\text { SES }\end{array}$ & $\begin{array}{c}\text { First } \\
\text { Generation }\end{array}$ \\
\hline Beal & - & - & - & - & - \\
\hline Behrman & - & - & - & - & - \\
\hline Bitz & - & - & & - & - \\
\hline Blackett & 58 & - & - & - & - \\
\hline Brunelle-Joiner & 18 & .14 & .01 & - & - \\
\hline Burgette & 35 & -.02 & -.02 & - & - \\
\hline Cambridge-Williams & 38 & .05 & .14 & - & .75 \\
\hline Carstens & - & - & - & - & - \\
\hline Cavote & - & .24 & .23 & - & 1.26 \\
\hline Chartriand & - & - & - & - & - \\
\hline Clark & 29 & -.70 & -.84 & - & - \\
\hline Craig & 27 & - & -.28 & - & - \\
\hline Davis & - & -.08 & -.50 & - & - \\
\hline Davis-Underwood & - & - & - & - & - \\
\hline Douthett & 6 & - & -.42 & - & - \\
\hline Fidler & - & - & - & - & - \\
\hline Fry & 21 & -.16 & $\begin{array}{l}.23 \text { (SAT) } \\
-.20(\mathrm{ACT})\end{array}$ & - & - \\
\hline Frysinger & - & - & - & - & - \\
\hline Green & 11 & - & - & - & - \\
\hline Helbig & 8 & - & - & - & - \\
\hline Hollins & 27 & - & -.17 & - & - \\
\hline House & - & - & - & - & - \\
\hline Jackson & - & - & - & - & - \\
\hline Janz & 9 & - & -.10 & - & - \\
\hline Lang & 24 & -.07 & -.03 & - & - \\
\hline Lashley & - & - & - & - & - \\
\hline McMillan-Haron & 42 & - & - & - & - \\
\hline Micceri & - & - & - & - & - \\
\hline Miller $_{a}$ & - & - & - & - & - \\
\hline Miller $_{b}$ & - & - & - & - & - \\
\hline Nottingham & - & - & -.82 & - & - \\
\hline Rogers & 31 & & & & \\
\hline Schnell & - & - & - & - & - \\
\hline Shanley & 47 & - & - & - & - \\
\hline Sidle & 48 & - & - & - & - \\
\hline Spann & 7 & - & - & - & - \\
\hline Sparks & 47 & & & & \\
\hline Starke & 29 & - & - & - & - \\
\hline Stewart & 25 & - & -.11 & - & - \\
\hline TeDuits & 70 & - & - & - & - \\
\hline
\end{tabular}




\begin{tabular}{|l|c|c|c|c|c|}
\hline Weissman & 18 & 0 & -.05 & - & .71 \\
\hline Williford & - & - & - & - & - \\
\hline Yale & - & - & - & - & - \\
\hline Yarbrogh & - & - & - & - & - \\
\hline Yu & - & - & - & - & - \\
\hline
\end{tabular}

Notes. HS GPA = high school grade point average. For HS GPA, and SAT/ACT the statistics in the cells are standardized mean differences. For Low SES and first generation status, the statistics in the cells are odds ratios. 
Appendix E - Moderator Table

\begin{tabular}{|c|c|c|c|c|c|c|c|c|c|c|}
\hline Study & $\begin{array}{c}\text { Sample > } \\
\text { Median }\end{array}$ & $\begin{array}{c}\text { Matching } \\
\text { /Control }\end{array}$ & $\begin{array}{l}\text { Multiple } \\
\text { Cohorts }\end{array}$ & $\begin{array}{c}\text { Large } \\
\text { Institution }\end{array}$ & $\begin{array}{c}\text { Doctorate- } \\
\text { Granting }\end{array}$ & Faculty & $\begin{array}{l}\text { New } \\
\text { FYS }\end{array}$ & $\begin{array}{c}\text { Co- } \\
\text { Curricular }\end{array}$ & $\begin{array}{l}>75 \% \\
\text { White }\end{array}$ & $\begin{array}{c}\text { Peer } \\
\text { Mentor }\end{array}$ \\
\hline Beal & 0 & 0 & 1 & 0 & 0 & 1 & 1 & 0 & 99 & 1 \\
\hline Behrman & 1 & 0 & 1 & 99 & 99 & 0 & 1 & 1 & 99 & 1 \\
\hline Bitz & 1 & 1 & 1 & 99 & 99 & 99 & 99 & 1 & 99 & 1 \\
\hline Blackett & 1 & 1 & 1 & 1 & 1 & 0 & 1 & 1 & 1 & 1 \\
\hline Brunelle-Joiner & 1 & 0 & 1 & 0 & 0 & 1 & 0 & 0 & 0 & 0 \\
\hline Burgette & 1 & 0 & 1 & 0 & 0 & 1 & 1 & 0 & 1 & 1 \\
\hline Cambridge-Williams & 1 & 1 & 1 & 0 & 0 & 0 & 1 & 0 & 1 & 0 \\
\hline Carstens & 1 & 0 & 0 & 1 & 1 & 0 & 1 & 0 & 99 & 1 \\
\hline Cavote & 1 & 1 & 1 & 0 & 0 & 0 & 0 & 1 & 99 & 1 \\
\hline Chartriand & 0 & 0 & 0 & 0 & 0 & 0 & 1 & 99 & 99 & 99 \\
\hline Clark & 1 & 0 & 1 & 0 & 0 & 1 & 1 & 0 & 1 & 1 \\
\hline Craig & 0 & 0 & 0 & 0 & 1 & 0 & 1 & 1 & 1 & 1 \\
\hline Davis & 1 & 0 & 0 & 0 & 1 & 0 & 1 & 1 & 99 & 1 \\
\hline Davis-Underwood & 1 & 0 & 1 & 0 & 0 & 0 & 1 & 0 & 99 & 1 \\
\hline Douthett & 0 & 0 & 0 & 0 & 0 & 1 & 1 & 1 & 0 & 1 \\
\hline Fidler & 0 & 1 & 0 & 0 & 0 & 0 & 1 & 0 & 99 & 1 \\
\hline Fry & 0 & 0 & 1 & 0 & 0 & 0 & 1 & 1 & 0 & 1 \\
\hline Frysinger & 1 & 1 & 0 & 0 & 0 & 0 & 1 & 1 & 99 & 1 \\
\hline Green & 1 & 1 & 0 & 1 & 1 & 0 & 0 & 1 & 0 & 1 \\
\hline Helbig & 0 & 0 & 0 & 0 & 1 & 0 & 1 & 0 & 0 & 1 \\
\hline Hollins & 0 & 1 & 0 & 0 & 0 & 1 & 1 & 1 & 1 & 0 \\
\hline House & 0 & 1 & 0 & 0 & 0 & 1 & 1 & 99 & 99 & 1 \\
\hline Jackson & 0 & 1 & 0 & 0 & 0 & 1 & 1 & 1 & 99 & 0 \\
\hline Janz & 0 & 0 & 1 & 0 & 1 & 0 & 1 & 1 & 0 & 1 \\
\hline Lang & 0 & 0 & 1 & 0 & 0 & 1 & 1 & 0 & 0 & 1 \\
\hline Lashley & 0 & 1 & 0 & 1 & 1 & 0 & 1 & 1 & 99 & 0 \\
\hline McMillan-Haron & 0 & 1 & 1 & 0 & 0 & 1 & 1 & 1 & 1 & 1 \\
\hline Micceri & 0 & 0 & 0 & 0 & 0 & 0 & 1 & 0 & 99 & 1 \\
\hline Miller $_{\mathrm{a}}$ & 0 & 1 & 0 & 1 & 1 & 0 & 1 & 1 & 99 & 1 \\
\hline Miller $_{b}$ & 0 & 1 & 0 & 1 & 1 & 0 & 1 & 1 & 99 & 1 \\
\hline Nottingham & 1 & 0 & 1 & 0 & 0 & 1 & 0 & 1 & 99 & 1 \\
\hline
\end{tabular}




\begin{tabular}{|c|c|c|c|c|c|c|c|c|c|c|}
\hline Rogers & 0 & 1 & 1 & 0 & 0 & 0 & 1 & 99 & 1 & 1 \\
\hline Schnell & 0 & 0 & 0 & 0 & 0 & 0 & 1 & 1 & 99 & 1 \\
\hline Shanley & 0 & 1 & 1 & 0 & 0 & 1 & 1 & 0 & 1 & 1 \\
\hline Sidle & 1 & 0 & 1 & 1 & 1 & 0 & 1 & 99 & 1 & 1 \\
\hline Spann & 1 & 1 & 1 & 0 & 1 & 1 & 1 & 0 & 0 & 1 \\
\hline Sparks & 0 & 1 & 0 & 1 & 1 & 1 & 1 & 1 & 1 & 1 \\
\hline Starke & 1 & 1 & 1 & 1 & 1 & 0 & 1 & 0 & 1 & 1 \\
\hline Stewart & 1 & 0 & 1 & 0 & 0 & 1 & 1 & 0 & 1 & 1 \\
\hline TeDuits & 0 & 1 & 1 & 0 & 0 & 0 & 1 & 99 & 1 & 0 \\
\hline Weissman & 1 & 1 & 1 & 0 & 0 & 1 & 1 & 99 & 0 & 0 \\
\hline Williford & 0 & 0 & 0 & 0 & 0 & 1 & 1 & 99 & 99 & 0 \\
\hline Yale & 1 & 1 & 1 & 1 & 1 & 0 & 1 & 0 & 99 & 1 \\
\hline Yarbrogh & 1 & 0 & 1 & 0 & 0 & 1 & 1 & 0 & 99 & 0 \\
\hline $\mathrm{Yu}$ & 1 & 0 & 1 & 99 & 99 & 0 & 0 & 99 & 99 & 1 \\
\hline
\end{tabular}

Notes. 99 indicates a missing value. The median sample size was 1,210. Studies above this value are notated as 0 , studies below this value are notate as 1 . O indicates that the study employed matching or statistical control, 1 indicates that studies did not use matching or control. O indicates that studies followed multiple cohorts, 1 indicates that it did not use multiple cohorts. Studies that took place at large institutions are denoted with a 0 , while those that did not are denoted with a 1 . Studies that took place at a doctorate-granting institution are denoted by 0 , studies that took place at a Masters or Baccalaureate granting institution are denoted by a 1 . Courses taught only by faculty are denoted by 0 , courses taught by faculty or teams of faculty and staff are denoted with a 1 . Studies investigating new courses are denoted by 0 , studies which did not investigate a new course are denoted by a 1 . Courses with cocurricular components are denoted by a 0 , those without a co-curricular component are denoted by a 1 . Samples that are over $75 \%$ White are denoted by a 0 , those that are less than $75 \%$ White are denoted by 1 . Courses which used a peer mentor are denoted by a 0 , those courses that did not are denoted by a 1 . 
Appendix F - Studies Included in Meta-Analytic Samples

Beal, K. (1998). Wright State University. In B. O. Barefoot, C. L. Wamock, S. E.

Richardson, \& M. R. Roberts (Series Eds.), Exploring the evidence: Reporting outcomes

of first-year seminars, Volume II (pp. 107-108). Columbia, SC: University of South

Carolina, National Resource Center for the First-Year Experience and Students in

Transition.

Behrman, J. A. (1984). The effects of a structured learning-skills intervention on long-term academic performance. Journal of College Student Personnel,25(4), 326 - 331.

Bitz, K. (2011). Implementation of a first-year seminar: Retention and student views of advising and engagement at a small midwestern university. (Order No. 3515489, The University of North Dakota). ProQuest Dissertations and Theses, , 111. Retrieved from http://search.proquest.com/docview/1024342272?accountid=14665. (1024342272).

Blackett, K. B. (2008). The effects of a first-year success course on student retention and academic achievement at national american university. (Order No. 3318814, University of South Dakota). ProQuest Dissertations and Theses, , 126-n/a. Retrieved from http://search.proquest.com/docview/304488623?accountid=14665. (3044886623).

Brunelle-Joiner, K. (1999). Effects of an extended orientation program on personal resiliency and adjustment to college as it relates to academic performance and retention. (Order No. 9919688, The Florida State University). ProQuest Dissertations and Theses, , 169-169 p. Retrieved from http://search.proquest.com/docview/304520545?accountid=14665. (304520545). 
Burgette, J. E., Magun-Jackson, S. (2009). Freshman orientation, persistence, and achievement: A longitudinal analysis. Journal of College Student Retention, 10(3), 235263.

Cambridge-Williams, T., Winsler, A., Kitsantas, A., \& Bernard, E. (2013). University 100 orientation courses and living-learning communities boost academic retention and graduation via enhanced self-efficacy and self-regulated learning. Journal of College Student Retention, 15(2), $243-266$.

Carstens, J. B. (2000). Effects of a freshman orientation course on academic outcomes, quality of effort and estimated intellectual gain. (Order No. 9975638, The University of Iowa). ProQuest Dissertations and Theses, , 159-159 p. Retrieved from http://search.proquest.com/docview/304603094?accountid=14665. (304603094).

Cavote, S., Kopera-Frye, K. (2007). Non-traditional student persistence and first year experience courses. Journal of College Student Retention, 8(4), 477 - 489.

Chatriand, C. M. (2012). The effect of selected campus connection programs on GPA and retention. (Order No. 3511370, Iowa State University). ProQuest Dissertations and Theses, , 171. Retrieved from http://search.proquest.com/docview/1022645154?accountid=14665. (1022645154).

Clark, M. H., Cundiff, N. L. (2011). Assessing the effectiveness of a college freshman seminar using propensity score adjustments. Research in Higher Education, 52, 616 639.

Craig, K. L. (1994). Student retention and academic performance: Relationship to a freshman seminar/student success course. (Order No. 9521941, The University of Southern 
Mississippi). ProQuest Dissertations and Theses, , 108-108 p. Retrieved from http://search.proquest.com/docview/304130096?accountid=14665. (304130096).

Davis, B. O. J. (1992). Freshman seminar: A broad spectrum of effectiveness. Journal of the Freshman Year Experience, 4(1), 79 - 94.

Davis-Underwood, M., \& Jo, A. L. (January 01, 1994). An Evaluation of The University of North Carolina at Charlotte Freshman Seminar. Journal of College Student Development, $35,6,491$.

Douthett, T. A. (1998). Policy analysis of bowling green state university's freshman seminar course. (Order No. 9913577, Bowling Green State University). ProQuest Dissertations and Theses, , 115-115 p. Retrieved from http://search.proquest.com/docview/304416949?accountid=14665. (304416949).

Fidler, P. P., Moore, P. S. (1996). A comparison of effects of campus residence and freshman seminar attendance on freshman dropout rates. Journal of the Freshman Year Epxerience, 8(2), $7-16$.

Fry, M. K. (2006). The relationship of admission type and freshman seminar participation to retention and academic success. (Order No. 3241822, Northern Arizona University). ProQuest Dissertations and Theses, , 264-264 p. Retrieved from http://search.proquest.com/docview/304957471?accountid=14665. (304957471).

Frysinger, V. F. (1998). Improving undergraduate retention at texas A\&M university: Impact of participation in selected study skills courses. (Order No. 9830905, Texas A\&M University). ProQuest Dissertations and Theses, , 211-211 p. Retrieved from http://search.proquest.com/docview/304481675?accountid=14665. (304481675). 
Green, C. C. (2010). The effectiveness of a first-year learning strategies seminar. (Order No. 3420567, Wilmington University (Delaware)). ProQuest Dissertations and Theses, , 114. Retrieved from http://search.proquest.com/docview/749389526?accountid=14665. (749389526).

Helbig, T. L. (2004). Beating the odds: A survival analysis of the effects of freshman seminar participation on university student persistence, controlling for academic achievement, financial assistance and social integration factors. (Order No. 3158248, University of Kentucky). ProQuest Dissertations and Theses, , 103-103 p. Retrieved from http://search.proquest.com/docview/305172735?accountid=14665. (305172735).

Hollins, Thomas Neal,„Jr. (2004). Participation in an extended orientation course and its relationship with student involvement, student satisfaction, academic performance, and student retention. (Order No. 3137438, The Florida State University). ProQuest Dissertations and Theses, , 187-187 p. Retrieved from http://search.proquest.com/docview/305184164?accountid=14665. (305184164).

House, D. (1998). Dalton College. In B. O. Barefoot, C.L. Wamock, S. E. Richardson, \& M. R. Roberts (Eds.), Exploring the evidence: Reporting outcomes of first-year seminars. Volume II (pp. 87-88). Columbia, SC: University of South Carolina, National Resource Center for the First-Year Experience and Students in Transition.

Jackson. B. (2005). Indiana University-Purdue University Indianapolis. In B. F. Tobolowsky, B. E. Cox. \& M. T. Wagner (Eds.), Exploring the evidence: Reporting research on firstyear seminars, Volume ///(M onograph No. 42) (pp.61-65). Columbia. SC: University of South Carolina, National Resource Center for the First-Year Experience and Students in Transition. 
Janz, J. C. (2004). The retention impact of the freshman seminar on students with varying pre-college academic performance. (Order No. 3141095, Marquette University). ProQuest Dissertations and Theses, , 141-141 p. Retrieved from http://search.proquest.com/docview/305176036? accountid=14665. (305176036).

Lang, D. J. (2006). The impact of a first-year experience course on the academic performance, persistence, and graduation rates of first-semester college students. (Order No. 3203947, State University of New York at Buffalo). ProQuest Dissertations and Theses, , 136-136 p. Retrieved from http://search.proquest.com/docview/304938412?accountid=14665. (304938412).

Lashley, B. (2005). Eastern Connecticut State University. In B. F. Tobolowsky, B. E. Cox, \& M. T. Wagner (Eds.), Exploring the evidence: Reporting research on first-year seminars, Volume ///(M onograph No. 42) (pp.43-46). Columbia, SC: University of South Carolina, National Resource Center for the First-Year Experience and Students in Transition.

McMillan-Haron, V. (2003). The impact of freshman success courses on freshman-tosophomore persistence and academic achievement at a WICHE urban university and college. (Order No. 3091806, University of Nevada, Las Vegas). ProQuest Dissertations and Theses, , 197-197 p. Retrieved from http://search.proquest.com/docview/305270749?accountid=14665. (305270749).

Micceri, T., Wajeeh, E. (1999). Evidence supporting a university experiencecourse's efficacy at a metropolitan university, and associated effective processes. Paper Presented at the AIR Forum, May 30-June 3, 1999, Seattle, Washington. 
Miller, J. W., Janz, J. C., Chen, C. (2007). The retention impact of a first-year seminar on students with varying pre-college academic performance. Journal of the First Year Experience \& Students in Transition, 19(1), $47-62$.

Nottingham, J. E. (1989). A study of student persistence as an outcome of participation in an extended orientation course. (Order No. 9010692, The University of Connecticut). ProQuest Dissertations and Theses, , 75-75 p. Retrieved from http://search.proquest.com/docview/303699891?accountid=14665. (303699891).

Rogers, K. L.. Eglsaer, R. F, Muchsam, M. J.. Caillouet. B., \& Kan, L. (2008). Sam Houston State University. In A. M. Griffin \& J. Romm (Eds.), Exploring the evidence, vol. IV: Reporting research on first-year seminars (pp. 65-68). Columbia, SC: University of South Carolina. National Resource Center for the First-Year Experience and Students in Transition. Retrieved from http://www.sc.edu/fye/resources/fyr/pdf/MExpEvid_IV.pdf

Schnell, C. A. J. (2000). First-year seminar effectiveness: Success, retention, and subsequent graduation of college freshmen. (Order No. 9961010, University of Minnesota). ProQuest Dissertations and Theses, , 103-103 p. Retrieved from http://search.proquest.com/docview/304610421 ?accountid=14665. (304610421).

Shanley, M. G., Witten, C. G. (1990). University 101 freshman seminar course: A longitudinal study of persistence, retention, and graduation rates. NASPA Journal, 27(4), $344-352$.

Sidle, M. W., McReynolds, J. (2009). The freshman year experience: Student retention and student success. NASPA Journal, 46(3), $434-446$.

Spann, N. G. (1991). An evaluation of the freshman seminar at appalachian state university. (Order No. 9204462, The University of North Carolina at Greensboro). ProQuest 
Dissertations and Theses, , 180-180 p. Retrieved from

http://search.proquest.com/docview/303958156?accountid=14665. (303958156).

Sparks, J. (2005). California State University. San Marcos. In B. F. Tobolowsky, B. E. Cox, \& M. T. Wagner (Eds.), Exploring the evidence: Reporting research on first-year seminars. Volume III (Monograph No. 42) (pp. 33-35). Columbia, SC: University o f South Carolina. National Resource Center for the First-Year Experience and Students in Transition.

Starke, M. C., Harth, M., \& Sirianni, F. (2001). Retention, bonding, and academic achievement: Success of a first-year seminar. Journal of the First Year Experience, $13(2), 7-35$.

Stewart,Billy Wayne,,Jr. (1997). The effects of a freshman seminar course on student retention, academic success, and academic performance. (Order No. 9801970, Mississippi State University). ProQuest Dissertations and Theses, , 159-159 p. Retrieved from http://search.proquest.com/docview/304371409?accountid=14665. (304371409).

teDuits, D. J. (2007). The effects of a first-year academic support program on first time in college freshmen. (Order No. 3289810, University of Houston). ProQuest Dissertations and Theses, , 93. Retrieved from http://search.proquest.com/docview/304851301?accountid=14665. (304851301).

Weissman, J., Magill, B. A. (2008). Developing a student typology to examine the effectiveness of first-year seminars. Journal of the First Year Experience \& Students in Transition, 20(2), $66-90$. 
Williford, M. A., Chapman, L. C., \& Kahrig, T. (2001). The university experience course: A longitudinal study of student performance, retention, and graduation. Journal of College Student Retention, 2(4), 327 - 340.

Yale, A. A. (1999). The impact of a one-credit freshman seminar on student retention, academic progress, and academic and social integration, while controlling for the volunteer effect. (Order No. 9957798, University of Pittsburgh). ProQuest Dissertations and Theses, , 198-198 p. Retrieved from http://search.proquest.com/docview/304520864?accountid=14665. (304520864).

Yarbrough, E. B. (1993). The effects of an extended orientation program on student out-ofclassroom involvement as it relates to academic performance and retention. (Order No. 9413305, The Florida State University). ProQuest Dissertations and Theses, , 198-198 p. Retrieved from http://search.proquest.com/docview/304051885?accountid=14665. (304051885).

Yu, W. Y. (2012). Improving college freshman retention. (Order No. 3571096, Southern Connecticut State University). ProQuest Dissertations and Theses, , 236. Retrieved from http://search.proquest.com/docview/1439144714?accountid=14665. (1439144714). 


\title{
CURRICULUM VITAE
}

\author{
Matthew S. Berry
}

2216 Lowell Avenue Louisville, KY 40205

614-595-9984 | matthew.berry@louisville.edu

\section{EDUCATION}

UNIVERSITY OF LOUISVILLE - LOUISVILLE, KY

$\mathrm{Ph}$.D. Educational Leadership \& Organizational Development

Concentration: Post-Secondary Administration

Dissertation: The effectiveness of extended orientation first year seminars: A systematic review and meta-analysis.

Chair:Dr. Jeffrey Valentine (Proposal accepted 1/14/2014, Anticipated final defense $6 / 2014)$

BENEDICTINE UNIVERSITY - LISLE, IL

Master of Science Management \& Organizational Behavior (2011)

Concentrations: Organizational Behavior \& Organizational Development

WITTENBERG UNIVERSITY - SPRINGFIELD, OH

Bachelor of Arts Communication (2006)

\section{ACADEMIC RESEARCH}

Hillman, N., Weichman, T., Gross, J.P.K., Berry, M. (2013). A primer on income-related student loan repayment in the United States. Policy Brief: Wisconsin Center for the Advancement of Postsecondary Education. Madison, WI. http://www.wiscape.wisc.edu/wiscape/publications/policy-briefs/pb016

Gross, J. P. K., Ziskin, M. B., Berry, M., \& Hossler, D. (In Press). A longitudinal analysis of the effects of institutional merit-based aid on educational attainment using coarsened exact matching. Review of Higher Education.

Gross, J. P. K., Zerquera, D., Inge, B., \& Berry, M. (In Press). Latino associate degree completion: Effects of financial aid over time. Journal of Hispanic Higher Education.

Bergman, M., Gross, J. P. K., Berry, M., \& Shuck, B. (In Press). If life happened but a degree didn't: Examining factors that impact adult students in a degree completion program. Journal of Continuing Higher Education. 
Bukoski, B. E., Lewis, T., Carptenter, B. W., Berry, M. S., \& Sanders, K. (Revise \& Resubmit) Examining the social justice identity of assistant principals in persistently low-achieving schools.

Gross, J.P.K., \& Berry, M. (Revise \& Resubmit). The effects of state policy levers on student flow in postsecondary education.

Gross, J. P. K., Berry, M. Bell, A. D \& Renner, B. (Revise \& Resubmit). A quasiexperimental analysis of the impact of taking and completing remedial courses on graduation and time to degree at four-year institutions.

Gross, J. P. K., Berry, M., Reynolds, P. R., \& Bell, A. D. (Under review). An analysis of the moderating effects of gender on financial aid and baccalaureate degree completion.

\section{PRESENTATIONS}

Gross, J. P. K., Berry, M. S., \& Hughes, J. Planning for diversity? The inclusion of diversity goals in postsecondary statewide strategic plans. Paper presented at Association for Study of Higher Education Annual Conference (2013, November).

Lewis, T., Bukoski, B. E., Carptenter, B. W., Berry, M. S., \& Sanders, K. The complexities of realizing community: Assistant principals as community leaders in persistently low-achieving schools. Paper presented at University Council for Educational Administration Annual Conference (2013, November).

Carpenter, B. W., Bukoski, B. E., Berry, M. S., \& Mithell, A. (2013, April). Examining the social justice identity of assistant principals in persistently low-achieving schools. Paper presented at 2013 AERA Annual Conference, San Francisco, CA.

Wilson, K. B., Smith, N. L., Berry, M. S. (2012, November). "I was able to complete my associate's degree on my first deployment”: The Espoused Storylines about College Attendance in Army Videos. Paper presented at the 2011 ASHE Annual Conference, Las Vegas, NV.

\section{EXTERNAL FUNDING}

Assisted in overseeing implementation following grant upon receipt:

Gross, J. P. K., \& Hillman, N. Efficiency and fairness in student loan repayment. The Lumina Foundation for Education's New Models of Student Financial Support for \$96,000 from August 2013 to February 2014.

\section{MANUSCRIPTS IN PROGRESS}

Bukoski, B. E., Carroll, T., \& Berry, M. S. (In Progress). "Endlessly incomplete": The role of diversity coursework in practitioners' social justice identity development. 
Bukoski, B. E., Carpenter, B. W. C., Berry, M. S., Inge, B., \& Sanders, K. (In Progress). Examining the social justice identity of academic advisors in a postsecondary college of education.

Gross, J. P. K., Bell, A., Berry, M. S. (In Progress). The relationship between state aid \& educational attainment: An event history analysis of need \& merit-based financial aid.

Gross, J. P. K., Berry, M. S. (In Progress) Planning for diversity? The inclusion of diversity goals in postsecondary statewide strategic plans.

Gross, J. P. K., Bell, A.D., \& Berry, M. (In Progress). The relationship between state aid \& educational attainment: An Event History Analysis of need- \& merit-based financial aid.

Gross, J.P.K., Davidson, C., \& Berry, M. (In Progress). A longitudinal analysis of the effects of KEES and CAP scholarships on educational attainment.

Gross, J. P. K., Bell, A.D., Berry, M. (In Progress). Keeping the PROMISE: Factors affecting timing to merit scholarship loss. Target: Review of Higher Education, March 2014 submission goal.

\section{TEACHING EXPERIENCE}

UNIVERSITY OF LOUISVILLE - LOUISVILLE, KY

Teaching Assistant (Spring 2013) - Legal Issues in Postsecondary Education

- Lead Instructor - Dr. Beth Bukoski

- Graduate Level Course

- Examined historical and current legal issues affecting American Higher Education

Teaching Assistant (Spring 2013) - Leadership, Diversity \& Higher Education

- Lead Instructor - Dr. Beth Bukoski

- Graduate Level Course

- Examined issues of diversity in Higher Education as they pertain to leadership

Teaching Assistant (Fall 2012) - Organization \& Administration of Higher Education Institutions

- Lead Instructor - Dr. Jacob Gross

- Graduate level course

- Examined the organization and structure of higher education

Teaching Assistant (Summer 2012) - Organization \& Administration of Higher Education Institutions

- Lead Instructor - Dr. Jacob Gross

- Online graduate level course

- Examined the organization and structure of higher education 
BENEDICTINE UNIVERSITY - LISLE, IL

Instructor (2011) - Benedictine Beginnings

- Developed and implemented new retention program and course directed toward atrisk first year students

- Taught academic recovery course for at-risk second semester freshman

- Course focused on academic skill building, campus/social integration, and resource knowledge/utilization

\section{PROFESSIONAL EXPERIENCE}

UNIVERSITY OF LOUISVILLE - LOUISVILLE, KY

\section{Research Assistant}

August 2011 - Present

- Assist in development, design, and execution of original research

- Manage other research team members in various aspects of study creation and execution

- Organize and manage large data sets

- Analyze and interpret data using qualitative and quantitative methodological approaches

- Assist in coordination and execution of $\$ 100,000$ grant from the Lumina Foundation

- Collaborate with Kentucky Council on Postsecondary Education to conduct policy research and program evaluation

BENEDICTINE UNIVERSITY - LISLE, IL

\section{Academic Advisor \& Lecturer}

March 2009 - May 2011

- Advised, registered, and counseled incoming freshman and transfer students in all majors

- Responsible for promoting and tracking retention of first year students

- Developed relationships between academic community and new students

- Collaborated with academic units and student affairs to promote new student integration and success

- Led the development, implementation, and assessment of new university seminar for academically at-risk students

BENEDICTINE UNIVERSITY - LISLE, IL

\section{Transfer Admission Counselor}

July 2008 - March 2009

- Record enrollment in territory in both fall of 2008 and spring of 2009 semesters

- Performed credit evaluations for prospective transfer students

- Advised community college students through course selection to ensure a smooth transfer

BENEDICTINE UNIVERSITY - LISLE, IL

Freshman Admission Counselor 
June 2007 - July 2008

- Recruited students from north, west, and northwest Chicago suburbs

- Served simultaneously as admission counselor for the university's two largest instate recruitment territories as well as for all undergraduate and graduate international students

- Developed marketing strategy including the creation of college fair promotional materials

- Record of success in meeting enrollment targets

MIDSTATE EDUCATORS CREDIT UNION - COLUMBUS, OH

Business Development/Marketing Specialist

July 2006-June 2007

- Created mutually beneficial relationships between credit union and Ohio schools

- Developed marketing strategy designed for penetration of area colleges and universities

- Assisted in creation and implementation of financial literacy program for local students

PROFESSIONAL SERVICE

JOURNAL OF STUDENT FINANCIAL AID

Managing Co-Editor

March 2014 - Present

- Review and edit journal submissions

- Recruit submissions for journal through

JOURNAL OF STUDENT FINANCIAL AID

Rising Professional Editorial Board Member

May 2013 - Present

- Selected via national search as one of five graduate to serve on JSFA's editorial board

- Review articles submitted for publication

- Provide training for new journal reviewers

KENTUCKY JOURNAL OF HIGHER EDUCATION POLICY \& PRACTICE Managing Co-Editor

September 2011 - September 2012

- Assisted in creation and launch of open access online academic and practitioner journal

- Reviewed and edited journal submissions

\section{OTHER ACTIVITIES/AFFILIATIONS}

Representative: University of Louisville Graduate Student Council - September 2012 to Present

Tutor: Introduction to Statistics University of Louisville - September 2013 to Present 
Session Chair: Faculty Approaches to Teaching and Learning Session AERA 2013 Conference

Club Advisor: Benedictine University chapter of Rotaract club - March 2009 to May 2011

Member: National Academic Advising Association - March 2009 to May 2011

Member: Illinois Academic Advisors Association - March 2009 to May 2011

Member: Private Illinois Colleges and Universities - July 2008 to March 2009

Member: Illinois Association of College Admission Counselors to July 2007 to March 2009

Member: National Association of College Admission Counselors to July 2007 to March 2009

Outfield /Assistant Hitting Coach: Wittenberg University Men's Varsity Baseball Team $-2007$

Member: Wittenberg University Men's Varsity Baseball Team 2002 to 2006 - All-

Conference selection 2006 